\title{
Advice to reduce dietary salt for prevention of cardiovascular disease (Review)
}

\author{
Hooper L, Bartlett C, Davey Smith G, Ebrahim S
}

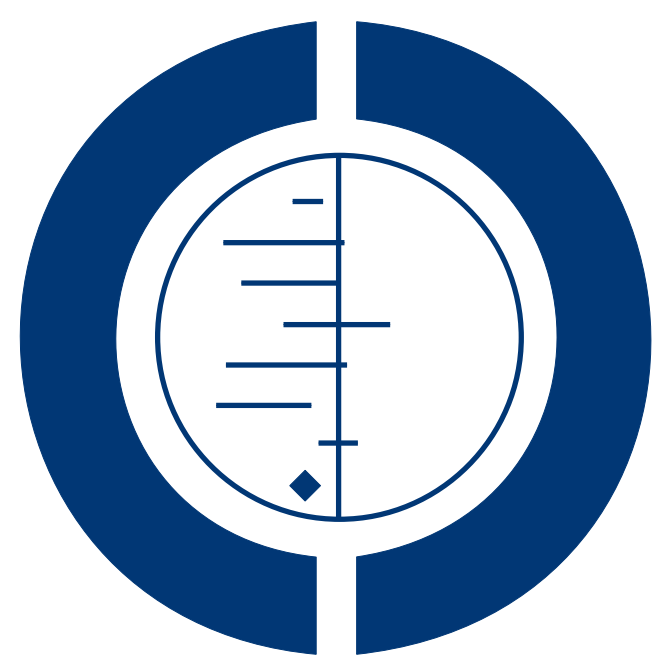

\section{THE COCHRANE COLLABORATION $^{\circledR}$}

This is a reprint of a Cochrane review, prepared and maintained by The Cochrane Collaboration and published in The Cochrane Library 2004, Issue 1

http://www.thecochranelibrary.com

\section{WILEY}


TABLE OF CONTENTS

HEADER . . . . . . . . . . . . . . . . . . . . . . . . . . . . . . . . . . . . . . . . 1

ABSTRACT . . . . . . . . . . . . . . . . . . . . . . . . . . . . . . . . . . . . . . . . . . . . . . . . . . 1

PLAIN LANGUAGE SUMMARY . . . . . . . . . . . . . . . . . . . . . . . . . . . . . . . . . . .

BACKGROUND . . . . . . . . . . . . . . . . . . . . . . . . . . . . . . . . . . . . . 2

OBJECTIVES . . . . . . . . . . . . . . . . . . . . . . . . . . . . . . . . . . . . . . . .

METHODS . . . . . . . . . . . . . . . . . . . . . . . . . . . . . . . . . . . . . .

RESULTS . . . . . . . . . . . . . . . . . . . . . . . . . . . . . . . . . . . . . . . 5

DISCUSSION . . . . . . . . . . . . . . . . . . . . . . . . . . . . . . . . . . . . . 8

AUTHORS' CONCLUSIONS . . . . . . . . . . . . . . . . . . . . . . . . . . . . . . . . . . . . . . . . 10

ACKNOWLEDGEMENTS . . . . . . . . . . . . . . . . . . . . . . . . . . . . . . . . . . 11

REFERENCES . . . . . . . . . . . . . . . . . . . . . . . . . . . . . . . . . . . . . . 11

CHARACTERISTICS OF STUDIES . . . . . . . . . . . . . . . . . . . . . . . . . . . . . . . . .

DATA AND ANALYSES . . . . . . . . . . . . . . . . . . . . . . . . . . . . . . . . . . . . . . . . . . . . . . .

Analysis 1.1. Comparison 1 Mortality and cardiovascular morbidity, Outcome 1 Mortality. . . . . . . . . . . 33

Analysis 1.2. Comparison 1 Mortality and cardiovascular morbidity, Outcome 2 Cardiovascular morbidity. . . . . . 33

Analysis 2.1. Comparison 2 Systolic blood pressure, Outcome 1 Trials with 6 to 12 months of follow up. . . . . 34

Analysis 2.2. Comparison 2 Systolic blood pressure, Outcome 2 Trials with 13 to 60 months of follow up. . . . . . 35

Analysis 2.3. Comparison 2 Systolic blood pressure, Outcome 3 Trials with more than 60 months of follow up. . . . 36

Analysis 3.1. Comparison 3 Diastolic blood pressure, Outcome 1 Trials with 6 to 12 months of follow up. . . . . . 37

Analysis 3.2. Comparison 3 Diastolic blood pressure, Outcome 2 Trials with 13 to 60 months of follow up. . . . . 38

Analysis 3.3. Comparison 3 Diastolic blood pressure, Outcome 3 Trials with more than 60 months of follow up. . . 39

Analysis 4.1. Comparison 4 Urinary sodium excretion, Outcome 1 Urinary sodium excretion at different times following intervention. . . . . . . . . . . . . . . . . . . . . . . . . . . . . . . . . . 40

Analysis 5.1. Comparison 5 Dropouts, Outcome 1 Comparison of dropouts at longest follow up. . . . . . . . . 41

ADDITIONAL TABLES . . . . . . . . . . . . . . . . . . . . . . . . . . . . . . . . . . . . . . . . . . . . .

FEEDBACK . . . . . . . . . . . . . . . . . . . . . . . . . . . . . . . . . . . . . . . . . 53

WHAT'S NEW . . . . . . . . . . . . . . . . . . . . . . . . . . . . . . . . . . . . . . . . . 59

HISTORY . . . . . . . . . . . . . . . . . . . . . . . . . . . . . . . . . . . . . . . . . . . . . 59

CONTRIBUTIONS OF AUTHORS . . . . . . . . . . . . . . . . . . . . . . . . . . . . . . . . . . . . . . . . . . . .

DECLARATIONS OF INTEREST . . . . . . . . . . . . . . . . . . . . . . . . . . . . . . . . . . . . . 60

SOURCES OF SUPPORT . . . . . . . . . . . . . . . . . . . . . . . . . . . . . . . . . . 60

INDEX TERMS . . . . . . . . . . . . . . . . . . . . . . . . . . . . . . . . . . . . . . . . . . . . . . . 60

Advice to reduce dietary salt for prevention of cardiovascular disease (Review)

Copyright $\odot 2009$ The Cochrane Collaboration. Published by John Wiley \& Sons, Ltd. 


\title{
[Intervention Review]
}

\section{Advice to reduce dietary salt for prevention of cardiovascular disease}

\author{
Lee Hooper ${ }^{1}$, Christopher Bartlett ${ }^{2}$, George Davey Smith $^{3}$, Shah Ebrahim ${ }^{4}$ \\ ${ }^{1}$ School of Medicine, Health Policy \& Practice, University of East Anglia, Norwich, UK. ${ }^{2}$ Swindon Primary Care Trust, North Swindon \\ District Centre, Swindon, UK. ${ }^{3}$ Department of Social Medicine, University of Bristol, Bristol, UK. ${ }^{4}$ Department of Epidemiology \& \\ Population Health, London School of Hygiene \& Tropical Medicine, London, UK
}

Contact address: Lee Hooper, School of Medicine, Health Policy \& Practice, University of East Anglia, Norwich, NR4 7TJ, UK. 1.hooper@uea.ac.uk.

Editorial group: Cochrane Hypertension Group.

Publication status and date: Edited (no change to conclusions), published in Issue 1, 2009.

Review content assessed as up-to-date: 25 November 2003.

Citation: Hooper L, Bartlett C, Davey Smith G, Ebrahim S. Advice to reduce dietary salt for prevention of cardiovascular disease. Cochrane Database of Systematic Reviews 2004, Issue 1. Art. No.: CD003656. DOI: 10.1002/14651858.CD003656.pub2.

Copyright (C) 2009 The Cochrane Collaboration. Published by John Wiley \& Sons, Ltd.

\begin{abstract}
A B S T R A C T
Background

Restricting sodium intake in hypertensive patients over short periods of time reduces blood pressure. Long term effects (on mortality,
\end{abstract} morbidity or blood pressure) of advice to reduce salt in patients with elevated or normal blood pressure are unclear.

\section{Objectives}

To assess in adults the long term effects (mortality, cardiovascular events, blood pressure, quality of life, weight, urinary sodium excretion, other nutrients and use of anti-hypertensive medications) of advice to restrict dietary sodium using all relevant randomised controlled trials.

\section{Search methods}

The Cochrane Library, MEDLINE, EMBASE, bibliographies of included studies and related systematic reviews were searched for unconfounded randomised trials in healthy adults aiming to reduce sodium intake over at least 6 months. Attempts were made to trace unpublished or missed studies and authors of all included trials were contacted. There were no language restrictions.

\section{Selection criteria}

Inclusion decisions were independently duplicated and based on the following criteria: 1) randomisation was adequate; 2) there was a usual or control diet group; 3) the intervention aimed to reduce sodium intake; 4) the intervention was not multifactorial; 5) the participants were not children, acutely ill, pregnant or institutionalised; 6) follow-up was at least 26 weeks; 7) data on any of the outcomes of interest were available.

\section{Data collection and analysis}

Decisions on validity and data extraction were made independently by two reviewers, disagreements were resolved by discussion or if necessary by a third reviewer. Random effects meta-analysis, sub-grouping, sensitivity analysis and meta-regression were performed.

Advice to reduce dietary salt for prevention of cardiovascular disease (Review)

Copyright $\odot 2009$ The Cochrane Collaboration. Published by John Wiley \& Sons, Ltd.

\section{.}




\section{Main results}

Three trials in normotensives $(\mathrm{n}=2326)$, five in untreated hypertensives $(\mathrm{n}=387)$ and three in treated hypertensives ( $\mathrm{n}=801)$ were included, with follow up from six months to seven years. The large, high quality (and therefore most informative) studies used intensive behavioural interventions.

Deaths and cardiovascular events were inconsistently defined and reported; only 17 deaths equally distributed between intervention and control groups occurred. Systolic and diastolic blood pressures were reduced at 13 to 60 months in those given low sodium advice as compared with controls (systolic by $1.1 \mathrm{~mm} \mathrm{Hg}$, 95\% CI 1.8 to 0.4 , diastolic by $0.6 \mathrm{~mm} \mathrm{hg,} 95 \%$ CI 1.5 to -0.3 ), as was urinary 24 hour sodium excretion (by $35.5 \mathrm{mmol} / 24$ hours, $95 \%$ CI 47.2 to 23.9). Degree of reduction in sodium intake and change in blood pressure were not related. People on anti-hypertensive medications were able to stop their medication more often on a reduced sodium diet as compared with controls, while maintaining similar blood pressure control.

\section{Authors' conclusions}

Intensive interventions, unsuited to primary care or population prevention programmes, provide only minimal reductions in blood pressure during long-term trials. Further evaluations to assess effects on morbidity and mortality outcomes are needed for populations as a whole and for patients with elevated blood pressure.

A low sodium diet may help in maintenance of lower blood pressure following withdrawal of antihypertensives. If this is confirmed, with no increase in cardiovascular events, then targeting of comprehensive dietary and behavioural programmes in patients with elevated blood pressure requiring drug treatment would be justified.

\section{PLAIN LANGUAGE SUMMARY}

\section{The long term effects of advice to cut down on salt in food on deaths, cardiovascular disease and blood pressure in adults}

Intensive support and encouragement to reduce salt intake did lead to reduction in salt eaten. It also lowered blood pressure but only by a small amount (about $1 \mathrm{mmHg}$ for systolic blood pressure, less for diastolic) after more than a year. This reduction was not enough to expect an important health benefit. It was also very hard to keep to a low salt diet. However, the reduction in blood pressure appeared larger for people with higher blood pressure.

There was not enough information to assess the effect of these changes in salt intake on health or deaths.

Evidence from a large and small trial showed that advice to reduce salt helps to maintain lower blood pressure following withdrawal of antihypertensive medication. If this is confirmed, with no increase in cardiovascular events, then comprehensive dietary and behavioural programmes in patients with elevated blood pressure requiring drug treatment would be justified.

See also the Cochrane review of short-term salt reduction trials: Jurgens 2003.

\section{B A C K G R O U N D}

There is evidence from published systematic reviews that restricting sodium intake in people with elevated blood pressure leads to reductions in blood pressure of about $4 \mathrm{~mm}$ hg systolic and 2 mm hg diastolic (Law 1991; Midgley 1996; Cutler 1997; Graudal 1998; Alam 1999; Jurgens 2003). However, within these reviews many included trials are short term, neither allowing for complete adjustment of blood pressure to altered sodium intake or to reduced motivation for following dietary restrictions over time. Also, some trials increased sodium intake in one arm and compared this with a reduced sodium intake in the other arm and so do not estimate likely effects of cutting down on sodium in a normal diet. In addition, some reviews suggest that the level of blood pressure reduction achieved over a longer period in free-living adults is less impressive than in the short term (Ebrahim 1996; Ebrahim 1998; Graudal 1998).

A decrease in blood pressure is only important if it results in a 
decrease in cardiovascular events and deaths. The published systematic reviews on the effect of salt restriction on blood pressure and other risk factor outcomes have expressed different interpretations with regard to the significance of these changes in relation to cardiovascular events and deaths. This systematic review and meta-analysis aimed to draw together information on the effect of long-term dietary salt reduction on health outcomes.

\section{O B J E C T I V E S}

This systematic review aimed to study the effects of restricting sodium intake over at least six months in free-living adults, compared with a normal or usual sodium intake.

The specific objectives were to assess, in people with normal and elevated blood pressure, the effect of advice and/or support to reduce dietary sodium intake, on deaths and cardiovascular events; number and dose of anti-hypertensive medications used; quality of life; weight; systolic and diastolic blood pressure; and urinary sodium excretion and other nutrient intakes in free-living adults at least six months after the initial intervention was commenced.

The effects of potential modifiers of salt restriction (i.e. initial level of blood pressure, categorization into normal or elevated blood pressure, degree of sodium reduction, gender, race and age) were also investigated.

\section{METHODS}

\section{Criteria for considering studies for this review}

\section{Types of studies}

All randomised controlled clinical trials (randomisation of individuals, or into at least six clusters) with at least 26 weeks of follow up from initiation of intervention.

\section{Types of participants}

Studies of adults (16 years or older) with normal or raised blood pressure were accepted. Participants were of either gender, but those institutionalised, acutely ill or pregnant were excluded.

\section{Types of interventions}

The interventions included were designed to reduce sodium intake. The control group received a placebo intervention or no active intervention. Studies were not included if they used a multiple risk factor intervention intending to alter lifestyle or dietary factors other than sodium (unless the effect of the low sodium diet could be separated out from the other interventions). For example, interventions that aimed to reduce sodium and increase potassium were excluded, whilst in factorial interventions aiming to reduce sodium intake and reduce weight, the low sodium arm (without weight intervention) was compared to the control group (without sodium or weight interventions).

\section{Types of outcome measures}

\section{Primary outcomes:}

The main outcomes were total mortality and combined cardiovascular events (including fatal and non-fatal myocardial infarction, stroke, angina, heart failure, peripheral vascular events, sudden death and non-scheduled cardiovascular interventions - coronary artery bypass surgery or angioplasty). Both of these outcomes were examined as relative risk in the intervention vs control group at the latest time point available.

\section{Secondary outcomes:}

Changes in systolic and diastolic blood pressure $(\mathrm{mm} \mathrm{Hg})$, quality of life, weight $(\mathrm{kg})$, nutrient intakes, urinary sodium excretion (mmol/24 hours) and numbers and doses of anti-hypertensive medication used. These were assessed at intermediate ( 6 months to and including 12 months), late (13 to 60 months) and very late follow up (over 60 months).

\section{Search methods for identification of studies}

Two searches were conducted, titles and abstracts scanned and papers retrieved independently of each other. For the first search (LH) the results of a previous large-scale search (Hooper 2000) for dietary trials were used. This search scanned for trials on any dietary intervention and cardiovascular disease and included searching of the Cochrane Library, MEDLINE, EMBASE, CAB Abstracts, CVRCT registry, SIGLE to May 1998 plus bibliographies of collected papers and reviews. It was updated for this review by searching for systematic reviews or randomised controlled trials on sodium manipulation and blood pressure in The Cochrane Library and MEDLINE (using randomised controlled trial filters): DIET-SODIUM-RESTRICTED*:ME

SODIUM-DIETARY*:ME

(DIET* near (SALT* or SODIUM*))

((\#1 or \#2) or \#3)

HYPERTENSION*:ME

HYPERTENS*

(\#5 or \#6)

(\#4 and \#7)

The second search (CB) looked specifically for trials on salt or sodium restriction and blood pressure, and was run on MEDLINE, EMBASE and The Cochrane Library. The Cochrane search strategy (below) was used in conjunction with special search filters to find randomised controlled trials on MEDLINE and EMBASE. HYPERTENS* 


\author{
HYPERTENSION*:ME \\ (BLOOD near PRESSURE) \\ ((\#1 or \#2) or \#3) \\ DIET-SODIUM-RESTRICTED*:ME \\ SODIUM-CHLORIDE*:ME \\ (DIET* near ((SALT or SODIUM) or CHANGE)) \\ (DIET* near (THERAPY or INTERVENTION)) \\ (RESTRICT* near (SALT or SODIUM)) \\ (LOWER* near (SALT or SODIUM)) \\ (INTAKE* near (SALT or SODIUM)) \\ (REDUC* near (SALT or SODIUM)) \\ $((((((\# 5$ or \#6) or \#7) or \#8) or \#9) or \#10) or \#11) or \#12) \\ (\#4 and \#13)
}

Neither search was limited by language. Systematic reviews on dietary sodium and blood pressure were retrieved and bibliographies of these and included studies scanned for further trials of at least six months duration. Attempts were made to contact authors of all included studies for details of further relevant trials that may have been missed (either published or unpublished).

\section{Data collection and analysis}

Two reviewers (LH, CB) independently screened each article or trial report with regard to the inclusion criteria. Articles were only rejected on initial screen if the reviewer could determine from the title and abstract that the article was not a report of a randomised controlled trial; or the trial did not address a low sodium diet, or the trial was exclusively in children less than 16 years old, pregnant women or the critically ill; or the control group was not on usual diet or placebo intervention; or the trial was of less than six months duration; or the intervention was multi-factorial. When a title or abstract could not be rejected with certainty the full text of the article was obtained for further evaluation.

Data extraction and quality assessment were performed independently by two reviewers (CB, LH) onto forms designed for the review (except for data on weight and other nutrients, which were extracted by LH only). Disagreements were resolved by discussion or if necessary by a third reviewer (SE).

Data extraction included details on population characteristics, intervention and control procedures and outcomes of interest. Mortality and cardiovascular event data were collected as events per number of participants randomised to control and intervention groups. Change in blood pressure, weight, other nutrient intakes and sodium excretion from baseline to assessment period were collected as continuous variables - number of subjects, mean change in the outcome variable and standard deviation of the change for both intervention and control groups. Data were collected on systolic and diastolic blood pressure changes, and urinary sodium excretion, at intermediate (latest data point available from 6 to 12 months), late (latest data point available between 13 and 60 months) and very late (after 60 months) follow up.
Four trials (Costa 1981; Arroll 1995; Alli 1992; Morgan 1987) provided baseline and follow-up values, with standard deviation or standard errors, but no standard deviation for the change from baseline. Using all of the three studies (Morgan 1978; TOHP phase I; TOHP phase II) in which data were provided at baseline, follow-up and mean differences given, values for the correlations between baseline and change values (for the control and experimental groups for systolic and diastolic blood pressure values but not for urinary sodium excretion) were computed (Follman 1992). A conservative estimate (lowest correlation) was used to compute the standard deviation for the mean change for four studies (only two of these were used in the meta-analyses). Correlations varied ( 0.11 to 0.47 for systolic blood pressure in control groups, 0.07 to 0.56 for systolic blood pressure in experimental groups, -5.79 to 0.17 for diastolic blood pressure in control groups and -5.22 to 0.19 for diastolic blood pressure in experimental groups). The negative correlations for diastolic blood pressure were due to extremely narrow ranges of diastolic blood pressure at baseline, resulting in very small standard deviations, so that the assumption that standard deviations at trial end would be similar were invalid. For this reason calculated standard deviations were used only for systolic blood pressure.

In factorial trials of calorie and sodium reduction only data from the sodium reduction and control groups were used as, of three such factorial trials (TOHP phase II; HPT; TONE), one reported statistically significant interactions between the two interventions ( TOHP phase II), and another reported a 'suggestion of diminished effect on blood pressure when sodium and calorie counseling were combined' (although this effect was not statistically significant) (HPT). The exception was within the TONE trial, where data on urinary sodium excretion were only available for the combined groups, but where included event and medication data excluded participants on calorie reduction interventions.

Quality assessment included information on randomisation procedure, allocation concealment, blinding of participants, providers of care and outcome assessors and losses to follow up (Anonymous 2000). Where those recruiting participants into a trial appeared unaware of the treatment allocation of those participants until after recruitment was complete and where it was not possible to alter allocation after treatment was assigned allocation concealment was judged 'adequate'. Other possibilities were 'inadequate' or 'unclear'. Blinding of participants to their assigned treatment was not possible, awareness of outcome assessors to the recipients assigned treatment was judged 'no' (equivalent to 'blinded'), 'yes', or 'unclear'. Numbers of participants lost to follow-up in each arm were noted, as was the method used in the data analysis to adjust for these losses.

Disagreements in data extraction or quality assessment were discussed and referred to another reviewer (SE) where necessary. Attempts were made to contact all authors of included studies for further information on trial characteristics, quality and outcomes 
(where further information was not available numbers were extracted from available published figures and graphs).

\section{Quantitative data synthesis}

Primary measures of interest were the effects of dietary advice to reduce sodium intake on

1. total mortality and

2. cardiovascular events and interventions.

For mortality and cardiovascular events, relative risks were used to examine differences between low sodium and control groups using the random effects model. For continuous outcomes, weighted mean differences were examined, again using the random effects model, on Cochrane Collaboration Review Manager 4.1 software. Meta-analyses were checked for heterogeneity by visual inspection and by Cochran's test.

Two trials were identified as being cluster randomised. In one small trial, Alli 1992, 19 general practitioners were randomised to deliver simple low salt advice or no advice to a total of 77 patients. Patient numbers in the intervention and control groups were reduced to an effective sample size as described by Hauck 1991, assuming the intraclass correlation (appropriate for nonfamilial clusters such as randomised practice units) to be 0.5 (Donner 1982). The other cluster randomised trial was Thaler (which consisted of one publication, but the unpublished data provided were separated into data for men, referred to as Thaler men 1982 and data for women, Thaler women 1982). Individually randomised 'index' men and women included members of their families in the trial. Only the 'index' participants were used in this meta-analysis.

Random effects meta-regression (Berkley 1995) was used to assess the effect of initial level of systolic blood pressure, degree of sodium reduction achieved, percentage female participants, percentage white participants and initial mean age on systolic blood pressure (there were insufficient data on the primary endpoints, death or cardiovascular events to make meta-regression on these endpoints meaningful). Metaregression was performed using the STATA command metareg (Sharp 1998).

Sensitivity analysis was carried out to assess the robustness of the results to a) the exclusion of the data for which standard deviation of the change was imputed, b) use of the largest correlations to estimate these standard deviations, c) the exclusion of trials with unknown or inadequate allocation concealment (Anonymous 2000) and d) inclusion of the weight and salt reduction arms of factorial trials (where data for the appropriate [weight loss + low sodium] vs [weight loss] comparison were added to a meta-analysis plot beside the already included [low sodium] vs [control] comparison).

\section{RES U L T S}

\section{Description of studies}

See: Characteristics of included studies; Characteristics of excluded studies.

The 11 studies included within the review are described in the table 'characteristics of included studies'. The number of publications assessed to come to these 11 studies and the outcomes that were available in the 11 studies are shown in the Quorom Flow Diagram which can be seen at this website: http://www.ti.ubc.ca/ PDF/A019QFD.pdf

Three trials in normotensives $(n=2326$, HPT; TOHP phase I; TOHP phase II), five in untreated hypertensives ( $n=387$, Morgan 1978; Costa 1981; Thaler (Thaler men 1982; Thaler women 1982); Silman 1983; Alli 1992) and three in treated hypertensives ( $n=801$, Morgan 1987; Arroll 1995; TONE) were included, with follow up from six months to seven years.

The three normotensive trials were in healthy people (predominantly white, male, mean age 40) with high normal blood pressure. Entry criteria varied between trials, but included those with diastolic blood pressure from 78 to $89 \mathrm{~mm} \mathrm{hg}$, with a narrow range of means from 83 to $86 \mathrm{~mm}$ hg diastolic and 124 to 127 $\mathrm{mm}$ hg systolic. All of the studies were conducted in the USA and included from 392 to 1190 randomised participants.

All three studies (as well as TONE, below) ran comprehensive dietary and behaviour change programmes led by experienced personnel, including group counseling sessions, regularly over several months, with newsletters between sessions, self assessment, goal setting, food tasting and recipes. Control groups received no active intervention. Sodium excretion goals were set at $70-80 \mathrm{mmol} /$ 24 hours. For example, the HPT study ran ten weekly group counseling sessions on food selection, food preparation and behaviour management skills, followed by semi-monthly and then bi-monthly meetings throughout the trial (with newsletters in the months where no meetings occurred). Sessions were run by nutritionists and behavioural scientists and individual counseling was provided where participants missed sessions or had special needs. Techniques used in the sessions included group discussions, instructions for dietary record keeping, goal setting, individual diet analysis for each participant, cooking demonstrations, provision of recipe books and tasting of new foods.

The five trials in untreated hypertensives included people from 16 to 64 years, were carried out in Australia, New Zealand, Italy and the UK and ranged in size from 28 to 164 participants. Entry criteria ranged from unspecified 'untreated borderline hypertension' (Costa 1981), diastolic blood pressure ranges within 90 to 109 mm hg (Morgan 1978; Silman 1983; Alli 1992) and systolic blood pressure $137-180 \mathrm{~mm}$ hg (Thaler 1982). 42 to $100 \%$ of participants were male (not specified in two trials, Costa 1981; Silman 1983) and no trial described the ethnicity of its participants. Interventions in the studies on untreated hypertensives included:

- individual counseling and a leaflet provided by a general practitioner with reinforcement at each clinic visit, while the control group maintained their usual diet (Alli 1992),

- a salt restriction programme for the whole family led by a 
nutritionist including a cookbook and individual counseling (some at the family home) with provision of low sodium baking powder and baking soda and low sodium bread provided weekly by a local baker, while the control group were asked to eat their usual diet (Thaler 1982),

- a general health education package (on healthy eating, smoking, exercise and stress control) with teaching about a low fat diet (diet sheet provided) compared with the general health education package only in the control group (Silman 1983),

- given a low salt diet (no details provided) compared with advice on a diet with free salt in the control group (Costa 1981),

- instructions to reduce dietary sodium chloride intake, with advice repeated at 3 months (no further details provided) compared with no intervention in the control group (Morgan 1978).

Sodium goals varied from $<80 \mathrm{mmol} / 24$ hours to $<100 \mathrm{mmol} / 24$ hours of urinary sodium excretion, $3 \mathrm{~g} \mathrm{NaCl}$ per day and 70-100 $\mathrm{mmol} / 24$ hours of sodium intake.

The three trials in treated hypertensives had mean ages of 55 to 67 years, were carried out in Australia, New Zealand and the USA and ranged in size from 20 to 641 participants. Entry criteria varied, diastolic blood pressure was 70-105 $\mathrm{mm}$ hg or systolic blood pressure 155-180 $\mathrm{mm}$ hg while taking antihypertensive treatment (Arroll 1995), diastolic blood pressure $<85 \mathrm{~mm}$ hg while taking antihypertensive treatment and $>100 \mathrm{~mm}$ hg without treatment (Morgan 1987) or $<85 \mathrm{~mm}$ hg diastolic and $<145 \mathrm{~mm}$ hg systolic blood pressure while taking antihypertensive medication (TONE). $49-100 \%$ of participants were male and $76 \%$ were white in the TONE study (ethnicity was not mentioned in the other studies).

Interventions in trials of treated hypertensives included:

- being asked to reduce use of high salt foods, salt at table and in cooking, given an article on blood pressure and salt restriction, a leaflet and a book with sodium contents of common foods, compared with no intervention in the control group (Arroll 1995),

- a low sodium diet (no further details provided) compared with a normal diet in the control group (Morgan 1987), and

- an individual nutrition and behavioural counseling programme (as above) or no such programme but with invitations to meetings on unrelated topics in the control group (TONE).

Sodium goals were dietary intake of $50-75 \mathrm{mmol} / 24$ hours (Morgan 1987), urinary sodium $<80 \mathrm{mmol} / 24$ hours (TONE) and unspecified (Arroll 1995).

Excluded studies (where the full text paper was collected) were excluded on the basis of no follow up after six or more months (28 studies), having a multifactorial intervention where the effects of salt reduction advice could not be separated from other interventions (17 studies), lack of randomisation (10 studies), lack of an appropriate 'usual diet' control group (10 studies) or inclusion of children (one study). Studies were often excluded for several reasons, but one main reason has been provided for each study in the list above.

\section{Risk of bias in included studies}

Trial quality as judged by allocation concealment appeared higher in the trials on normotensives (allocation concealment adequate in three of three trials, compared to one of three trials in treated hypertensives and zero of five trials in untreated hypertensives). Other aspects of trial quality assessed included blinding of outcome assessment and losses to follow up. Different methods of dealing with missing data associated with losses to follow up were apparent. The majority of trials attempted to blind outcome assessors. For further details of individual study quality see the 'Notes' section of the Table of Characteristics of Included Studies.

\section{Effects of interventions}

\section{Mortality and cardiovascular events}

These outcomes were inconsistently reported in trials (see Table 1). No differences in periods of hospitalisation were seen between intervention groups in the HPT study (no further data were provided). Morgan 1978 reported that three control participants were treated for cardiac failure, as were two on low sodium diets, with four cardiovascular deaths in the low sodium group and two in the control group. TONE recorded cardiovascular events (including stroke, transient ischaemic attack, myocardial infarction, angina, congestive heart failure, arrhythmia and 'other' events) of participants. Cardiovascular events occurred in 46 control participants and 36 of those on low sodium diets. Pooling the two studies suggests no significant difference in cardiovascular morbidity between low sodium and control groups (relative risk 0.82, 95\% CI 0.56 to 1.21 ).

The trials report few deaths, altogether only 9 deaths in control groups and 8 in low sodium groups (relative risk 0.90, 95\% CI 0.36 to 2.24 ). The available data are shown in metaview.

\section{Blood pressure}

Changes in blood pressure and urinary sodium excretion at intermediate and late assessments are given in Table 2 and metaanalysis results in Table 3. Systolic blood pressure was reduced on a low salt diet at both intermediate (by $2.5 \mathrm{~mm} \mathrm{hg}, 95 \%$ CI 3.8 to 1.2 ) and late follow up (by $1.1 \mathrm{~mm} \mathrm{hg}, 95 \%$ CI 1.8 to 0.4 ). Diastolic blood pressure was also reduced at intermediate follow up (by $1.2 \mathrm{~mm} \mathrm{hg,} \mathrm{95 \%} \mathrm{CI} 1.8$ to 0.6 ), less so later (by $0.6 \mathrm{~mm}$ hg, 1.5 to -0.3$)$.

The few participants with very late follow up (seven years) had non-significant reductions in systolic (by $3.8 \mathrm{~mm} \mathrm{hg}, 95 \% \mathrm{CI}$ 7.9 to -0.3 ) and diastolic (by $2.2 \mathrm{~mm} \mathrm{hg,} 95 \%$ CI 4.8 to -0.4 ) blood pressure. It should be noted that this late follow up of the TOHP phase I study was technically after the end of the trial. 
TOHP phase I ran for 18 months with a consistent intervention to help the low sodium group stick to a low sodium diet. The 7year results are described as 'posttrial' results, and as 7 years follow up, and the trialists implied that they were assessing the long term effect of their 18 month intervention. We (as reviewers) felt that if the trial just stopped intervening, without altering the diets of either the intervention or control groups then we could include data from the later follow up (in many studies the intervention only happens once or twice at the beginning, but the effect is measured months later). The paper states that 'after 18-months, there was no further contact with the trial participants to enhance the intervention effect'. We could not contact the reviewers to confirm that there were no suggested alterations to the diets of the participants after the eighteen month intervention, so the data are included here but with this note of caution.

Statistical heterogeneity was present for systolic blood pressure at intermediate follow up and diastolic blood pressure at late follow up, but was resolved when sensitivity analyses removed trials with inadequate or unclear allocation concealment, or with imputed standard deviations, or when trials were sub-grouped into normotensive or hypertensive at baseline.

Sensitivity analysis, excluding trials with inadequate allocation concealment, resulted in all trials on untreated hypertensives being removed. As these trials were small, the effect on pooled estimates of blood pressure change was minor. Adding in data for the weight reduction arms of factorial trials strongly reduced the effect of low sodium advice on blood pressure, and slightly reduced the effect on sodium excretion (Table 3).

Meta-regression of blood pressure change up to 12 months using all trials with relevant data (or trials with adequate allocation concealment, effectively trials on normotensives) showed no relationship with change in urinary sodium excretion, baseline systolic blood pressure or age (Table 4). However, the meta-analyses subgrouping by 'normotensive' or 'hypertensive' participants at baseline did suggest a consistently greater effects of salt restriction on blood pressure in hypertensives. Insufficient data were available of effects on specific races or genders to enable statistical exploration of these factors.

\section{Quality of Life}

Information on quality of life was patchy, with no common outcome measures. HPT asked participants whether they were having problems with their diets. $69 \%$ of those in the low sodium group reported problems at some time during the 3 years of the trial, and problems were reported at $42 \%$ of clinic visits. Problems related to the diet being inconvenient, conflicting with schedules, lack of time for planning, and difficulty in adherence while eating out.

TOHP phase I reported psychological well-being scores. These improved significantly in participants in the low sodium groups at 18 months compared with the non-intervention control group $(\mathrm{p}<0.01)$. It was stated that the improvement was generally consistent across race and sex subgroups but no further information was provided.
Thaler (Thaler men 1982; Thaler women 1982) reported that stopping adding salt at table was not difficult for participants, but many found cutting down on salt in cooking harder. The majority found their low salt bread (salt cut from $2.1 \%$ to $1.0 \%$ dry weight) and salt-free butter acceptable. Only $13 \%$ of participants reported their salt restricted diet as unpleasant or worse.

TONE found that the most common non-cardiovascular event recorded was headache: the low sodium group had a significant reduction in headaches as compared to the control group.

Thaler (Thaler men 1982; Thaler women 1982) asked about presence or absence of muscle cramps in control and low sodium participants. At eight months 13\% of control subjects reported getting cramps a lot or sometimes (as opposed to occasionally or never) whilst this outcome was reported in $30 \%$ of the low sodium group.

Overall drop out rates were very similar (relative risk 1.04, 95\% CI 0.86 to 1.25 ) in low sodium compared with control groups.

\section{Weight}

The suggestion from food diaries in HPT was that men on a low sodium diet take in roughly $240 \mathrm{kcal}$ less per day than their control counterparts. Women on low sodium diets take in 120 fewer kcal per day. This did not result in a large difference in weight; at 3 years those in the control group had gained about $1 \mathrm{~kg}$ on average more than those in the low sodium group.

TOHP phase I observed significantly greater weight loss in the low sodium group compared with control at six $(1.2 \mathrm{~kg})$ and twelve $(0.8 \mathrm{~kg})$ months, but the difference at 18 months $(0.4 \mathrm{~kg})$ was no longer significant. Similarly, in TOHP phase II those on a low sodium diet lost more weight initially $(1.2 \mathrm{~kg}$ difference at 6 months, $\mathrm{p}<0.001$ ), but the difference had disappeared by 36 months.

Arroll 1995 found a weight loss of $1.4 \mathrm{~kg}$ in the low sodium group relative to the controls at six months. However, Morgan 1987, Thaler (Thaler men 1982; Thaler women 1982), and Silman 1983 , found no change in weight in either control or low sodium groups.

In TONE eight participants not assigned to a weight loss intervention experienced excessive weight loss, but it is not clear how many of these were in the control or low sodium groups.

Overall, in the larger studies, where one is more likely to see any real effect, there appeared to be initial weight reductions accompanying the low sodium diet, but the effect was lost over several years.

\section{Urinary sodium excretion}

Meta-analysis demonstrated a reduction in urinary 24 hour sodium excretion at intermediate $(48.9 \mathrm{mmol} / 24$ hours, $95 \% \mathrm{CI}$ 65.4 to 32.5$)$, and late follow up $(35.5 \mathrm{mmol} / 24$ hours, $95 \% \mathrm{CI}$ 47.2 to 23.9) in those advised to follow a low sodium diet compared with control. Significant heterogeneity was seen in results at intermediate and late assessment, and was not resolved by sensitivity analysis leaving out trials with unclear or inadequate allocation concealment. The one trial to assess very late outcomes (TOHP phase $\mathrm{I}$, in normotensives) found that at seven years sodium ex- 
cretion in a small subset of their original sample was similar in intervention and control groups.

\section{Other nutrients}

The relationship between low sodium dietary advice and other dietary components has not been fully explored in these studies. Potassium is the most reported component, usually measured as urinary excretion alongside sodium. Other nutrients were measured as dietary intakes using food record and recall systems.

Minerals

Potassium. In HPT potassium excretion was consistently greater in low sodium than control groups (about $6 \mathrm{mmol} / 24$ hours at 3 years) but whether this difference was statistically significant is not clear. In TONE potassium intake was also greater in the low sodium group than in control (by $160 \mathrm{mg} / 24$ hours, $95 \% \mathrm{CI}$ 25 to 295). The rest of the trials found no significant differences in reported intakes or excretion of potassium including: TOHP phase I, TOHP phase II, Thaler men 1982, Thaler women 1982, Morgan 1978, Morgan 1987 and Silman 1983.

Magnesium. TONE found a higher intake of magnesium in low salt as compared with control groups (by $24 \mathrm{mg} / 24$ hour, $95 \%$ CI 8 to 39), whereas TOHP phase I reported no significant difference between groups.

Calcium. TONE found a significant fall in calcium intake in the low salt as compared with the control group (of $71 \mathrm{mg} / 24$ hours, $95 \%$ CI 119 to 23). HPT found a reduction in salt from dairy foods (suggested in all groups, but only significant in normal weight men), while TOHP phase I reported no significant net differences in reported intake of calcium.

Iron. TOHP phase I reported lower intakes of iron $(3.6 \mathrm{mg} /$ day at 18 months) in the low sodium group. The differences in iron were due to differences in men (women were similar between low sodium and control groups) and the reported iron intakes (15 mg/ day at 18 months in men) in the low sodium group were still well over the RDA (10 mg/day for men). TONE also found lower iron intakes in the low sodium group (lower by $2.8 \mathrm{mg} / 24$ hours, $95 \%$ CI 3.8 to 1.8 ).

Phosphorus and zinc were not significantly different in low sodium and control groups in TONE.

Vitamins

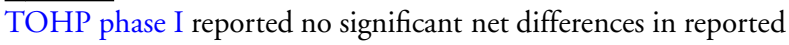
intakes of vitamin $\mathrm{A}$, vitamin $\mathrm{C}$, thiamine, riboflavin or niacin. TONE found lower intakes of thiamine $(0.12 \mathrm{mg} / 24$ hours, $95 \%$ CI 0.22 to 0.02$)$ and riboflavin $(0.2 \mathrm{mg} / 24$ hours, $95 \%$ CI 0.3 to 0.1 ) in low sodium groups, but no significant differences in vitamins A, Bs, C, D, E, folate or niacin (excluding supplements). Macronutrients

Energy. TOHP phase I reported significantly lower daily intakes of total energy $(207 \mathrm{kcal})$ in the low sodium group, as did TONE (by $119 \mathrm{kcal} / 24$ hours, 95\% CI 197 to 41 ).

Fats. Lower intakes of total fat (by $5.8 \mathrm{~g} / 24$ hours, $95 \%$ CI 10.1 to 1.5 ), saturated fat (by $2.4 \mathrm{~g} / 24$ hours, $95 \% \mathrm{CI} 4.0$ to 0.8 ) and monounsaturated fat (by $2.2 \mathrm{~g} / 24$ hours, $95 \%$ CI 4.0 to 0.4 ) were seen in the low sodium group of TONE. No significant differences were seen in polyunsaturated fat intake. TOHP phase I reported significantly lower daily intakes of total fat $(11.4 \mathrm{~g})$ in the low sodium group, but no significant net differences in saturated fat. Alcohol. TOHP phase II reported that there were no differences between the low sodium and usual care groups in alcohol intake, while Arroll 1995 reported an increased intake of alcohol in the control group ( $2.4 \mathrm{~g} /$ day), though it was not clear whether this was statistically significant. TOHP phase I reported no significant net differences in reported intake of alcohol.

Protein and carbohydrates were not significantly different in the low sodium and control groups in TONE.

Overall, there is a trend towards increases in potassium and magnesium, and a fall in calcium, iron, some B vitamins, total energy, total and saturated fats in low sodium groups.

\section{Anti-hypertensive medications used}

Two trials in patients with elevated blood pressure considered the ability of low salt diets to maintain blood pressure control after stopping anti-hypertensive medication. In the smaller trial (Morgan 1987) anti-hypertensive therapy was stopped two months after randomisation to usual or low sodium diet, but restarted if diastolic blood pressure rose. After six months, four of ten men on low sodium diet were taking anti-hypertensive medication, compared to nine of ten on usual diet (relative risk 0.44 , $95 \%$ CI 0.20 to 0.98$)$.

In the larger study (TONE, 975 participants, including those on weight reduction interventions) withdrawal of medication was attempted 3 months after randomisation to low sodium diet (with behavioural therapy) or usual care. The primary combined endpoint (a combination of high blood pressure at any visit, restarting of anti-hypertensive medication or any clinical cardiovascular event) was less common in the low sodium group, relative risk 0.83 (95\% CI 0.75 to 0.92 ), ARR 14\%, NNT 7.

\section{DISCUSSION}

Eleven long term randomised controlled trials of dietary salt reduction (including 3514 participants) provided few data on mortality (17 deaths in total), cardiovascular events or quality of life, but did demonstrate a significant decrease in systolic blood pressure (1.1 mm hg, 95\% CI 1.8 to 0.4 ) and urinary sodium excretion ( $35.5 \mathrm{mmol} / 24$ hours, $95 \% \mathrm{CI} 47.2$ to 23.9 ) at 13 to 60 months after initial advice. The decrease in diastolic blood pressure was smaller $(0.6 \mathrm{~mm} \mathrm{hg}, 95 \%$ CI 1.5 to -0.3$)$. The data suggest that a low salt diet may help people on anti-hypertensives to stop their medication without losing blood pressure control. The data from TONE suggest that for every 7 patients assigned a goal of achieving a sodium intake of less than $80 \mathrm{mmol} / \mathrm{day}$, one would remain off antihypertensive medication with a BP less than $150 / 90 \mathrm{~mm}$ hg and with no adverse cardiovascular events. 
Effects of low salt dietary advice on mortality and cardiovascular morbidity

Health promotion interventions involve several stages before any health outcome is seen. First, the advice must result in changed behaviour (cutting down on salt in foods) and secondly that behaviour must result in an improved health outcome (reduced cardiovascular illness, increased life expectancy). A major weakness of this review is that we were not able to assess the overall effect of advice to reduce dietary sodium on mortality or morbidity (as not enough events have been accumulated to see any definitive answer). Instead we have tried to follow the process by assessing several intermediate outcomes including urinary sodium excretion and blood pressure; however there may be effects on other risk factors.

It is not clear what effects a low sodium diet has on cardiovascular events and mortality. It has been suggested that lowering sodium intake may have adverse effects on the vascular endothelium through stimulation of the renin-angiotensin system (Alderman 1997), and adverse effects on serum total and LDL cholesterol levels (Graudal 1998) have been suggested. In cohort studies, lower salt intake in hypertensives has been associated with higher levels of cardiovascular disease (Alderman 1995) and in general populations (Alderman 1998; Tunstall-Pedoe 1997) with greater all-cause mortality. However, among obese people lower salt intake may be associated with reduced risk of cardiovascular events (He 1999; Tuomilehto 2001). These apparently contradictory findings emphasizes the fact that we do not know whether long-term salt restriction is beneficial or harmful.

\section{Effects of low salt dietary advice on sodium excretion}

The review suggests that sodium reduction of about a quarter of usual sodium intake in US and UK populations (MAFF 1999) can be achieved long term. This may be exaggerated. For example, HPT found that $48 \%$ of participants ate differently on the day of their food record, eating less food, and substituting simpler foods. Several people in the low sodium group also reported eating less salt on days salt intake was recorded. Whether food adjustment also occurred when urine samples were collected (and whether these were complete) is not known. Male participants in Thaler's trial (Thaler men 1982) were believed to have relaxed their salt restriction between urine samples (O. Simpson, personal communication, 2001).

Is it realistic to ask people to alter their salt intake long term? Advice to reduce dietary salt is common in primary care if the British Hypertension Society's Guidelines (Ramsay 1999; Ramsay 1999a) are being followed. These guidelines advise that 'reduced use of salt when preparing food and elimination of excessively salty foods from the diet' 'be offered to all hypertensive people and those with a strong family history of hypertension'. It does appear that the degree of salt restriction attained attenuates over time (Table 3) and this occurs despite a great deal of ongoing encouragement and support (comprehensive interactive programmes of dietary and behavioural education involving specialized and highly trained staff, vast input of skills, time and materials) in all of the four large high quality trials. The resulting falls of $1.1 \mathrm{~mm}$ hg systolic and 0.6 $\mathrm{mm}$ hg in diastolic blood pressure may be useful at a population level; however the intensity of intervention applied to individuals required to achieve this is not realistic for community control of high blood pressure, which would need to be through changes in food production and catering practices.

\section{Effects of low salt dietary advice on blood pressure}

While both urinary sodium excretion and blood pressure fell, the salt reduction may not have caused the fall in blood pressure. Alterations in diet aimed at reducing salt intake may perhaps systematically affect other dietary components (such as alcohol, potassium, calcium, fat or energy intake) that may themselves alter blood pressure (Cappuccio 1991; Allender 1996; Whelton 1997; Ebrahim 1998; Brand 1999; Griffith 1999). The only available data suggest that potassium is not consistently affected by a low sodium diet, and that weight may be reduced in the medium term, but is unlikely to be exerting much effect on blood pressure by three years. Very little information is available on alcohol (suggesting no major effect), calcium (TOHP phase I reported no significant changes in intake of calcium, but HPT reported a reduction in salt from dairy foods) or fat (suggesting that significant reductions may be occurring in low sodium groups, reported in only one large trial). The significant reduction in weight of people given low sodium dietary advice in the medium, but not the longer term, may explain why the effect of a low sodium diet on blood pressure 'drops off' so much between intermediate and late follow up in this review. It may also explain why, in this review, no relationship is seen between the degree of reduction in sodium excretion and change in blood pressure. However the number of trials is small and relating a mean change in blood pressure to a mean change in urinary sodium is statistically weak. In previous meta-analyses (Table 5) a relationship has been seen in some cases but not in others. Individual participant data are required to take this issue further.

We expected that short duration trials would achieve larger falls in blood pressure that would attenuate over time, in line with attenuation of salt restriction. Trials in normotensives in in the Graudal review (Graudal 1998) (Table 5) had a median length of 8 days, a reduction of $160 \mathrm{mmol} / 24$ hours in urinary sodium excretion and a fall of $1.2 \mathrm{~mm}$ hg in systolic blood pressure, while in this review (median trial length 36 months, $34 \mathrm{mmol} / 24$ hours difference in sodium excretion) systolic blood pressure fell by $1.1 \mathrm{~mm}$ hg. In hypertensives our results are less easy to interpret due to the low quality of included studies, but there is no clear suggestion that blood pressure effects diminish with longer duration trials or with smaller reductions in sodium excretion. This suggests that home- 
ostatic mechanisms (Navar 1997) do not operate over the longer term to re-set usual blood pressure levels as might be expected. It has been suggested that 'usual' blood pressure may be set in utero or early childhood (Barker 1998) so it is possible that dietary salt intake in early childhood has a greater role in determining adult blood pressure than salt intake in adulthood; however the evidence is mixed (Lucas 1988; Hofman 1983; Singhal 2001), and open to varying interpretations (He 2001). A systematic review in this area would be helpful.

Part of the blood pressure lowering effect at longer follow up may be due to lower sodium diets preventing blood pressure rise with age. The Intersalt observational study (Elliott 1996) suggested that a population excreting $100 \mathrm{mmol} /$ day less sodium would experience a 10 and $6 \mathrm{~mm}$ hg lower rise in systolic and diastolic blood pressure over 30 years. This review suggests that voluntary reduction of only $35 \mathrm{mmol} \mathrm{Na} / 24$ hours is realistic for periods of over one year. This would prevent $3-4 \mathrm{~mm}$ hg systolic $(2 \mathrm{~mm}$ hg diastolic) blood pressure rise over thirty years. However, the sodium reduction achieved may decline over time so this additional protective effect of low salt advice may be limited.

The sodium reduction arms of the DASH (Sacks 2001) study are not included in this review as their intervention periods were only 30 days; however the strength of the study was in providing all food for participants and so tightly regulating sodium (as well as potassium and calorie) intake. Participants in the 'control intermediate sodium' arm reduced their sodium excretion by $35 \mathrm{mmol} /$ day compared with the 'control normal sodium' arm, reducing systolic $(2.1 \mathrm{~mm} \mathrm{hg}, 95 \%$ CI 3.4 to $0.8 \mathrm{~mm} \mathrm{hg})$ and diastolic (1.1 $\mathrm{mm} \mathrm{hg,} 95 \%$ CI 1.9 to $0.2 \mathrm{~mm} \mathrm{hg}$ ) blood pressure by amounts similar to those seen in 13-60 month follow up in this review. With greater reductions in sodium, systolic blood pressure decreased by a greater amount ( $6.7 \mathrm{~mm}$ hg. $95 \%$ CI 5.4 to 8.0 ).

\section{Effects of low salt dietary advice on other outcomes}

There is evidence that a low sodium diet improves the chance of maintaining controlled blood pressure following withdrawal of antihypertensives.

There are several reasons for assessing levels of other nutrients in a low sodium diet. Altering any one component of a complex diet will in turn alter the intake of many other micro and macro-nutrients. It is important to ensure that a low sodium diet is nutritionally adequate. It is also necessary to be aware that changes in many nutrients have their own long term effects on blood pressure and other aspects of cardiovascular health. The available data are scant but suggest increases in potassium and magnesium intake, and reductions in energy and total fat intakes, all of which might be expected to help reduce blood pressure in their own right as well as protecting against cardiovascular disease in other ways. This is good news for health, but raises further questions about the extent of the effect of salt reduction itself on blood pressure. It may be that the small changes in blood pressure seen in these long term trials are due to increases in potassium and decreases in fat intake. On the other hand, the reductions in calcium and iron seen in some trials might endanger dietary adequacy for a few people, increasing the risk of osteoporosis and anaemia. It may be that the effect on blood pressure, and more generally on health, of a low sodium diet depends on the types of messages used, the specific dietary measures taken. These may differ considerably from trial to trial, or even from participant to participant.

We have included only a small number of the many randomised controlled trials on the effect of salt manipulation, and none of the intra- or inter-population surveys, cohorts or animal trials that are commonly referred to when the effect of salt reduction on health is discussed. Most of the randomised controlled trials that have been performed have been of short duration and do not assess whether dietary advice has any long term effect on health outcomes or blood pressure. Despite an extensive search, only eleven trials fulfilled our inclusion criteria (determined by our question). Where randomised controlled trials in humans are available to answer a question on health, it would be inappropriate to include animal studies, surveys or cohort studies, which have contradictory results and interpretations (Taubes 1998).

\section{AUTHORS' CONCLUSIONS}

\section{Implications for practice}

Two trials suggest that a low sodium diet helps in preventing elevated blood pressure following withdrawal of antihypertensives. If this is confirmed, with no increase in cardiovascular events, then targeting of comprehensive dietary and behavioural programmes at this group would be justified.

Long term maintenance of low sodium intake for individuals is difficult even with a great deal of support, advice and encouragement. A policy of reduction in salt intake for the entire population, through cutting salt levels in processed foods (MacGregor 1996), as recently announced by the UK's Chief Medical Officer (DoH 2001), is potentially a way of achieving small reductions in blood pressure across the whole population for sustained periods of time. Individual reduction of risk would be small, but across a whole population the effects may be substantial (Stamler 1991; Selmer 2000).

However, raised blood pressure is only one risk factor for cardiovascular disease and overall clinical benefits (or harms) of a reduced sodium diet are unclear - further research is urgently needed to explore this. Deaths and cardiovascular events in the long-term RCTs published to date were too infrequent to answer whether the benefits of sodium restriction outweigh the harms.

\section{Implications for research}

Follow up of all participants of the large trials some years later to 
assess long term effects of low sodium dietary advice on mortality and cardiovascular morbidity would be a cost effective and timely way to assess the clinical effect of low sodium advice. There remains a strong justification for a large, long term RCT to explore the effect of reduced sodium advice on these outcomes in people with borderline and mild elevations of blood pressure.

\section{ACKNOWLEDGEMENTS}

Thanks to: all the trialists and experts who kindly provided unpublished information, including Professor Bruce Arroll (University of Auckland), Professor Olaf Simpson (Dunedin), Dr. Susan Tonascia (Johns Hopkins University), Professor Trefor Morgan (University of Melbourne), Professor Silman (University of Manchester); Dr John Hooper (for Danish translation); Lee's Ph.D. supervisors, Professor Paul Durrington and Dr Helen Worthington (both University of Manchester); Theresa Moore, Katherine Wornell and Margaret Burke of the Cochrane Heart Group; and Ciprian Jauca and Professor Jim Wright of the Cochrane Hypertension Group.

\section{REF ER E N C E S}

\section{References to studies included in this review}

Alli 1992 \{published data only\}

* Alli C, Avanzini F, Bettelli G, Bonati M, Colombo F, Corso R, Di Tullio M, Gentile MG, Sangalli L, Taioli E, Tognoni G. Feasibility of a long-term low-sodium diet in mild hypertension. Journal of Human Hypertension 1992;6 (4):281-286. [MEDLINE: 93059176]

Arroll 1995 \{published and unpublished data\}

* Arroll B, Beaglehole R. Salt restriction and physical activity in treated hypertensives. NZ Med J 1995;108 (1003):266-268. [MEDLINE: 95365076]

Costa 1981 \{published data only\}

* Costa FV, Ambrosioni E, Montebugnoli L, Paccaloni L, Vasconi L, Magnani B. Effects of low-salt diet and of acute salt loading on blood pressure and intralymphatic sodium concentration in young subjects with borderline hypertension. Clinical Science 1981;61 (Supplement 7): 21s-23s. [MEDLINE: 82094132]

HPT \{published and unpublished data\}

Borhani NO, Tonascia J, Schlundt DG, Prineas RJ, Jefferys JL. Recruitment in the Hypertension Prevention trial. Hypertension Prevention Trial Research Group. Controlled Clin Trials 1989;10(3 Suppl):30S-39S. [MEDLINE: 90031597]

Brown KM, Oberman A, Van Natta ML, Forster JL. Baseline characteristics in the hypertension prevention trial. Controlled Clinical Trials 1989;10(3 supplement):40S-64S. [MEDLINE: 90031598]

Forster JL, Jeffery RW, VanNatta M, Pirie P. Hypertension prevention trial: do $24-\mathrm{h}$ food records capture usual eating behavior in a dietary study?. Am J Clin Nutr 1990;51(2): 253-257. [MEDLINE: 90164468]

* Hypertension Prevention Trial Research Group. The Hypertension Prevention Trial: three-year effects of dietary changes on blood pressure. Arch Intern Med 1990;150(1): 153-162. [MEDLINE: 90120838] Jeffery RW, French SA, Schmid TL. Attributions for dietary failures: problems reported by participants in the
Hypertension Prevention Trial. Health Psychol 1990;9(3): 315-329. [MEDLINE: 90255462]

Jeffery RW, Tonascia S, Bjornson BW, Schlundt DG, Sugars C for the Hypertension Prevention Trial Research Group.

Treatment in the Hypertension Prevention Trial. Controlled Clin Trials 1989;10(3 Suppl):65S-83S. [MEDLINE: 90031599]

Meinert CL, Borhani NO, Langford HG. Design, methods, and rationale in the Hypertension Prevention Trial.

Hypertension Prevention Trial Research Group. Controlled Clin Trials 1989;10(3 Suppl):1S-29S. [MEDLINE: 90031596]

Prud'homme GJ, Canner PL, Cutler JA. Quality assurance and monitoring in the Hypertension Prevention Trial. Hypertension Prevention Trial Research Group. Controlled Clin Trials 1989;10(3 Suppl):84S-94S. [MEDLINE: 90031600]

Schmid TL, Jeffery RW, Onstad L, Corrigan SA.

Demographic, knowledge, physiological, and behavioral variables as predictors of compliance with dietary treatment goals in hypertension. Addictive Behaviors 1991;16(3-4): 151-160. [MEDLINE: 91289809]

Shah M, Jeffery RW, Laing B, Savre SG, Van NM, Strickland D. Hypertension Prevention Trial (HPT): food pattern changes resulting from intervention on sodium, potassium, and energy intake. Hypertension Prevention Trial Research Group. J Am Diet Assoc 1990;90(1):69-76. [MEDLINE: 90110778]

Morgan 1978 \{published and unpublished data\}

* Morgan T, Adam W, Gillies A, Wilson M, Morgan G, Carney S. Hypertension treated by salt restriction. Lancet 1978;1(8058):227-230. [MEDLINE: 78091122] Morgan TO, Adams WR, Hodgson M, Gibberd RW. Failure of therapy to improve prognosis in elderly males with hypertension. Medical Journal of Australia 1980;2(1): 27-31. [MEDLINE: 81051857]

Morgan 1987 \{published data only\}

* Morgan T, Anderson A. Sodium restriction can delay the return of hypertension in patients previously well-controlled on drug therapy. Can J Physiol Pharmacol 1987;65(8): 
1752-1755. [MEDLINE: 88079620]

Silman 1983 \{published data only\}

Silman AJ, Locke C, Humpherson P. Salt restriction and no drug treatment in mild to moderate hypertension [letter]. Lancet 1982;1(8277):903-904. [MEDLINE: 82172148]

* Silman AJ, Locke C, Mitchell P, Humpherson P. Evaluation of the effectiveness of a low sodium diet in the treatment of mild to moderate hypertension. Lancet 1983;1 (8335):1179-1182. [MEDLINE: 83217784]

Thaler men 1982 \{published and unpublished data\}

* Thaler BI, Paulin JM, Phelan EL, Simpson FO. A pilot study to test the feasibility of salt restriction in a community. $N Z$ Med J 1982;95(721):839-842. [MEDLINE: 83142430]

Thaler women 1982 \{published and unpublished data\}

* Thaler BI, Paulin JM, Phelan EL, Simpson FO. A pilot study to test the feasibility of salt restriction in a community. $N Z$ Med J 1982;95(721):839-842. [MEDLINE: 83142430]

TOHP phase I \{published data only\}

Cook NR, Kumanyika SK, Cutler JA. Effect of change in sodium excretion on change in blood pressure corrected for measurement error. Am J Epidemiol 1998;148(5):431-444. [MEDLINE: 98407573]

He J, Whelton PK, Appel LJ, Charleston J, Klag MJ. Longterm effects of weight loss and dietary sodium reduction on incidence of hypertension.. Hypertension 2000;35(2): 544-550. [MEDLINE: 20145848]

Kumanyika SK, Hebert PR, Cutler JA, Lasser VI, Sugars CP, Steffen BL, Brewer AA, Cameron M, Shepek LD, Cook NR, et a. Feasibility and efficacy of sodium reduction in the Trials of Hypertension Prevention, phase I. Trials of Hypertension Prevention Collaborative Research Group. Hypertension 1993;22(4):502-512. [MEDLINE: 94011135]

Sacks FM, Hebert P, Appel LJ, Borhani NO, Applegate WB, Cohen JD, Cutler JA, Kirchner KA, Kuller LH, Roth $\mathrm{KJ}$, et a. The effect of fish oil on blood pressure and highdensity lipoprotein-cholesterol levels in phase I of the Trials of Hypertension Prevention. Trials of Hypertension Prevention Collaborative Research Group. J Hypertens Suppl 1994;12(7):S23-S31. [MEDLINE: 95287279]

Satterfield S, Cutler JA, Langford HG, Applegate WB, Borhani NO, Brittain E, Cohen JD, Kuller LH, Lasser NL, Oberman A, Rosner B, Taylor JO, Vogt TM, Walker G, and Whelton PK for the Trials of Hypertension Prevention Collaborative Research Group. Trials of hypertension prevention. Phase I design. Ann Epidemiol 1991;1(5): 455-471. [MEDLINE: 94093770]

Stevens VJ, Corrigan SA, Obarzanek E, Bernauer E, Cook NR, Hebert P, Mattfeldt BM, Oberman A, Sugars C, Dalcin AT, Whelton PK for the TOHP Collaborative Research Group. Weight loss intervention in phase 1 of the Trials of Hypertension Prevention. Arch Intern Med 1993;153(7): 849-858. [MEDLINE: 93221340]

* The Trials of Hypertension Prevention Collaborative Research Group. The effects of nonpharmacologic interventions on blood pressure of persons with high normal levels: results of the Trials of Hypertension Prevention, Phase I. JAMA 1992;267(9):1213-1220. [MEDLINE: 92167528]

Whelton PK, Buring J, Borhani NO, Cohen JD, Cook N, Cutler JA, Kiley JE, Kuller LH, Satterfield S, Sacks FM and Taylor JO for the Trials Of Hypertension Prevention (TOPH) Collaborative Research Group. The effect of potassium supplementation in persons with a high-normal blood pressure. Results from phase I of the Trials of Hypertension Prevention (TOHP). Trials of Hypertension Prevention (TOPH) Collaborative Research Group. Ann Epidemiol 1995;5(2):85-95. [MEDLINE: 95316194] Whelton PK, Hebert PR, Cutler J, Applegate WB, Eberlein KA, Klag MJ, Keough ME, Hamill S, Borhani NO, Hollis $\mathrm{J}$ and Oberman A for the Trials of Hypertension Prevention Collaborative Research Group et a. Baseline characteristics of participants in phase I of the Trials of Hypertension Prevention. Ann Epidemiol 1992;2(3): 295-310. [MEDLINE: 94101134]

Whelton PK, Kumanyika SK, Cook NR, Cutler JA, Borhani NO, Hennekens CH, Kuller LH, Langford H, Jones DW, Satterfield S, Lasser NL, Cohen JD. Efficacy of nonpharmacologic interventions in adults with highnormal blood pressure: results from phase 1 of the Trials of Hypertension Prevention. Trials of Hypertension Prevention Collaborative Research Group. Am J Clin Nutr 1997;65(2 Suppl):652S-660S. [MEDLINE: 97174901] Yamamoto ME, Applegate WB, Klag MJ, Borhani NO, Cohen JD, Kirchner KA, Lakatos E, Sacks FM, Taylor JO, Hennekens $\mathrm{CH}$. Lack of blood pressure effect with calcium and magnesium supplementation in adults with highnormal blood pressure. Results from Phase I of the Trials of Hypertension Prevention (TOHP). Trials of Hypertension Prevention (TOHP) Collaborative Research Group. Ann Epidemiol 1995;5(2):96-107. [MEDLINE: 95316195]

\section{TOHP phase II \{published data only\}}

Appel LJ, Hebert PR, Cohen JD, Obarzanek E, Yamamoto M, Buring J, Stevens V, Kirchner K, Borhani NO. Baseline characteristics of participants in phase II of the Trials of Hypertension Prevention (TOHP II). Trials of Hypertension Prevention (TOHP) Collaborative Research Group. Ann Epidemiol 1995;5(2):149-155. [MEDLINE: 95316191]

Hebert PR, Bolt RJ, Borhani NO, Cook NR, Cohen JD, Cutler JA, Hollis JF, Kuller LH, Lasser NL, Oberman A, Miller ST, Morris C, Whelton PK, Hennekens CH, for the Trials of Hypertension Prevention (TOHP) Collaborative Research Group. Design of a multicenter trial to evaluate long-term life-style intervention in adults with highnormal blood pressure levels. Trials of Hypertension Prevention (Phase II).. Ann Epidemiol 1995;5(2):130-139. [MEDLINE: 95316189]

Hollis JF, Satterfield S, Smith F, Fouad M, Allender PS, Borhani N, Charleston J, Hirlinger M, King N, Schultz R, Sousoulas BG, on behalf of Trials of Hypertension Prevention (TOHP) Collaborative Research Group. 
Recruitment for phase II of the Trials of Hypertension Prevention. Effective strategies and predictors of randomization.. Ann Epidemiol 1995;5(2):140-148. [MEDLINE: 95316190]

Hunt SC, Cook NR, Oberman A, Cutler JA, Hennekens $\mathrm{CH}$, Allender PS, Walker WG, Whelton PK, Williams RR. Angiotensinogen genotype, sodium reduction, weight loss, and prevention of hypertension. Trials of Hypertension Prevention, Phase II. Hypertension 1998;32(3):393-401. [MEDLINE: 98413188]

Lasser VI, Raczynski JM, Stevens VJ, Mattfeldt-Beman M, Kumanyika S, Evans M, Danielson E, Dalcin A, Batey DM, Belden LK and Brewer AA for the Trials Of Hypertension Prevention (TOPH) Collaborative Research Group. Trials of Hypertension Prevention, phase II. Structure and content of the weight loss and dietary sodium reduction interventions. Trials of Hypertension Prevention (TOHP) Collaborative Research Group. Ann Epidemiol 1995;5(2): 156-164. [MEDLINE: 95316192]

* The Trials of Hypertension Prevention Collaborative Research Group. Effects of weight loss and sodium reduction intervention on blood pressure and hypertension incidence in overweight people with high-normal blood pressure. The Trials of Hypertension Prevention, phase II. Arch Intern Med 1997;157(6):657-667. [MEDLINE: 97236001]

\section{TONE \{published data only\}}

Appel LJ, Espeland M, Whelton PK, Dolecek T, Kumanyika S, Applegate WB, Ettinger WH Jr, Kostis JB, Wilson AC, Lacy C, Miller ST. Trial of Nonpharmacologic Intervention in the Elderly (TONE). Design and rationale of a blood pressure control trial. Ann Epidemiol 1995;5(2):119-129. [MEDLINE: 95316188]

Appel LJ, Espeland MA, Easter L, Wilson AC, Folmar S, Lacy CR. Effects of redcued sodium intake on hypertension control in older individuals. Results from the Trial of Nonpharmacological Interventions in the Elderly (TONE). Arch Intern Med 2001;161(5):685-693. [MEDLINE: 21152543]

Bahnson JL, Whelton PK, Appel LJ, Espeland MA, Wofford JL, Rosen R, Wilson AC, Lacey CR, Rutan G, Hogan P, Tayback M, Dolecek TA, Shindler D. Baseline characteristics of randomized participants in the trial of nonpharmacologic intervention in the elderly (TONE). Disease Management and Clinical Outcomes 1997;1(2): 61-68. [: EMBASE Accession number is 1998019109] Espeland MA, Whelton PK, Kostis JB, Bahnson JL, Ettinger WH, Cutler JA, Appel LJ, Kumanyika S, Farmer D, Elam J, Wilson AC, Applegate WB. Predictors and mediators of successful long-term withdrawal from antihypertensive medications. Arch Fam Med 1999;8(3): 228-236. [MEDLINE: 99266360]

Kostis JB, Espeland MA, Appel LJ, Johnson KC, Pierce J, James L. Does withdrawal of antihypertensive medication increase the risk of cardiovascular events?. Am J Cardiol 1998;82(12):1501-1508. [MEDLINE: 99089451]

* Whelton PK, Appel LJ, Espeland MA, Applegate WB,
Ettinger WH Jr, Kostis JB, Kumanyika S, Lacy CR, Johnson KC, Folmar S, Cutler JA for the TONE Collaborative Research Group. Sodium reduction and weight loss in the treatment of hypertension in older persons: a randomized controlled trial of nonpharmacologic interventions in the elderly (TONE). JAMA 1998;279(11):839-846. [MEDLINE: 98175759]

Whelton PK, Bahnson J, Appel LJ, Charleston J, Cosgrove N, Espeland MA, Folmar S, Hoagland D, Krieger S, Lacy C, Lichtermann L, Oates WF, Tayback M, Wilson AC. Recruitment in the Trial of Nonpharmacologic Intervention in the Elderly (TONE). J Am Geriatr Soc 1997;45(2): 185-193. [MEDLINE: 97185836]

\section{References to studies excluded from this review}

\section{Aberg 1989 \{published data only\}}

* Aberg H, Tibblin G. Addition of non-pharmacological methods of treatment in patients on antihypertensive drugs: results of previous medication, laboratory tests and life quality. Journal of Internal Medicine 1989;226(1):39-46. [MEDLINE: 89328303]

Ambard 1904 \{published data only\}

Ambard L. Causes de l'hypertension arterielle. Archives of General Medicine 1904;1:520-533.

Ambrosioni 1982 \{published data only\}

Ambrosioni E, Costa F, Borghi C, montebugnoli M, Giordani M, Vasconi L. Effects of moderate salt restriction and high potassium intake on intralymphocytic sodium content and pressor response to stress in borderline hypertension. Clinical Science 1982;63:231S-234S.

Anderson 1990 \{published data only\}

* Anderson A, Morgan T. Interaction of enalapril with sodium restriction, diuretics, and slow-channel calciumblocking drugs. Nephron 1990;55(Suppl 1):70-72. [MEDLINE: 90265449]

Berglund 1989 \{published data only\} Berglund A, Andersson OK, Berglund G, Fagerberg B. Antihypertensive effect of diet compared with drug treatment in obese men with mild hypertension. BMJ 1989; 299(6697):480-485. [MEDLINE: 90001793]

\section{Bompiani 1988 \{published data only\}}

Bompiani GD, Cerasola G, Morici M, Condorelli M, Trimarco B, de Luca N, Leonetti G, Sampieri L, Cuspidi C, Cottone S, D'Ignoto G. Effects of moderate low sodium / high potassium diet on essential hypertension: results of a comparative study. Int Journal of Clinical Phrmacology, Therapy and Toxicology 1988;26(3):129-132. [MEDLINE: 88314399]

\section{Cappuccio 1997 \{published data only\}}

* Cappuccio FP, Markandu ND, Carney C, Sagnella GA, MacGregor GA. Double-blind randomised trial of modest salt restriction in older people [see comments]. Lancet 1997; 350(9081):850-854. [MEDLINE: 97456646]

\section{Carney 1975 \{published data only\}}

Carney S, Morgan T, Wilson M, Matthews G, Roberts R. Sodium restriction and thiazide diuretics in the treatment 
of hypertension. Medical Journal of Australia 1975;1(26): 803-807. [MEDLINE: 75215971]

Corcoran 1951 \{published data only\}

* Corcoran AC, Taylor RD, Page IH. Controlled observations on the effect of low sodium dietotherapy in essential hypertension. Circulation 1951;III:1-16.

Dahl 1958 \{published data only\}

Dahl L, Silver L, Christie R. The role of salt in teh fall of blood pressure accompanying reduction in obesity. New England Journal of Medicine 1958;258:1186-1192. [MEDLINE: 58095969]

\section{DASH \{published data only\}}

Appel LJ, Moore TJ, Obarzanek E, Vollmer WM, Svetkey LP, Sacks FM, Bray GA, Vogt TM, Cutler JA, Windhauser MM, Lin PH, Karanja N. A clinical trial of the effects of dietary patterns on blood pressure. DASH Collaborative Research Group. N Engl J Med 1997;336(16):1117-1124. [MEDLINE: 97238752]

Sacks FM, Appel LJ, Moore TJ, Obarzanek E, Vollmer WM, Svetkey LP, Bray GA, Vogt TM, Cutler JA, Windhauser MM, Lin PH, Karanja N. A dietary approach to prevent hypertension: a review of the dietary approaches to stop hypertension (DASH) study. Clinical Cardiology 1999;22(7 Supplement):III 6-10. [MEDLINE: 99338488] Sacks FM, Svetkey LP, Vollmer WM, Appel LJ, Bray GA, Harsha D, Obarzanek E, Conlin PR, Miller ERI, SimonsMorton DG, Karanja N, Lin P-H, Aickin M, MostWindhauser MM, Moore TJ, Proschan MA, Cutler JA. Effects on blood pressure of reduced dietary sodium and the Dietary Approaches to Stop Hypertension (DASH) diet. New England Journal of Medicine 2001;344(1):3-10. [MEDLINE: 21012263]

Svetkey LP, Simons-Morton DG, Vollmer WM, Appel LJ, Conlin PR, Ryan DH, Ard J, Kennedy BM. Effects of dietary patterns on blood pressure: subgroup analysis of the dietary approaches to stop hypertension (DASH) randomized clinical trial. Archives of Internal Medicine 1999;159(3):285-293. [MEDLINE: 99142647]

DISH \{published data only\}

* Blaufox MD, Langford HG, Oberman A, Hawkins CM, Wassertheil SS, Cutter GR. Effect of dietary change on the return of hypertension after withdrawal of prolonged antihypertensive therapy (DISH). Dietary Intervention Study of Hypertension. J Hypertens Suppl 1984;2(3): S179-S181. [MEDLINE: 86199066]

Langford HG, Blaufox MD, Oberman A, Hawkins CM, Curb JD, Cutter GR, Wassertheil SS, Pressel S, Babcock C, Abernethy JD, et a. Dietary therapy slows the return of hypertension after stopping prolonged medication. JAMA 1985;253(5):657-664. [MEDLINE: 85108285]

Wassertheil SS, Blaufox MD, Langford HG, Oberman A, Cutter G, Pressel S. Prediction of response to sodium intervention for blood pressure control. J Hypertens Suppl 1986;4(5):S343-S346. [MEDLINE: 87197751] Wassertheil SS, Langford HG, Blaufox MD, Oberman A, Hawkins M, Levine B, Cameron M, Babcock C, Pressel $\mathrm{S}$, Caggiula A, et a. Effective dietary intervention in hypertensives: sodium restriction and weight reduction. J Am Diet Assoc 1985;85(4):423-430. [MEDLINE: 85158652]

\section{Dole 1951 \{published data only\}}

Dole V, Dahl L, Cotzias G, Dziewiatkowski D, Harris C. Dietary treatment of hypertension. II Sodium depletion as related to the therapeutic effect. Journal of Clinical Investigation 1951;30:584-595.

Dubbert 1995 \{published data only\} Dubbert PM, Cushman WC, Meydrech EF, Rowland AK, Maury P. Effects of dietary instruction and sodium excretion feedback in hypertension clinic patients. Behavior Therapy 1995;26(4):721-732. [MEDLINE: 1995342245]

Erwteman 1984 \{published data only\}

* Erwteman TM, Nagelkerke N, Lubsen J, Koster M, Dunning AJ. Beta blockade, diuretics, and salt restriction for the management of mild hypertension: a randomised double blind trial. Br Med J Clin Res Ed 1984;289(6442): 406-409. [MEDLINE: 84281599]

Evers 1987 \{published data only\}

Evers SE, Bass M, Donner A, McWhinney IR. Lack of impact of salt restriction advice on hypertensive patients. Preventive Medicine 1987;16(2):213-220. [MEDLINE: 87231784]

Fagerberg 1984 \{published data only\} * Fagerberg B, Andersson OK, Isaksson B, Bjorntorp P. Blood pressure control during weight reduction in obese hypertensive men: separate effects of sodium and energy restriction. Br Med J Clin Res Ed 1984;288(6410):11-14. [MEDLINE: 84081362]

Geleijnse 1995 \{published data only\}

* Geleijnse JM, Witteman JC, Bak AA, den BJ, Grobbee DE. Long-term moderate sodium restriction does not adversely affect the serum $\mathrm{HDL} /$ total cholesterol ratio. J Hum Hypertens 1995;9(12):975-979. [MEDLINE: 96362947]

Gillum 1983 \{published data only\}

* Gillum RF, Prineas RJ, Jeffery RW, Jacobs DR, Elmer PJ, Gomez O, Blackburn H. Nonpharmacologic therapy of hypertension: the independent effects of weight reduction and sodium restriction in overweight borderline hypertensive patients. Am Heart J 1983;105(1):128-133. [MEDLINE: 83097284]

Grimm 1990 \{published data only\}

* Grimm RH Jr, Neaton JD, Elmer PJ, Svendsen KH, Levin J, Segal M, Holland L, Witte LJ, Clearman DR, Kofron P, La Bounty RK, Crow R, Prineas RJ. The influence of oral potassium chloride on blood pressure in hypertensive men on a low-sodium diet. $N$ Engl J Med 1990;322(9):569-574. [MEDLINE: 90158725]

HCP \{published data only\} Stamler R, Grimm RH Jr, Dyer AR, Talano JV, Prineas R, Crow R, Berman R, Gosch FC, Elmer P, Stamler J. Cardiac status after four years in a trial on nutritional therapy 
for high blood pressure. Arch Intern Med 1989;149(3): 661-665. [MEDLINE: 89149275]

Stamler R, Stamler J, Grimm R, Dyer A, Gosch FC, Berman R, Elmer P, Fishman J, Van Heel N, Civinelli J, Hoeksema R. Nonpharmacological control of hypertension. Prev Med 1985;14(3):336-345. [MEDLINE: 86042572]

Stamler R, Stamler J, Grimm R, Gosch F, Dyer A, Berman R, Civinelli J, Elmer P, Fishman J, Van Heel N, McDonald A, McKeever P. Trial on control of hypertension by nutritional means: three-year results. J Hypertens Suppl 1984;2(3):S167-S170. [MEDLINE: 87141518] Stamler R, Stamler J, Grimm R, Gosch FC, Elmer P, Dyer A, Berman R, Fishman J, Van Heel N, Civinelli J, McDonald A. Nutritional therapy for high blood pressure. Final report of a four-year randomized controlled trial-the Hypertension Control Program. JAMA 1987;257(11): 1484-1491. [MEDLINE: 87141518]

Stamler R, Stamler J, Grimm R, Gosch FC, Elmer P, Dyer A, Berman R, Fishman J, Van Heel N, Civinelli J, McDonald A. Nutritional therapy for high blood pressure. Final report of a four-year randomized controlled trial-the Hypertension Control Program. JAMA 1987;257(11): 1484-1491. [MEDLINE: 86199063]

Henningsen 1980 \{published data only\}

* Henningsen NC. Salt and essential hypertension. [Swedish]. Var Foda 1980;32(6/7):345-354.

Holly 1981 \{published data only\}

* Holly JM, Goodwin FJ, Evans SJ, Vandenburg MJ, Ledingham JM. Re-analysis of data in two Lancet papers on the effect of dietary sodium and potassium on blood pressure. Lancet 1981;2(8260-61):1384-1387. [MEDLINE: 82079762]

Iwaoka 1994 \{published data only\}

* Iwaoka T, Umeda T, Inoue J, Naomi S, Sasaki M, Fujimoto Y, Gui C, Ideguchi Y, Sato T. Dietary $\mathrm{NaCl}$ restriction deteriorates oral glucose tolerance in hypertensive patients with impairment of glucose tolerance. $\mathrm{Am} \mathrm{J}$ Hypertens 1994;7(5):460-463. [MEDLINE: 94338640]

\section{Jula 1990 \{published data only\}}

* Jula A, Ronnemaa T, Rastas M, Karvetti RL, Maki J. Long-term nopharmacological treatment for mild to moderate hypertension. J Intern Med 1990;227(6): 413-421. [MEDLINE: 90278339]

Jula 1992a \{published data only\}

* Jula A, Ronnemaa T, Tikkanen I, Karanko H. Responses of atrial natriuretic factor to long-term sodium restriction in mild to moderate hypertension. J Intern Med 1992;231(5): 521-529. [MEDLINE: 92291706]

\section{Jula 1992b \{published data only\}}

* Jula AM, Ronnemaa TE, Piha SJ, Maki JP. Response of diastolic blood pressure to long-term sodium restriction is posture related. Scandinavian Journal of Clinical and Laboratory Investigation 1992;52(3):159-167. [MEDLINE: 9303401]
Jula 1994 \{published data only\}

* Jula AM, Karanko HM. Effects on left ventricular hypertrophy of long-term nonpharmacological treatment with sodium restriction in mild-to-moderate essential hypertension. Circulation 1994;89(3):1023-1031. [MEDLINE: 94170458]

\section{Koopman 1990 \{published data only\}}

* Koopman H, Spreeuwenberg C, Westerman RF, Donker AJ. Dietary treatment of patients with mild to moderate hypertension in a general practice: a pilot intervention study (2). Beyond three months. J Hum Hypertens 1990;4 (4):372-374. [MEDLINE: 91080076]

Koopman H, Spreeuwenberg C, Westerman RF, Donker AJM. Dietary treatment of patients with mild to moderate hypertension in a general practice: a pilot intervention study. (2) Beyond 3 months. Journal of Human Hypertension 1990;4(4):372-374. [MEDLINE: 91080076]

Korhonen 1999 \{published data only\}

Korhonen MH, Litmanen H, Rauramaa R, Vaisanen SB, Niskanen L, Uusitupa J. Adherence to the salt restriction diet among people with mildly elevated blood pressure. European Jouranl of Clinical Nutrition 1999;53(11): 880-885. [MEDLINE: 20025972]

Logan 1986 \{published and unpublished data\} Logan AG. Sodium manipulation in the management of hypertension. The view against its general use. Canadian Journal of Physiology and Pharmacology 1986;64(6):

793-802. [MEDLINE: 87001697]

* Logan AG, Flanagan PT, Haynes RB. Effect of dietary sodium restriction alone in the treatment of mild hypertension. unpublished.

MacGregor 1982a \{published data only\} MacGregor GA, Markandu ND, Sagnella GA. Dietary sodium restriction in normotensive subjects and patients with essential hypertension. Clin Sci 1982;63:399S-402S.

MacGregor 1982b \{published data only\} MacGregor GA, Markandu ND, Best FE, Elder DM, Cam JM, Sagnella GA, Squires M. Double-blind randomised crossover trial of moderate sodium restriction in essential hypertension. Lancet 1982;1(8268):351-355. [MEDLINE: 82123995]

MacGregor 1989 \{published data only\} * MacGregor GA, Markandu ND, Sagnella GA, Singer DR, Cappuccio FP. Double-blind study of three sodium intakes and long-term effects of sodium restriction in essential hypertension. Lancet 1989;2(8674):1244-1247. [MEDLINE: 90065792]

\section{Magnani 1976 \{published data only\}}

Magnani B, Ambrosioni E, Agosta R, Racco F. Comparison of the effects of pharmacological therapy anda low-sodium diet on mild hypertension. Clin Sci Mol Med Suppl 1976;3: 625S-626S. [MEDLINE: 77161090]

McDonald 1988 \{published data only\} * McDonald AM, Dyer AR, Liu K, Stamler R, Gosch FC, Grimm R, Berman R, Stamler J. Sodium, lithiumcountertransport and blood pressure control by nutritional 
intervention in 'mild' hypertension. J Hypertens 1988;6(4): 283-291. [MEDLINE: 88244364]

\section{Morgan 1988 \{published data only\}}

Morgan T, Anderson A. Interaction in hypertensive men between sodium intake, converting enzyme inhibitor (enalapril), plasma renin and blood pressure control. Journal of Human Hypertension 1988;1(4):311-315. [MEDLINE: 89125550]

Muhlhauser 1993 \{published data only\}

* Muhlhauser I, Sawicki PT, Didjurgeit U, Jorgens V, Trampisch HJ, Berger M. Evaluation of a structured treatment and teaching programme on hypertension in general practice. Clin Exp Hypertens 1993;15(1):125-142. [MEDLINE: 93222829]

Myers 1989 \{published data only\} Myers JB. Reduced sodium chloride intake normalises blood pressure distribution. Journal of Human Hypertension 1989;3(2):97-104. [MEDLINE: 89342389]

Nestel 1993 \{published data only\}

* Nestel PJ, Clifton PM, Noakes M, McArthur R, Howe PR. Enhanced blood pressure response to dietary salt in elderly women, especially those with small waist:hip ratio. Journal of Hypertension 1993;11(12):1387-1394. [MEDLINE: 94179778]

Neyses 1985 \{published data only\}

* Neyses L, Dorst K, Michaelis J, Berres M, Philipp T, Distler A, Losse H, Vetter H, Epstein FH, Vetter W. Compliance with salt restriction as a limiting factor in the primary prevention of hypertension. J Hypertens Suppl 1985;3(1):S87-S90. [MEDLINE: 87253502]

Nicholson 1986 \{published data only\}

* Nicholson JP, Resnick LM, Laragh JA. The impact of dietary sodium intake on the hypotensive response of verapamil in essential hypertension. J Clin Hypertens 1986; 2(3 Suppl):143S-147S. [MEDLINE: 87085718]

Nicholson 1987 \{published data only\}

* Nicholson JP, Resnick LM, Laragh JH. The antihypertensive effect of verapamil at extremes of dietary sodium intake. Ann Intern Med 1987;107(3):329-334. [MEDLINE: 87297036]

Nowson 1988 \{published data only\}

* Nowson CA, Morgan TO. Change in blood pressure in relation to change in nutrients effected by manipulation of dietary sodium and potassium. Clinical and Experimental Pharmacology and Physiology 1988;15(3):225-242.

[MEDLINE: 90150703]

Nugent 1984 \{published data only\}

Nugent CA, Carnahan JE, Sheehan ET, Myers C. Salt restriction in hypertensive patients. Comparison of advice, education and group management.. Archives of Internal Medicine 1984;144(7):1415-1417. [MEDLINE: 84230406]

ODES \{published data only\}

Anderssen S, Holme I, Urdal P, Hjermann I. Diet and exercise intervention have favourable effects on blood pressure in mild hypertensives: the Oslo Diet and Exercise Study. (ODES). Blood Pressure 1995;4(6):343-349.

[MEDLINE: 96356286]

Omvik 1986 \{published data only\}

* Omvik P, Lund-Johansen P. Is sodium restriction effective treatment of borderline and mild essential hypertension? A long-term haemodynamic study at rest and during exercise. Journal of Hypertension 1986;4(5):535-541. [MEDLINE: 87084739]

Omvik 1995 \{published data only\}

* Omvik P, Myking OL. Unchanged central hemodynamics after six months of moderate sodium restriction with or without potassium supplement in essential hypertension. Blood Press 1995;4(1):32-41. [MEDLINE: 95253445]

Parijs 1973 \{published data only\}

* Parijs J, Joossens JV, Van der Linden L, Verstreken G, Amery AK. Moderate sodium restriction and diuretics in the treatment of hypertension. American Heart Journal 1973;85(1):22-34. [MEDLINE: 73052205]

Perera 1947 \{published data only\}

Perera G, Blood D. The relationship of sodium choride to hypertension. Journal of Clinical Investigation 1947;26: 1109-1117.

Priddle 1962 \{published data only\} Priddle W. Hypertension-sodium and potassium studies. Journal of the Canadian Medical Association 1962;86(1):1-9. [: Medline Unique Identifier is 62090301]

Rissanen 1985 \{published data only\}

* Rissanen A, Pietinen P, Siljamaki OU, Piirainen H, Reissel P. Treatment of hypertension in obese patients: efficacy and feasibility of weight and salt reduction programs. Acta Med Scand 1985;218(2):149-156. [MEDLINE: 86047190]

Roca-Cusachs 1991 \{published data only\}

* Roca-Cusachs A, Sort D, Altimira J, Bonet R, Guilera E, Monmany J, Nolla J. The impact of a patient education programme in the control of hypertension. J Hum Hypertens 1991;5(5):437-441. [MEDLINE: 92122169]

Sagnella 1987 \{published data only\}

* Sagnella GA, Markandu ND, Buckley MG, Singer DR, Sugden AL, Shore AC, MacGregor GA. Plasma atrial natriuretic peptide in essential hypertension: effects of changes in dietary sodium. Br Med J Clin Res Ed 1987;295 (6595):417-418. [MEDLINE: 88001459]

Shibata 1979 \{published data only\}

Shibata H, Hatano S. A salt restriction trial in Japan. In: Gross F, Strasser T editor(s). Mild hypertension: natural history and management. Bath: Pitman Medical, 1979.

Singer 1984 \{published data only\} Singer DR, Markandu ND, Cappuccio FP, Miller MA, Sagnella GA, Skrabal F, Gasser RW, Finkenstedt G, Rhomberg HP, Lochs A. Low-sodium diet versus lowsodium/high-potassium diet for treatment of hypertension. Klinische. Wochenschrift 1984;62(3):124-128. [MEDLINE: 84165933] 
Singer 1995 \{published data only\}

Singer DR, Markandu ND, Cappuccio FP, Miller MA, Sagnella GA, MacGregor GA. Reduction of salt intake during converting enzyme inhibitor treatment compared with addition of a thiazide. Hypertension 1995;25(5): 1042-1044. [MEDLINE: 95255896]

Stamler 1989 \{published data only\}

Stamler R, Stamler J, Gosch FC, Civinelli J, Fishman J, McKeever P, McDonald A, Dyer AR. Primary prevention of hypertension by nutritional-hygienic means. Final report of a randomized, controlled trial [published erratum appears in JAMA 1989 Dec 8;262(22):3132]. JAMA 1989;262 (13):1801-1807. [MEDLINE: 89382841] Stamler R, Stamler J, Gosch FC, McDonald AM. Primary prevention of hypertension--a randomized controlled trial. Ann Clin Res 1984;16(Supplement 43):136-142. [MEDLINE: 85223780]

TAIM \{published data only\}

Blaufox MD, Lee HB, Davis B, Oberman A, WassertheilSmoller S, Langford H. Renin predicts diastolic blood pressure response to nonpharmacologic and pharmacologic therapy. JAMA 1992;267(9):1221-1225. [MEDLINE: 92167529]

Davis BR, Blaufox MD, Oberman A, Wassertheil-Smoller S, Zimbaldi N, Cutler JA, Kirchner K, Langford HG. Reduction in long-term antihypertensive medication requirements. Effects of weight reduction by dietary intervention in overweight persons with mild hypertension. Arch Intern Med 1993;153(15):1773-1782. [MEDLINE: 93326077]

Davis BR, Oberman A, Blaufox MD, Wassertheil-Smoller S, Hawkins CM, Cutler JA, Zimbaldi N, Langford HG. Effect of antihypertensive therapy on weight loss. The Trial of Antihypertensive Interventions and Management Research Group. Hypertension 1992;19(4):393-399. [MEDLINE: 92210170]

Davis BR, Oberman A, Blaufox MD, Wassertheil-Smoller S, Zimbaldi N, Kirchner K, Wylie-Rosett J, Langford HG. Lack of effectiveness of a low-sodium/high-potassium diet in reducing antihypertensive medication requirements in overweight persons with mild hypertension. TAIM Research Group. Trial of Antihypertensive Interventions and Management. Am J Hypertens 1994;7(10 Pt 1): 926-932. [MEDLINE: 95127141]

Langford HG, Davis BR, Blaufox D, Oberman A, Wassertheil-SmollerS, Hawkins M, Zimbaldi N. Effect of drug and diet treatment of mild hypertension on diastolic blood pressure. The TAIM Research Group. Hypertension 1991;17(2):210-217. [MEDLINE: 91122830]

Oberman A, Wassertheil-Smoller S, Langford HG, Blaufox MD, Davis BR, Blaszkowski T, Zimbaldi N, Hawkins CM. Pharmacologic and nutritional treatment of mild hypertension: changes in cardiovascular risk status [see comments]. Ann Intern Med 1990;112(2):89-95. [MEDLINE: 90103317]

Wassertheil-Smoller S, Davis BR, Breuer B, Chee JC, Oberman A, Blaufox MD. Differences in precision of dietary estimates among different population subgroups. Ann Epidemiol 1993;3(6):619-628. [MEDLINE: 95005518] Wassertheil-Smoller S, Oberman A, Blaufox MD, Davis B, Langford $\mathrm{H}$. The Trial of Antihypertensive Interventions and Management (TAIM) Study. Final results with regard to blood pressure, cardiovascular risk, and quality of life [see comments]. Am J Hypertens 1992;5(1):37-44. [MEDLINE: 92144045]

Wylie-Rosett J, Wassertheil-Smoller S, Blaufox MD, Davis BR, Langford HG, Oberman A, Jennings S, Hataway H, Stern J, Zimbaldi N. Trial of antihypertensive intervention and management: greater efficacy with weight reduction than with a sodium-potassium intervention. JAm Diet Assoc 1993;93(4):408-415. [MEDLINE: 93203528]

\section{TOMHS \{published data only\}}

* Elmer PJ, Grimm R Jr, Laing B, Grandits G, Svendsen K, Van Heel N, Betz E, Raines J, Link M, Stamler J and Neaton $\mathrm{J}$ for the TOMHS Research Group. Lifestyle intervention: results of the Treatment of Mild Hypertension Study (TOMHS). Prev Med 1995;24(4):378-388. [MEDLINE: 96076094]

Neaton JD, Grimm RH Jr, Prineas RJ, et al.Treatment of mild hypertension study: final results. Journal of the American Medical Association 1993;270(6):713-724. [MEDLINE: 93329754]

Stamler J, Prineas RJ, Neaton JD, et al.Background and design of the new U.S. trial on diet and drug treatment of "mild" hypertension (TOMHS). American Journal of Cardiology 1987;59(14):51G-60G. [MEDLINE: 87238420]

Treatment of Mild Hypertension Research Group. The treatment of mild hypertension study. A randomized, placebo-controlled trial of a nutritional-hygienic regimen along with various drug monotherapies. Archives of Internal Medicine 1991;151(7):1413-1423. [MEDLINE: 91290967]

Velloso 1991 \{published data only\}

* Velloso LG, Alonso RR, Ciscato CM, Barretto AC, Bellotti G, Pileggi F. [Diet with usual quantity of salt in hospital treatment of congestive heart insufficiency]. Arq Bras Cardiol 1991;57(6):465-468. [MEDLINE: 92398510]

Watt 1983 \{published data only\} Watt GC, Edwards C, Hart JT, Hart M, Walton P, Foy CJ. Dietary sodium restriction for mild hypertension in general practice. British Medical Journal Clinical Research.Ed 1983; 286(6363):432-436. [MEDLINE: 83102255]

Watt 1986 \{published data only\}

* Watt GC, Foy CJ, Hart JT. Dietary sodium and blood pressure in young people with and without familial predisposition to high blood pressure. J Clin Hypertens 1986;2(2):141-147. [MEDLINE: 87010734]

Weinberger 1988 \{published data only\}

* Weinberger MH, Cohen SJ, Miller JZ, Luft FC, Grim CE, Fineberg NS. Dietary sodium restriction as adjunctive treatment of hypertension. JAMA 1988;259 (17):2561-2565. [MEDLINE: 88188298] 
Wing 1984 \{published data only\}

Wing RR, Caggiula AW, Nowalk MP, Koeske R, Lee $S$, Langford H. Dietary approaches to the reduction of blood pressure: the independence of weight and sodium/ potassium interventions. Preventive Medicine 1984;13(3): 233-244. [MEDLINE: 85038455]

Zoccali 1993 \{published data only\}

* Zoccali C, Mallamaci F, Leonardis D, Romeo M. Randomly allocated crossover study of various levels of sodium intake in patients with mild hypertension. J Hypertens Suppl 1993;11(Suppl 5):S326-S327.

[MEDLINE: 94210208]

\section{Additional references}

\section{Alam 1999}

Alam S, Johnson AG. A meta-analysis of randomised controlled trials (RCT) among healthy normotensive and essential hypertensive elderly patients to determine the effect of high salt $(\mathrm{NaCl})$ diet of blood pressure. J Hum Hypertens 1999;13(6):367-374. [MEDLINE: 99335071]

Alderman 1995

Alderman MH, Madhavan S, Cohen H, Sealey JE, Laragh $\mathrm{JH}$. Low urinary sodium is associated with greater risk of myocardial infarction among treated hypertensive men. Hypertension 1995;25(6):1144-1152. [MEDLINE: 95286216]

\section{Alderman 1997}

Alderman MH, Ooi WL, Cohen H, Madhavan S, Sealey JE, Laragh JH. Plasma renin activity: a risk factor for myocardial infarction in hypertensive patients. American Journal of Hypertension 1997;10(1):1-8. [MEDLINE: 97160946]

\section{Alderman 1998}

Alderman MH, Cohen H, Madhavan S. Dietary sodium intake and mortality: the National Health and Nutrition Examination Survey (NHANES I). Lancet 1998;351(9105): 781-785. [MEDLINE: 98178771]

\section{Allender 1996}

Allender PS, Cutler JA, Follmann D, Cappuccio FP, Pryer J, Elliott P. Dietary calcium and blood pressure: a metaanalysis of randomized clinical trials. Annals of Internal Medicine 1996;124(9):825-831. [MEDLINE: 96188897]

Anonymous 2000

Anonymous. Assessment of study quality. In: Clarke M, Oxman AD editor(s). Cochrane Reviewer's Handbook 4.1 [updated June 2000]. Oxford: Update Software, 2000.. Oxford: Update Software, 2000

\section{Barker 1998}

Barker DJP. Mothers, babies and health in later life. Second Edition. Edinburgh: Churchill Livingstone, 1998.

\section{Berkley 1995}

Berkey CS, Hoaglin DC, Mosteller F, Colditz GA. A random-effects regression model for meta-analysis. Statistics in Medicine 1995;14(4):395-411. [MEDLINE: 95265785]

\section{Brand 1999}

Brand MB, Mulrow CD, Chiquette E, Angel L, Cornell J, Summerbell CD, Anagnostelis B, Grimm RJ. Dieting to reduce body weight for controlling hypertension in adults. Cochrane Database of Systematic Reviews 2000, Issue 2. [DOI: 10.1002/14651858.CD000484; MEDLINE: 10796721]

Cappuccio 1991

Cappuccio FP, MacGregor GA. Does potassium supplementation lower blood pressure? A meta-analysis of published trials. Journal of Hypertension 1991;9(5): 465-473. [MEDLINE: 91311080]

Cutler 1997

Cutler JA, Follmann D, Allender PS. Randomized trials of sodium reduction: an overview. American Journal of Clinical Nutrition 1997;65(2 Suppl):643S-651S. [MEDLINE: 97174900]

\section{DoH 2001}

Department of Health. The Annual Report of the Chief Medical Officer of the Department on Health 2001. Department of Health. London, 2001.

Donner 1982

Donner A. An empirical study of cluster randomization. International Journal of Epidemiology 1982;11(3):283-286. [MEDLINE: 83029945]

\section{Ebrahim 1996}

Ebrahim S, Davey Smith G. Health promotion in older people for the prevention of coronary heart disease and stroke. London: Health Education Authority, 1996.

\section{Ebrahim 1998}

Ebrahim S, Davey Smith G. Lowering blood pressure: a systematic review of sustained effects of nonpharmacological interventions. Journal of Public Health Medicine 1998;20(4):441-448. [MEDLINE: 99120827]

Elliott 1996

Elliott P, Stamler J, Nichols R, Dyer AR, Stamler R, Kesteloot $\mathrm{H}$, Marmot M. Intersalt revisited: further analyses of 24 hour sodium excretion and blood pressure within and across populations. Intersalt Cooperative Research Group. [erratum appears in BMJ 1997 Aug 23;315(7106): 458.].. BMJ 1996;312(7041):1249-1253. [MEDLINE: $96225304]$

Follman 1992

Follman D, Elliott P, Suh I, Cutler J. Variance imputation for overviews of clinical trails with continuous response. J Clin Epidemiol 1992;45(7):769-773. [MEDLINE: 92317975]

\section{Graudal 1998}

Graudal NA, Galloe AM, Garred P. Effects of sodium restriction on blood pressure, renin, aldosterone, catecholamines, cholesterols and triglyceride: a metaanalysis.. JAMA 1998;279(17):1383-1391. [MEDLINE: 98241203]

\section{Griffith 1999}

Griffith LE, Guyatt GH, Cook RJ, Bucher HC, Cook DJ. The influence of dietary and non-dietary 
calcium supplementation on blood pressure. An updated metaanalysis of randomized controlled trials. American Journal of Hypertension 1999;12(1 Pt 1):84-92. [MEDLINE: 99173714]

\section{Hauck 1991}

Hauck WW, Gilliss CL, Donner A, Gortner S.

Randomization by cluster. Nursing Research 1991;40(6): 356-358. [MEDLINE: 92066521]

He 1999

He J, Ogden LG, Vupputuri S, Bazzano LA, Loria C, Whelton PK. Dietary sodium intake and subsequent risk of cardiovascular disease in overweight adults. JAMA 1999; 282(21):2027-2034. [MEDLINE: 20057342]

\section{He 2001}

He FJ, MacGregor GA. Neonatal salt intake and blood pressure. Lancet 2001;357(9271):1880. [MEDLINE: 21307932]

Hofman 1983

Hofman A, Hazebroek A, Valkenburg HA. A randomized trial of sodium intake and blood pressure in newborn infants. JAMA 1983;250(3):370-373. [MEDLINE: 83216582]

\section{Hooper 2000}

Hooper L, Summerbell CD, Higgins JPT, Thompson RL, Clements G, Capps N, Davey Smith G, Riemersma RA, Ebrahim S. Reduced or modified dietary fat for preventing cardiovascular disease. Cochrane Database of Systematic Reviews 2000, Issue 2. [DOI: 10.1002/ 14651858.CD002137]

\section{Jurgens 2003}

Jurgens G, Graudal NA. Effects of low sodium diet versus high sodium diet on blood pressure, renin, aldosterone, catecholamines, cholesterols, and triglyceride. Cochrane Database of Systematic Reviews 2003, Issue 4. [DOI: 10.1002/14651858.CD004022.pub2]

Law 1991

Law MR, Frost CD, Wald NJ. By how much does dietary salt reduction lower blood pressure? III--Analysis of data from trials of salt reduction. [erratum appears in BMJ 1991 Apr 20;302(6782):939.].. BMJ 1991;302(6780):819-824. [MEDLINE: 91223292]

Lucas 1988

Lucas A, Morley R, Husdon GJ, Bamford MF, Boon A, Crowle P, Dossetor JF, Pearse R. Early sodium intake and later blood pressure in preterm infants. Archives of Disease in Childhood 1988;63(6):656-657. [MEDLINE: 88268226]

\section{MacGregor 1996}

MacGregor GA, Sever PS. Salt -- overwhelming evidence but still no action: can a consensus be reached with the food industry? CASH (Consensus Action on Salt and Hypertension).. BMJ 1996;312(7041):1287-1289. [MEDLINE: 96225315]

\section{MAFF 1999}

MAFF. National Food Survey, 1998. Annual report of food expenditure, consumption and nutrient intakes. London: HMSO, 1999.

\section{Midgley 1996}

Midgley JP, Matthew AG, Greenwood CM, Logan AG. Effect of reduced dietary sodium on blood pressure: a metaanalysis of randomized controlled trials. JAMA 1996;275 (20):1590-1597. [MEDLINE: 96213904]

\section{Navar 1997}

Navar LG. The kidney in blood pressure regulation and development of hypertension. Medical Clinics of North America 1997;81(5):1165-1198. [MEDLINE: 97453984]

\section{Ramsay 1999}

Ramsay LE, Williams B, Johnston GD, MacGregor GA, Poston L, Potter JF, Poulter NR, Russell G. British Hypertension Society guidelines for hypertension management 1999: summary. BMJ 1999;319(7210): 630-635. [MEDLINE: 99402837]

\section{Ramsay 1999a}

Ramsay L, Williams B, Johnston G, MacGregor G, Poston L, Potter J, Poulter N, Russell G. Guidelines for management of hypertension: report of the third working party of the British Hypertension Society. Journal of Human Hypertension 1999;13(9):569-592. [MEDLINE: 99414258]

\section{Sacks 2001}

Sacks FM, Svetkey LP, Vollmer WM, Appel LJ, Bray GA, Harsha D, Obarzanek E, Conlin PR, Miller ERI, SimonsMorton DG, Karanja N, Lin P-H, Aickin M, MostWindhauser MM, Moore TJ, Proschan MA, Cutler JA. Effects on blood pressure of reduced dietary sodium and the Dietary Approaches to Stop Hypertension (DASH) diet. DASH-Sodium Collaborative Research Group. New England Journal of Medicine 2001;344(1):3-10. [MEDLINE: 21012263]

\section{Selmer 2000}

Selmer RM, Kristiansen IS, Haglerod A, Graff-Iverson S, Larsen HK, Meyer HE, Bonaa KH, Thelle DS. Cost and health consequences of reducing the population intake of salt. Journal of Epidemiology and Community Health 2000; 54(9):697-702. [MEDLINE: 20400582]

\section{Sharp 1998}

Sharp S. Meta-analysis regression. Stata Technical Bulletin 1998;42:16-22. [: ISBN 1-881228-31-2]

\section{Singhal 2001}

Singhal A, Cole TJ, Lucas A. Early nutrition in preterm infants and later blood pressure: two cohorts after randomised trials. Lancet 2001;357(9254):413-419. [MEDLINE: 21119870]

Stamler 1991

Stamler R. Implications of the INTERSALT study. Hypertension 1991;17(1 suppl):I 16-I 20. [MEDLINE: 91099886]

Taubes 1998 Taubes G. The (political) science of salt. Science 1998;281 (5379):898-907. [MEDLINE: 98383455]

\section{Tunstall-Pedoe 1997}

Tunstall-Pedoe H, Woodward M, Tavendale R, A'Brook $\mathrm{R}$, McCluskey MK. Comparison of the prediction by 27 
different factors of coronary heart disease and death in men and women of the Scottish heart health study: cohort study. [erratum appears in BMJ 1998 Jun 20;316(7148):1881.].. BMJ 1997;315(7110):722-729. [MEDLINE: 97460376]

Tuomilehto 2001

Tuomilehto J, Jousilahti P, Rastenyte D, Moltchanov V, Tanskanen A, Pietinen P, Nissinen A. Urinary sodium excretion and cardiovascular mortality in Finland: a prospective study. Lancet 2001;357(9259):848-851. [MEDLINE: 21163719]

\section{Whelton 1997}

Whelton PK, He J, Cutler JA, Brancati FL, Appel LJ, Follmann D, Klag MJ. Effects of oral potassium on blood pressure. Meta-analysis of randomized controlled clinical trials. Journal of the American Medical Association 1997;277 (20):1624-1632. [MEDLINE: 97311576]

\section{References to other published versions of this review}

\section{Hooper 2002}

Hooper L, Bartlett C, Davey Smith G, Ebrahim S. Longer electronic version of this review on BMJ website, http:// bmj.com/ [Systematic review of long term effects of advice to reduce dietary salt in adults]. British Medical Journal 2002;325(7365):628-632. [: EMBASE Accession Number is 2002347601]

* Indicates the major publication for the study 


\section{CHARACTERISTICS OF STUDIES}

\section{Characteristics of included studies [ordered by study ID]}

\section{Alli 1992}

\begin{tabular}{ll} 
Methods & $\begin{array}{l}\text { RCT: GPs were 'selected at random' (GPs were randomised, not participants, } 9 \text { gave dietary advice and } \\
10 \text { did not) }\end{array}$ \\
\hline Participants & $\begin{array}{l}\text { Untreated hypertensives, Italy, mean age } 48 \text { years, } 42 \% \text { male, ?\% white, BMI }<30 . \\
\text { Inclusion criteria: DBP } 90-104 \mathrm{mmHg} \text { over } 6 \text { weeks, not on AHTM }\end{array}$ \\
\hline Interventions & $\begin{array}{l}\text { LS: received low sodium dietary advice (individual counselling by GP, reinforced at each clinic visit. Main } \\
\text { messages (leaflet) don't add salt at table or in cooking, restrict salty processed foods, eat more fresh/ frozen } \\
\text { foods and seasoning advice), USE Target: }<=80, \\
\text { C maintained usual diet }\end{array}$ \\
\hline Outcomes & BP \& USE at 1,3,6, $9 \& 12$ mo \\
\hline Notes & $\begin{array}{l}\text { PB: no. } \\
\text { OAB: no } \\
\text { AL: Losses excluded. } \\
\text { Assigned: LS } 40, \text { C } 37 \\
\text { Follow up: LS } 26, \text { C } 30(12 \mathrm{mo})\end{array}$ \\
\hline
\end{tabular}

\section{Risk of bias}

\begin{tabular}{lll}
\hline Item & Authors' judgement & Description \\
\hline Allocation concealment? & No & C - Inadequate \\
\hline
\end{tabular}

\section{Arroll 1995}

\begin{tabular}{|c|c|}
\hline Methods & RCT: 'factorial type RCT design'. \\
\hline Participants & $\begin{array}{l}\text { Treated hypertensives, New Zealand, mean age } 55 \text { years, } 52 \% \text { male, ?\% white. } \\
\text { Inclusion criteria: AHTM treated hypertension (DBP > } 70 \text { to } 105 \mathrm{mmHg} \text { or SBP >155 to } 180 \mathrm{mmHg} \text { ) }\end{array}$ \\
\hline Interventions & $\begin{array}{l}\text { LS: on medication, asked to reduce use of high salt foods, salt added at table and in cooking (led by whom? } \\
\text {, group or individual?). Each given an article on BP and salt restriction, a leaflet and a book with the Na } \\
\text { content of common foods, USE Target: Not specified, } \\
\text { C: on medication, no intervention }\end{array}$ \\
\hline Outcomes & BP \& AHTM levels following withdrawal of AHTM at 0 and 6 mo, USE at 6 mo \\
\hline Notes & $\begin{array}{l}\text { PB: no } \\
\text { OAB: yes } \\
\text { AL: Losses excluded from BP measurement. No adjustment made for those who decreased or stopped } \\
\text { medication }\end{array}$ \\
\hline
\end{tabular}


Arroll 1995 (Continued)

Assigned: LS 51, C 49

Follow up: LS 44, C 43 (6 mo)

\section{Risk of bias}

\begin{tabular}{lll}
\hline Item & Authors' judgement & Description \\
\hline Allocation concealment? & Unclear & B - Unclear \\
\hline
\end{tabular}

\section{Costa 1981}

\begin{tabular}{|c|c|}
\hline Methods & RCT: 'randomly divided into 2 groups'. \\
\hline Participants & $\begin{array}{l}\text { Untreated hypertensives, Italy, age range } 16-31 \text { years, ?\% male, ?\% white. } \\
\text { Inclusion criteria: untreated borderline hypertension }\end{array}$ \\
\hline Interventions & $\begin{array}{l}\text { LS: given a low salt diet (no data on who gave advice, group or individual counselling, materials used, or } \\
\text { main messages), Target: } 3 \mathrm{~g} \mathrm{NaCl} / \text { day, } \\
\text { C: advised on diet with free salt intake }\end{array}$ \\
\hline Outcomes & BP \& intra-lymphocytic sodium at $0 \& 12 \mathrm{mo}$ \\
\hline Notes & $\begin{array}{l}\text { PB: no. } \\
\text { OAB: unclear. } \\
\text { AL: Not specified. } \\
\text { Assigned: LS 21, C } 20 \\
\text { Follow up: LS 20, C } 21 \text { (sic) }\end{array}$ \\
\hline
\end{tabular}

\section{Risk of bias}

\begin{tabular}{|c|c|c|}
\hline Item & Authors' judgement & Description \\
\hline Allocation concealment? & Unclear & B - Unclear \\
\hline
\end{tabular}

HPT

Methods

Participants

Interventions
RCT: randomisation code 'centrally generated by computer'.

Normotensives, USA, mean age 39 years, $62 \%$ male, $84 \%$ white. Inclusion criteria: high normotensive, DBP 78-89, not on AHTM

LS: on dietary and behavioural change programme (led by personnel trained and experienced in effecting behaviour change related to food, group sessions with individual counselling if sessions missed, newsletter between sessions, self assessment, goal setting, participant manual, food counter, cookbook, food demonstrations and tasting, team building exercises, tokens of accomplishment), USE Target: $</=70$,

C: no dietary counselling 


\begin{tabular}{|c|c|c|}
\hline Outcomes & \multicolumn{2}{|c|}{ BP \& USE at $0,6, \& 36 \mathrm{mo}, \%$ on anti-hypertensive medication } \\
\hline Notes & \multicolumn{2}{|c|}{$\begin{array}{l}\text { PB: no } \\
\text { OAB: yes } \\
\text { AL: Participants with no follow-ups excluded; others given reading from last visit (or treated BP if higher) } \\
\text { Assigned: LS 196, C } 196 \\
\text { Follow up: LS 174, C } 191(6 \mathrm{mo}) \text {, LS 175, C } 178(36 \mathrm{mo})\end{array}$} \\
\hline \multicolumn{3}{|l|}{ Risk of bias } \\
\hline Item & Authors' judgement & Description \\
\hline Allocation concealment? & Yes & A - Adequate \\
\hline
\end{tabular}

\section{Morgan 1978}

\begin{tabular}{|c|c|c|}
\hline Methods & \multicolumn{2}{|c|}{ RCT: 'were divided randomly into 4 subgroups'. } \\
\hline Participants & \multicolumn{2}{|c|}{$\begin{array}{l}\text { Untreated hypertensives, Australia, }>50 \text { years, } 100 \% \text { male, ethnicity not stated. } \\
\text { Inclusion criteria: borderline hypertension, no AHTM (DBP } 95-109 \mathrm{mmHg} \text { as a mean of } 2 \text { or } 4 \text { readings) }\end{array}$} \\
\hline Interventions & \multicolumn{2}{|c|}{$\begin{array}{l}\text { LS: instructed to reduce their dietary sodium chloride intake, advice repeated at } 3 \text { months (no data on } \\
\text { who gave advice, group or individual counselling, materials used, or main messages), DSI Target: 70-100, } \\
\text { C: no dietary treatment, reviewed } 6 \text { monthly as LS group }\end{array}$} \\
\hline Outcomes & \multicolumn{2}{|c|}{$\mathrm{BP} \& \mathrm{USE}$ at $0,6,12,18,24 \mathrm{mo}$} \\
\hline Notes & \multicolumn{2}{|c|}{$\begin{array}{l}\text { PB: no. } \\
\text { OAB: yes } \\
\text { AL: Those with no follow-up excluded. Reading at last visit used for remainder. } \\
\text { Assigned: LS 34, C } 33 \text { for BP (LS 35, C } 42 \text { for mortality) } \\
\text { Follow up: LS 26, C } 21 \text { ( } 24 \text { mo) (all followed re mortality) }\end{array}$} \\
\hline \multicolumn{3}{|l|}{ Risk of bias } \\
\hline Item & Authors' judgement & Description \\
\hline Allocation concealment? & Unclear & B - Unclear \\
\hline
\end{tabular}


Morgan 1987

\begin{tabular}{l|l}
\hline Methods & RCT: 'randomised in blocks of 4' \\
\hline Participants & $\begin{array}{l}\text { Treated hypertensives, Australia, mean age } 61 \text { years, } 100 \% \text { male, ?\% white. } \\
\text { Inclusion criteria: hypertension (DBP }<85 \mathrm{mmHg} \text { ) while on AHTM (DBP }>100 \text { uncontrolled) }\end{array}$ \\
\hline Interventions & $\begin{array}{l}\text { LS: withdrawal of AHTM after } 3 \text { months on low sodium diet (led by whom?, no details of programme), } \\
\text { DSI Target: } 50-75, \\
\text { C: withdrawal of anti-hypertensives after } 3 \text { months, maintained normal diet }\end{array}$ \\
\hline Outcomes & Necessity to restart AHTM following withdrawal, USE at 0 \& 9 mo \\
\hline Notes & $\begin{array}{l}\text { PB: no. } \\
\text { OAB: yes } \\
\text { AL: Last BP reading before reinstatement was used; all had at least one follow-up. } \\
\text { Assigned: LS } 10, \text { C } 10 \\
\text { Follow up: LS } 10, \text { C } 10 \text { (9 mo) }\end{array}$ \\
\hline Risk of bias & \begin{tabular}{l} 
Allocation concealment? \\
\hline Unclear
\end{tabular} \\
\hline
\end{tabular}

Silman 1983

\begin{tabular}{|c|c|c|}
\hline Methods & \multicolumn{2}{|c|}{ RCT: 'randomisation after stratification by practice'. } \\
\hline Participants & \multicolumn{2}{|c|}{$\begin{array}{l}\text { Untreated hypertensives, UK, aged } 50 \text { to } 64, ? \% \text { male, ?\% white. } \\
\text { Inclusion criteria: hypertension (DBP } 95-104 \mathrm{mmHg} \text { over one year) }\end{array}$} \\
\hline Interventions & \multicolumn{2}{|c|}{$\begin{array}{l}\text { LS: general health education group package with spouses (eating sensibly, stopping smoking, regular } \\
\text { exercise, stress avoidance) plus taught diet (diet sheet given) lead by researcher, USE Target: } 100 \text {, } \\
\text { C: general health education group package only }\end{array}$} \\
\hline Outcomes & \multicolumn{2}{|c|}{ BP \& USE at $0,1,2,3,6 \& 12 \mathrm{mo}$} \\
\hline Notes & \multicolumn{2}{|c|}{$\begin{array}{l}\text { PB: no, } \\
\text { OAB: unclear. } \\
\text { AL: Losses excluded. Baseline readings for "excluded" compared with those for "included". } \\
\text { Assigned: LS 12, C } 16 \\
\text { Follow up: LS 10, C } 15 \text { (12 mo) }\end{array}$} \\
\hline \multicolumn{3}{|l|}{ Risk of bias } \\
\hline Item & Authors' judgement & Description \\
\hline Allocation concealment? & Unclear & B - Unclear \\
\hline
\end{tabular}

Advice to reduce dietary salt for prevention of cardiovascular disease (Review) 
Thaler men 1982

\begin{tabular}{|c|c|}
\hline Methods & $\begin{array}{l}\text { RCT: index subjects were subdivided into two groups in such a way that the following factors were kept } \\
\text { balanced: sex, decade of age, SBP, AHTM, number of index persons per family, number of other persons } \\
\text { in family. The two groups were randomly assigned to control and salt restriction respectively' }\end{array}$ \\
\hline Participants & $\begin{array}{l}\text { Untreated hypertensives, New Zealand, mean age } 41 \text { years, } 48 \% \text { male, ethnicity not stated. } \\
\text { Inclusion criteria: For index subjects, SBP } 137-180 \mathrm{mmHg} \text {, some (21\%) on AHTM. Family members } \\
\text { also included }\end{array}$ \\
\hline Interventions & $\begin{array}{l}\text { LS: salt restriction programme for the whole family (led by a nutritionist, gradually introduced, individual } \\
\text { counselling, some at the family home, main messages to stop adding salt, cut out salt in cooking and } \\
\text { restrict high sodium foods, low sodium baking powder and baking soda were provided and a local baker } \\
\text { made low sodium bread, cookbook provided), USE Target: not stated, } \\
\text { C: asked to eat usual diet }\end{array}$ \\
\hline Outcomes & USE at $0 \& 8 \mathrm{mo}$ \\
\hline Notes & $\begin{array}{l}\text { PB: no. } \\
\text { OAB: unclear. } \\
\text { AL: losses excluded. } \\
\text { Assigned: LS } 80 \text { ( } 38 \text { index }+42 \text { family), C } 84 \text { ( } 39 \text { index }+45 \text { family) } \\
\text { Follow up: LS } 69 \text { ( } 37 \text { index, } 19 \text { men \& } 18 \text { women), C } 67 \text { ( } 35 \text { index, } 17 \text { men \& } 18 \text { women) ( } 8 \text { mo) }\end{array}$ \\
\hline \multicolumn{2}{|l|}{ Risk of bias } \\
\hline Item & Authors' judgement \\
\hline Allocation concealment? & B - Unclear \\
\hline
\end{tabular}

Thaler women 1982

\begin{tabular}{|c|c|c|}
\hline Methods & \multicolumn{2}{|l|}{ as Thaler men } \\
\hline Participants & \multicolumn{2}{|l|}{ as Thaler men } \\
\hline Interventions & \multicolumn{2}{|l|}{ as Thaler men } \\
\hline Outcomes & \multicolumn{2}{|l|}{ as Thaler men } \\
\hline Notes & \multicolumn{2}{|l|}{ as Thaler men } \\
\hline \multicolumn{3}{|l|}{ Risk of bias } \\
\hline Item & Authors' judgement & Description \\
\hline Allocation concealment? & Unclear & B - Unclear \\
\hline
\end{tabular}


TOHP phase I

\begin{tabular}{|c|c|c|}
\hline Methods & \multicolumn{2}{|c|}{$\begin{array}{l}\text { RCT: 'randomisation assignments were obtained from the co-ordinating center by telephone... when } \\
\text { telephone contact not possible sealed opaque envelopes were used' }\end{array}$} \\
\hline Participants & \multicolumn{2}{|c|}{$\begin{array}{l}\text { Normotensives, USA, mean age } 43 \text { years, } 71 \% \text { male, } 77 \% \text { white. } \\
\text { Inclusion criteria: High normal (DBP } 80 \text { to } 89 \mathrm{mmHg} \text { over } 9 \text { readings), not on AHTM }\end{array}$} \\
\hline Interventions & \multicolumn{2}{|c|}{$\begin{array}{l}\text { Regimen: LS group nutrition and behavioural counselling programme (led by nutritionists, including } \\
\text { food tasting and samples, problem solving exercises, shopping lists and guides, peer support and family } \\
\text { involvement, field trips to shops and restaurants, motivational activities, food diaries and self assessment } \\
\text { of sodium intake), USE Target: } 80 \text {, } \\
\text { C: no intervention }\end{array}$} \\
\hline Outcomes & \multicolumn{2}{|c|}{ BP \& USE at $0,6,12 \& 18 \mathrm{mo}$} \\
\hline Notes & \multicolumn{2}{|c|}{$\begin{array}{l}\text { PB: no } \\
\text { OAB: yes } \\
\text { AL: Participants with no follow-up reading taken as zero change; others given reading from last visit. } \\
\text { Assigned: LS } 327, \text { C } 417 \\
\text { Follow up: LS 301, C } 392 \text { ( } 12 \mathrm{mo}) \text {, } \\
\text { LS 304, C } 395 \text { ( } 18 \mathrm{mo})\end{array}$} \\
\hline \multicolumn{3}{|l|}{ Risk of bias } \\
\hline Item & Authors' judgement & Description \\
\hline Allocation concealment? & Yes & A - Adequate \\
\hline
\end{tabular}

\section{TOHP phase II}

\begin{tabular}{|c|c|}
\hline Methods & RCT: by telephone to TOHP co-ordinating center or sealed, opaque envelope \\
\hline Participants & $\begin{array}{l}\text { Normotensives, USA, mean age } 44 \text { years, } 67 \% \text { male, } 81 \% \text { white. } \\
\text { Inclusion criteria: High normal (DBP } 83 \text { to } 89 \mathrm{mmHg}, \mathrm{SBP}<=140 \mathrm{mmHg} \text { ), not on AHTM. (People } \\
\text { unwilling to comply with intervention excluded.) }\end{array}$ \\
\hline Interventions & $\begin{array}{l}\text { LS: dietary and behavioural change programme (led by dietitians, psychologists and health counselors, } \\
\text { programme as TOHP I with individual counselling as well as group sessions) intensive early on, contact } \\
\text { maintained later, USE Target: 70, } \\
\text { C: no active intervention }\end{array}$ \\
\hline Outcomes & BP \& USE at $0,6,18 \& 36$ mo ( 42 or 48 mo sometimes) \\
\hline Notes & $\begin{array}{l}\text { PB: no. } \\
\text { OAB: yes } \\
\text { AL: Those with no follow-up reading given random value from range of results; others given reading from } \\
\text { last visit. } \\
\text { Assigned: LS 594, C } 596 \\
\text { Follow up: LS 529, C } 538 \text { (6 mo), LS 515, C } 514(36 \mathrm{mo})\end{array}$ \\
\hline
\end{tabular}


TOHP phase II (Continued)

Risk of bias

\begin{tabular}{l|ll}
\hline Item & Authors' judgement & Description \\
\hline Allocation concealment? & Yes & A - Adequate \\
\hline
\end{tabular}

TONE

Methods $\quad$ RCT: 'using a computer program each participants elegibility was confirmed prior to enrollment in the trial, randomisation was stratified by clinic and weight status'

Participants Treated hypertensives, USA, mean age 67 years, $49 \%$ male, $76 \%$ white.

Inclusion criteria: AHTM-treated HT (DBP $<85 \mathrm{mmHg}, \mathrm{SBP}<145 \mathrm{mmHg})$

Interventions $\quad$ LS: attempted withdrawal of AHTM, group plus individual nutrition and behavioural counselling programme (led by nutritionists), USE Target: $<80$,

C: attempted withdrawal of anti-hypertensives, no counselling but invited to meetings on unrelated topics

Outcomes Combined BP, use of AHTM \& CV events. USE at $0,9,18 \& 30$ mo

Notes $\quad$ PB: no.

OAB: yes

AL: Used survival analysis with censoring to project proportions free of endpoints.

Assigned: LS 340, C 341

Follow up: LS 310, C 314 (30 mo)

\section{Risk of bias}

\begin{tabular}{lll}
\hline Item & Authors' judgement & Description \\
\hline Allocation concealment? & Yes & A - Adequate \\
\hline
\end{tabular}

$\mathrm{LS}=$ low salt or intervention group, $\mathrm{C}=$ control group, $\mathrm{AHTM}=$ anti-hypertensive medication, $\mathrm{BP}=\mathrm{blood}$ pressure, in $\mathrm{mmHg}$, $\mathrm{SBP}=$ systolic blood pressure, in $\mathrm{mmHg}, \mathrm{DBP}=$ diastolic blood pressure, in $\mathrm{mmHg}, \mathrm{HT}=$ hypertension, USE = urinary sodium excretion, in $\mathrm{mmol} / 24$ hours, DSI = dietary sodium intake, in $\mathrm{mmol} / 24$ hours, $\mathrm{Mo}=$ months, $\mathrm{CV}=$ cardiovascular, $\mathrm{AC}=$ allocation concealment, $\mathrm{PB}=$ participants blinded?, $\mathrm{OAB}=$ outcome assessors blinded?, $\mathrm{AL}=$ adjustment for losses 
Characteristics of excluded studies [ordered by study ID]

\begin{tabular}{|c|c|}
\hline Study & Reason for exclusion \\
\hline Aberg 1989 & Multifactorial management programme (dietary changes, stress management and increased physical activity) \\
\hline Ambard 1904 & Not randomised. \\
\hline Ambrosioni 1982 & Less than 6 months follow up from initial intervention \\
\hline Anderson 1990 & Less than 6 months follow up from initial intervention \\
\hline Berglund 1989 & Multifactorial management programme, less than 6 months follow up from initial intervention \\
\hline Bompiani 1988 & Less than 6 months follow up from initial intervention \\
\hline Cappuccio 1997 & Less than 6 months follow up from initial intervention \\
\hline Carney 1975 & Not randomised. \\
\hline Corcoran 1951 & Not randomised. \\
\hline Dahl 1958 & Not randomised. \\
\hline $\mathrm{DASH}$ & Less than 6 months follow up from initial intervention \\
\hline DISH & Multifactorial, reduces sodium intake, but also increases potassium intake \\
\hline Dole 1951 & Not randomised. \\
\hline Dubbert 1995 & Less than 6 months follow up from initial intervention \\
\hline Erwteman 1984 & Less than 6 months follow up from initial intervention \\
\hline Evers 1987 & Multifactorial management programme \\
\hline Fagerberg 1984 & Less than 6 months follow up from initial intervention \\
\hline Geleijnse 1995 & Multifactorial, reduces sodium intake, but also increases potassium intake \\
\hline Gillum 1983 & Less than 6 months follow up from initial intervention, no control group \\
\hline Grimm 1990 & All on salt restriction, no 'usual diet' control \\
\hline $\mathrm{HCP}$ & Multifactorial management programme, reduction of sodium with weight loss and alcohol reduction \\
\hline Henningsen 1980 & $\begin{array}{l}\text { Less than } 6 \text { months follow up from initial intervention (follow up between } 4 \text { and } 8 \text { months of intervention) - } \\
\text { suggests that later results will be published but none found and contact not established with the author }\end{array}$ \\
\hline
\end{tabular}

Advice to reduce dietary salt for prevention of cardiovascular disease (Review) 
(Continued)

\begin{tabular}{|c|c|}
\hline Holly 1981 & Less than 6 months follow up from initial intervention \\
\hline Iwaoka 1994 & Less than 6 months follow up from initial intervention \\
\hline Jula 1990 & Multifactorial management programme (sodium reduction with fat reduction) \\
\hline Jula $1992 a$ & Multifactorial management programme (sodium reduction with weight and fat reduction) \\
\hline Jula $1992 b$ & Multifactorial management programme (sodium reduction with weight and fat reduction) \\
\hline Jula 1994 & Multifactorial management programme (sodium reduction with weight and fat reduction) \\
\hline Koopman 1990 & The randomised part of the study only lasted 3 months, multifactorial intervention \\
\hline Korhonen 1999 & Less than 6 months follow up from initial intervention \\
\hline Logan 1986 & $\begin{array}{l}\text { Compares an intensive intervention with a less intensive intervention to restrict sodium intake, but no 'usual } \\
\text { diet' control group used. (This is a randomised clinical trial lasting } 6 \text { months) }\end{array}$ \\
\hline MacGregor 1982a & Not randomised. \\
\hline MacGregor 1982b & Less than 6 months follow up from initial intervention \\
\hline MacGregor 1989 & All on salt restriction, no 'usual diet' control \\
\hline Magnani 1976 & No 'usual diet' control \\
\hline McDonald 1988 & Multifactorial management programme (sodium reduction with weight and alcohol reduction) \\
\hline Morgan 1988 & Less than 6 months follow up from initial intervention \\
\hline Muhlhauser 1993 & Multifactorial management programme \\
\hline Myers 1989 & Less than 6 months follow up from initial intervention \\
\hline Nestel 1993 & Less than 6 months follow up from initial intervention \\
\hline Neyses 1985 & Children included \\
\hline Nicholson 1986 & Less than 6 months follow up from initial intervention \\
\hline Nicholson 1987 & Less than 6 months follow up from initial intervention \\
\hline Nowson 1988 & Less than 6 months follow up from initial intervention \\
\hline Nugent 1984 & Comparison of two different methods of salt restriction, no 'usual diet' control \\
\hline
\end{tabular}


(Continued)

\begin{tabular}{|c|c|}
\hline ODES & Multifactorial management programme \\
\hline Omvik 1986 & All on salt restriction, no 'usual diet' control \\
\hline Omvik 1995 & All on salt restriction, no 'usual diet' control \\
\hline Parijs 1973 & Not randomised. \\
\hline Perera 1947 & Not randomised. \\
\hline Priddle 1962 & Not randomised. \\
\hline Rissanen 1985 & No 'usual diet' controls \\
\hline Roca-Cusachs 1991 & Multifactorial management programme, reduces sodium and also reduces weight, fat and alcohol \\
\hline Sagnella 1987 & Less than 6 months follow up from initial intervention \\
\hline Shibata 1979 & Not randomised. \\
\hline Singer 1984 & Less than 6 months follow up from initial intervention \\
\hline Singer 1995 & Less than 6 months follow up from initial intervention \\
\hline Stamler 1989 & Multifactorial management programme, reduces sodium as well as weight and alcohol with increased exercise \\
\hline TAIM & Multifactorial, reduces sodium intake, but also increases potassium intake \\
\hline TOMHS & All on salt restriction, no 'usual diet' control \\
\hline Velloso 1991 & Less than 6 months follow up from initial intervention \\
\hline Watt 1983 & Less than 6 months follow up from initial intervention \\
\hline Watt 1986 & Less than 6 months follow up from initial intervention \\
\hline Weinberger 1988 & All on salt restriction, no 'usual diet' control. Less than 6 months follow up from initial intervention \\
\hline Wing 1984 & Less than 6 months follow up from initial intervention \\
\hline Zoccali 1993 & Less than 6 months follow up from initial intervention \\
\hline
\end{tabular}


DATA AND ANALYSES

Comparison 1. Mortality and cardiovascular morbidity

\begin{tabular}{lcccc} 
Outcome or subgroup title & $\begin{array}{c}\text { No. of } \\
\text { studies }\end{array}$ & $\begin{array}{c}\text { No. of } \\
\text { participants }\end{array}$ & Statistical method & Effect size \\
\hline 1 Mortality & 4 & 2393 & Risk Ratio (M-H, Random, 95\% CI) & $0.90[0.36,2.24]$ \\
2 Cardiovascular morbidity & 2 & 748 & Risk Ratio (M-H, Random, 95\% CI) & $0.82[0.56,1.21]$ \\
\hline
\end{tabular}

\section{Comparison 2. Systolic blood pressure}

\begin{tabular}{lcclc} 
Outcome or subgroup title & $\begin{array}{c}\text { No. of } \\
\text { studies }\end{array}$ & $\begin{array}{c}\text { No. of } \\
\text { participants }\end{array}$ & \multicolumn{1}{c}{ Statistical method } & Effect size \\
\hline $\begin{array}{l}\text { 1 Trials with 6 to 12 months of } \\
\text { follow up }\end{array}$ & 7 & 2303 & Mean Difference (IV, Random, 95\% CI) & $-2.51[-3.82,-1.21]$ \\
$\quad \begin{array}{l}\text { 1.1 Normotensives } \\
\text { 1.2 Hypertensives }\end{array}$ & 3 & 2124 & Mean Difference (IV, Random, 95\% CI) & $-2.31[-3.06,-1.55]$ \\
$\begin{array}{l}\text { Trials with 13 to 60 months of } \\
\text { follow up }\end{array}$ & 4 & 179 & Mean Difference (IV, Random, 95\% CI) & $-8.01[-15.78,-0.24]$ \\
$\quad \begin{array}{l}\text { 2.1 Normotensives } \\
\text { 2.2 Hypertensives }\end{array}$ & 3 & 2347 & Mean Difference (IV, Random, 95\% CI) & $-1.12[-1.83,-0.41]$ \\
3 Trials with more than 60 months \\
$\quad 1$
\end{tabular}

\section{Comparison 3. Diastolic blood pressure}

\begin{tabular}{|c|c|c|c|c|}
\hline Outcome or subgroup title & $\begin{array}{l}\text { No. of } \\
\text { studies }\end{array}$ & $\begin{array}{c}\text { No. of } \\
\text { participants }\end{array}$ & Statistical method & Effect size \\
\hline $\begin{array}{l}1 \text { Trials with } 6 \text { to } 12 \text { months of } \\
\text { follow up }\end{array}$ & 5 & 2211 & Mean Difference (IV, Random, 95\% CI) & $-1.21[-1.84,-0.59]$ \\
\hline 1.1 Normotensives & 3 & 2124 & Mean Difference (IV, Random, 95\% CI) & $-1.16[-1.77,-0.56]$ \\
\hline 1.2 Hypertensives & 2 & 87 & Mean Difference (IV, Random, 95\% CI) & $-4.65[-9.33,0.04]$ \\
\hline $\begin{array}{l}2 \text { Trials with } 13 \text { to } 60 \text { months of } \\
\text { follow up }\end{array}$ & 4 & 2347 & Mean Difference (IV, Random, 95\% CI) & $-0.62[-1.54,0.31]$ \\
\hline 2.1 Normotensives & 3 & 2285 & Mean Difference (IV, Random, 95\% CI) & $-0.52[-1.05,0.01]$ \\
\hline 2.2 Hypertensives & 1 & 62 & Mean Difference (IV, Random, 95\% CI) & $-7.0[-12.53,-1.47]$ \\
\hline $\begin{array}{l}3 \text { Trials with more than } 60 \text { months } \\
\text { of follow up }\end{array}$ & 1 & 128 & Mean Difference (IV, Random, 95\% CI) & $-2.2[-4.83,0.43]$ \\
\hline 3.1 Normotensives & 1 & 128 & Mean Difference (IV, Random, 95\% CI) & $-2.2[-4.83,0.43]$ \\
\hline
\end{tabular}

Advice to reduce dietary salt for prevention of cardiovascular disease (Review) 
Comparison 4. Urinary sodium excretion

\begin{tabular}{|c|c|c|c|c|}
\hline Outcome or subgroup title & $\begin{array}{l}\text { No. of } \\
\text { studies }\end{array}$ & $\begin{array}{c}\text { No. of } \\
\text { participants }\end{array}$ & Statistical method & Effect size \\
\hline $\begin{array}{l}1 \text { Urinary sodium excretion at } \\
\text { different times following } \\
\text { intervention }\end{array}$ & 7 & & Mean Difference (IV, Random, 95\% CI) & Subtotals only \\
\hline $\begin{array}{l}1.16-12 \text { months following } \\
\text { initiation of intervention }\end{array}$ & 7 & 2166 & Mean Difference (IV, Random, 95\% CI) & $\begin{array}{l}-48.94[-65.42,-32 . \\
46]\end{array}$ \\
\hline $\begin{array}{l}1.213 \text { to } 60 \text { months following } \\
\text { initiation of intervention }\end{array}$ & 4 & 2787 & Mean Difference (IV, Random, 95\% CI) & $\begin{array}{l}-35.53[-47.22,-23 . \\
85]\end{array}$ \\
\hline $\begin{array}{l}1.3 \text { More than } 60 \text { months } \\
\text { following initiation of } \\
\text { intervention }\end{array}$ & 1 & 120 & Mean Difference (IV, Random, 95\% CI) & $10.5[-13.83,34.83]$ \\
\hline
\end{tabular}

\section{Comparison 5. Dropouts}

\begin{tabular}{lcccc} 
Outcome or subgroup title & $\begin{array}{c}\text { No. of } \\
\text { studies }\end{array}$ & $\begin{array}{c}\text { No. of } \\
\text { participants }\end{array}$ & Statistical method & Effect size \\
\hline $\begin{array}{l}1 \text { Comparison of dropouts at } \\
\text { longest follow up }\end{array}$ & 10 & 3463 & Risk Ratio (M-H, Random, 95\% CI) & $1.04[0.86,1.25]$ \\
\hline
\end{tabular}




\title{
Analysis I.I. Comparison I Mortality and cardiovascular morbidity, Outcome I Mortality.
}

Review: Advice to reduce dietary salt for prevention of cardiovascular disease

Comparison: I Mortality and cardiovascular morbidity

Outcome: | Mortality

Study or subgroup Low salt $\quad$ Control

$n / N \quad n / N$

(1)

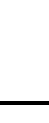

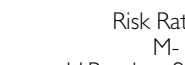

$\mathrm{M}$

H,Random, $95 \%$

HPT $\quad$ l/196 $1 / 196$

Morgan 1978

$4 / 34$

$5 / 33$

TOHP phase I

$0 / 327$

$1 / 417$

TOHP phase II

$3 / 594$

2/596

1151

1242

\begin{tabular}{l|l} 
H,Random,95\% \\
\hline \\
\hline & \\
\hline & \\
\hline & \\
\hline
\end{tabular}

Total (95\% CI)

Heterogeneity: $\mathrm{Tau}^{2}=0.0 ; \mathrm{Chi}^{2}=0.59, \mathrm{df}=3(\mathrm{P}=0.90) ; \mathrm{I}^{2}=0.0 \%$

Test for overall effect: $Z=0.22(P=0.82)$

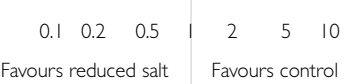

\section{Analysis I.2. Comparison I Mortality and cardiovascular morbidity, Outcome 2 Cardiovascular morbidity.}

\begin{abstract}
Review: Advice to reduce dietary salt for prevention of cardiovascular disease
\end{abstract}
Comparison: I Mortality and cardiovascular morbidity

Outcome: 2 Cardiovascular morbidity

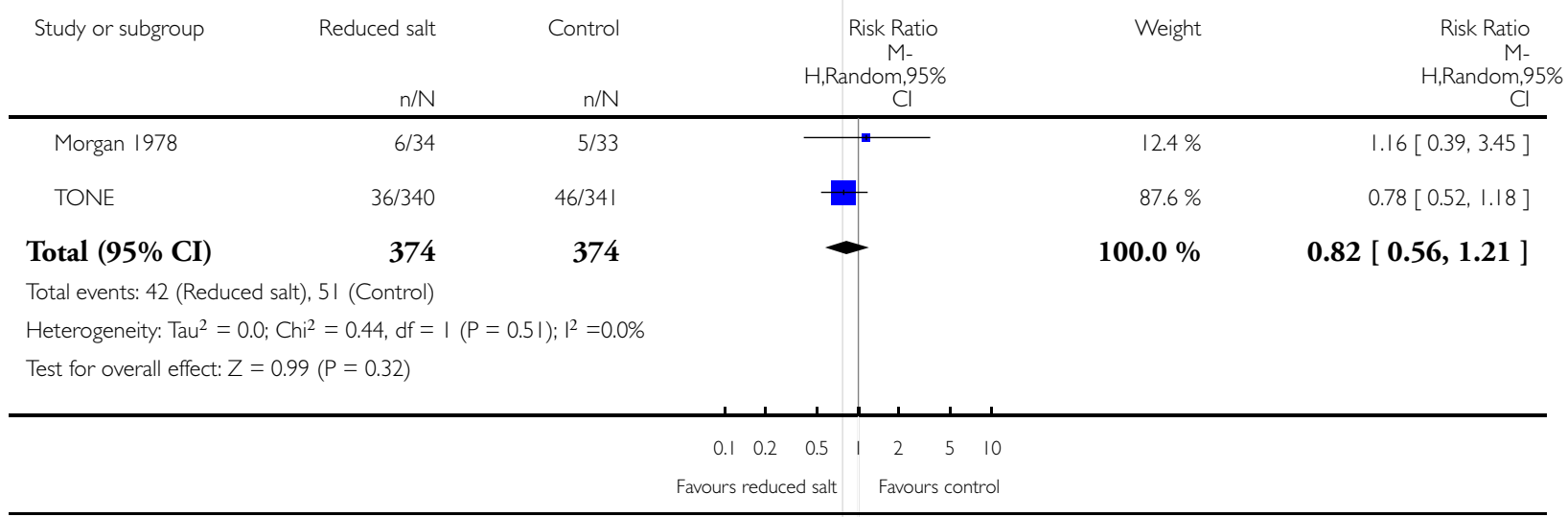

Advice to reduce dietary salt for prevention of cardiovascular disease (Review) 


\section{Analysis 2.I. Comparison 2 Systolic blood pressure, Outcome I Trials with 6 to 12 months of follow up.}

Review: Advice to reduce dietary salt for prevention of cardiovascular disease

Comparison: 2 Systolic blood pressure

Outcome: I Trials with 6 to 12 months of follow up

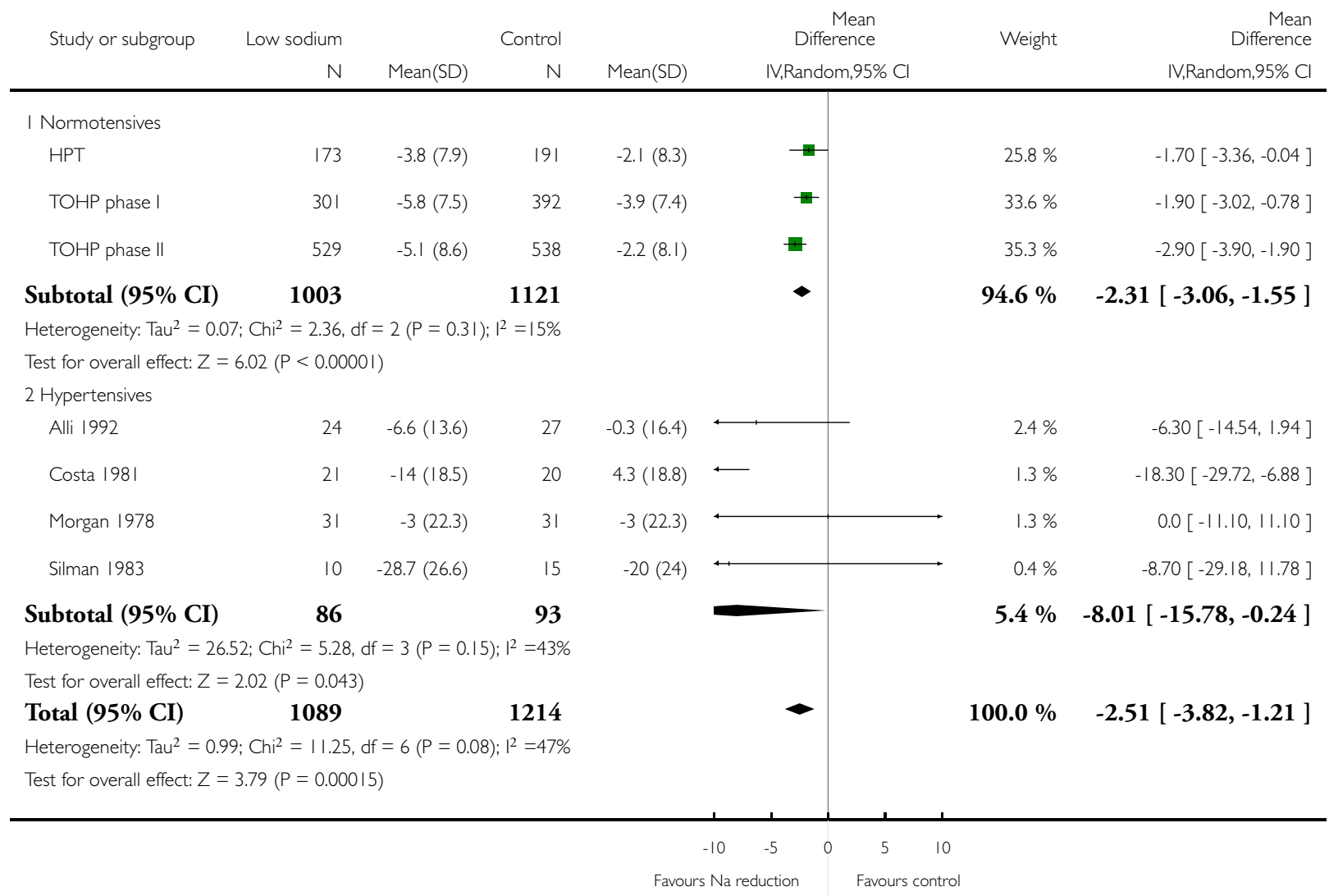




\section{Analysis 2.2. Comparison 2 Systolic blood pressure, Outcome 2 Trials with 13 to 60 months of follow up.}

Review: Advice to reduce dietary salt for prevention of cardiovascular disease

Comparison: 2 Systolic blood pressure

Outcome: 2 Trials with 13 to 60 months of follow up

\begin{tabular}{|c|c|c|c|c|c|c|c|c|c|}
\hline \multirow[t]{2}{*}{ Study or subgroup } & \multirow{2}{*}{$\begin{array}{r}\text { Low sodium } \\
N\end{array}$} & \multicolumn{3}{|c|}{ Control } & \multirow{2}{*}{\multicolumn{3}{|c|}{$\begin{array}{c}\text { Mean } \\
\text { Difference } \\
\text { IV,Random,95\% Cl }\end{array}$}} & \multirow[t]{2}{*}{ Weight } & \multirow{2}{*}{$\begin{array}{r}\text { Mean } \\
\text { Difference } \\
\text { IV,Random,95\% Cl }\end{array}$} \\
\hline & & Mean(SD) & $\mathrm{N}$ & Mean(SD) & & & & & \\
\hline \multicolumn{10}{|l|}{ I Normotensives } \\
\hline HPT & 174 & $-2.8(9.2)$ & 177 & $-2.9(9.3)$ & & $\longrightarrow$ & & $13.5 \%$ & $0.10[-1.84,2.04]$ \\
\hline TOHP phase I & 327 & $-4.9(7.8)$ & 417 & $-3.2(8.1)$ & & + & & $38.3 \%$ & $-1.70[-2.85,-0.55]$ \\
\hline TOHP phase II & 594 & $-0.7(9.2)$ & 596 & $0.3(8.9)$ & & $\rightarrow$ & & $47.8 \%$ & $-1.00[-2.03,0.03]$ \\
\hline Subtotal (95\% CI) & 1095 & & 1190 & & & $\bullet$ & & $99.6 \%$ & $-1.09[-1.92,-0.26]$ \\
\hline \multicolumn{10}{|c|}{ Heterogeneity: $\operatorname{Tau}^{2}=0.12 ; \mathrm{Chi}^{2}=2.56, \mathrm{df}=2(\mathrm{P}=0.28) ; \mathrm{I}^{2}=22 \%$} \\
\hline \multicolumn{10}{|c|}{ Test for overall effect: $Z=2.57(P=0.010)$} \\
\hline \multicolumn{10}{|l|}{2 Hypertensives } \\
\hline Morgan 1978 & 31 & $-5.5(22.3)$ & 31 & $-4(22.3)$ & $\longleftarrow$ & + & & $0.4 \%$ & $-1.50[-12.60,9.60]$ \\
\hline Subtotal (95\% CI) & 31 & & 31 & & & & & $0.4 \%$ & $-1.50[-12.60,9.60]$ \\
\hline \multicolumn{10}{|c|}{ Heterogeneity: not applicable } \\
\hline \multicolumn{10}{|c|}{ Test for overall effect: $Z=0.26(P=0.79)$} \\
\hline Total (95\% CI) & 1126 & & 1221 & & & $\bullet$ & & $100.0 \%$ & $-1.12[-1.83,-0.41]$ \\
\hline \multicolumn{10}{|c|}{ Heterogeneity: $\operatorname{Tau}^{2}=0.0 ; \mathrm{Chi}^{2}=2.56, \mathrm{df}=3(\mathrm{P}=0.46) ; \mathrm{I}^{2}=0.0 \%$} \\
\hline \multicolumn{10}{|c|}{ Test for overall effect: $Z=3.09(P=0.0020)$} \\
\hline & & & & & -10 & -5 & 5 & 10 & \\
\hline
\end{tabular}


Analysis 2.3. Comparison 2 Systolic blood pressure, Outcome 3 Trials with more than 60 months of follow up.

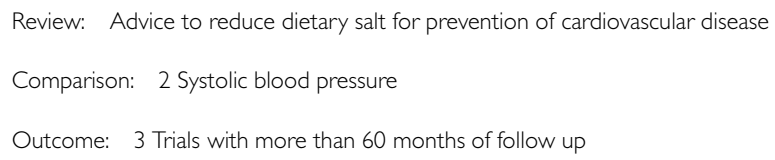

Subtotal (95\% CI)

$58 \quad 70$

Heterogeneity: not applicable

Test for overall effect: $Z=1.81(P=0.070)$

2 Hypertensives

Subtotal (95\% CI)

$\mathbf{0}$

$\mathbf{0}$

Heterogeneity: not applicable

Test for overall effect: not applicable

Total (95\% CI)

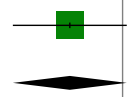

$100.0 \%-3.80[-7.91,0.31]$

Heterogeneity: not applicable

Test for overall effect: $Z=1.81(P=0.070)$

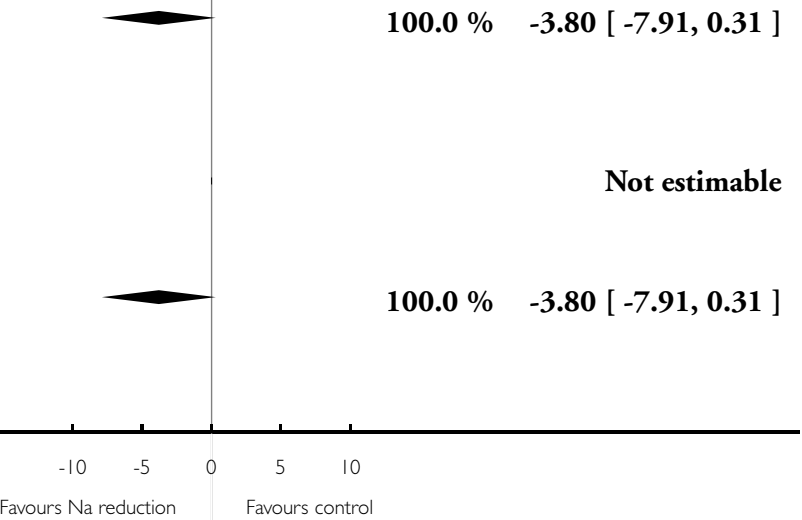




\section{Analysis 3.I. Comparison 3 Diastolic blood pressure, Outcome I Trials with 6 to 12 months of follow up.}

Review: Advice to reduce dietary salt for prevention of cardiovascular disease

Comparison: 3 Diastolic blood pressure

Outcome: I Trials with 6 to 12 months of follow up

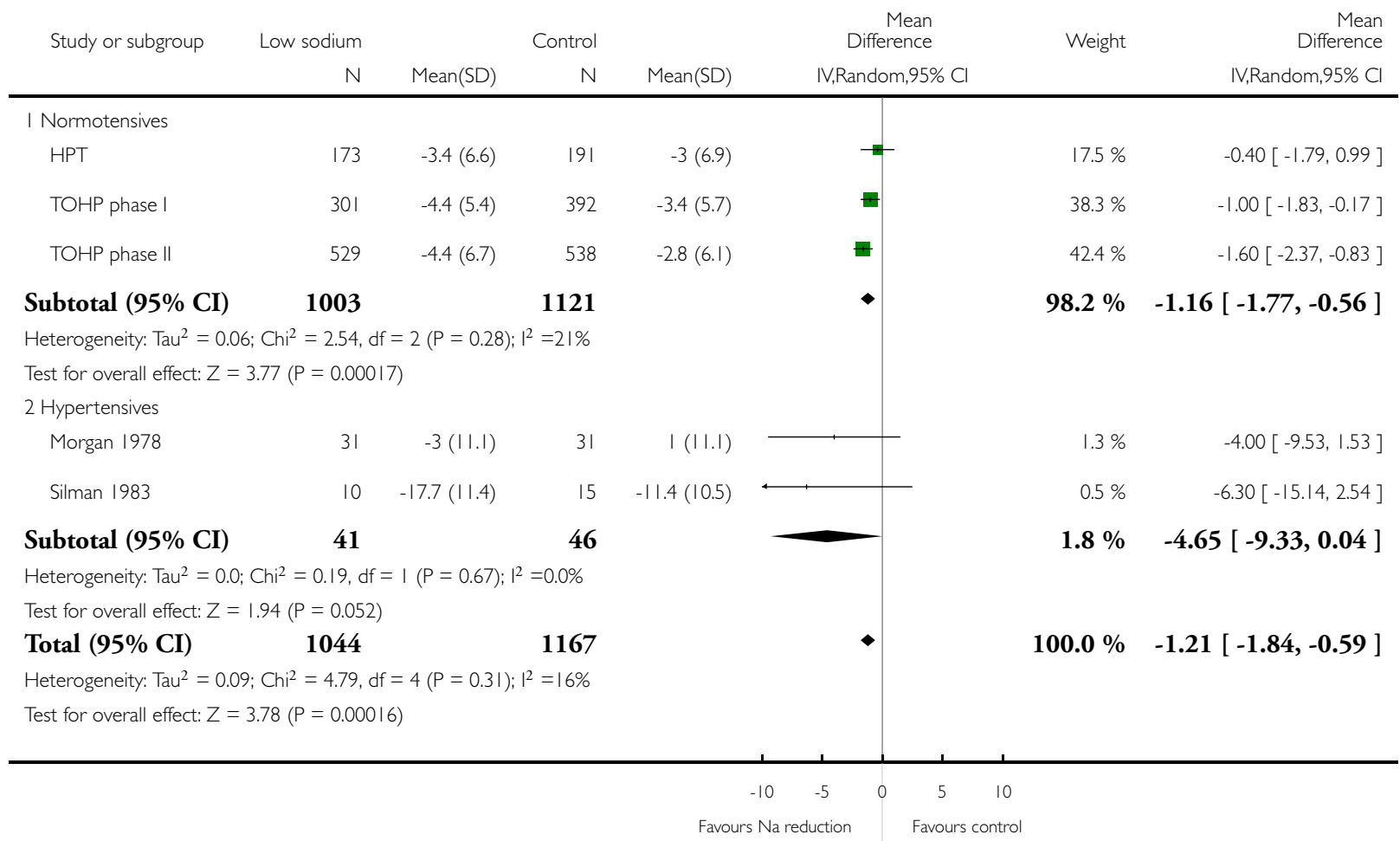


Analysis 3.2. Comparison 3 Diastolic blood pressure, Outcome 2 Trials with 13 to 60 months of follow up.

Review: Advice to reduce dietary salt for prevention of cardiovascular disease

Comparison: 3 Diastolic blood pressure

Outcome: 2 Trials with 13 to 60 months of follow up

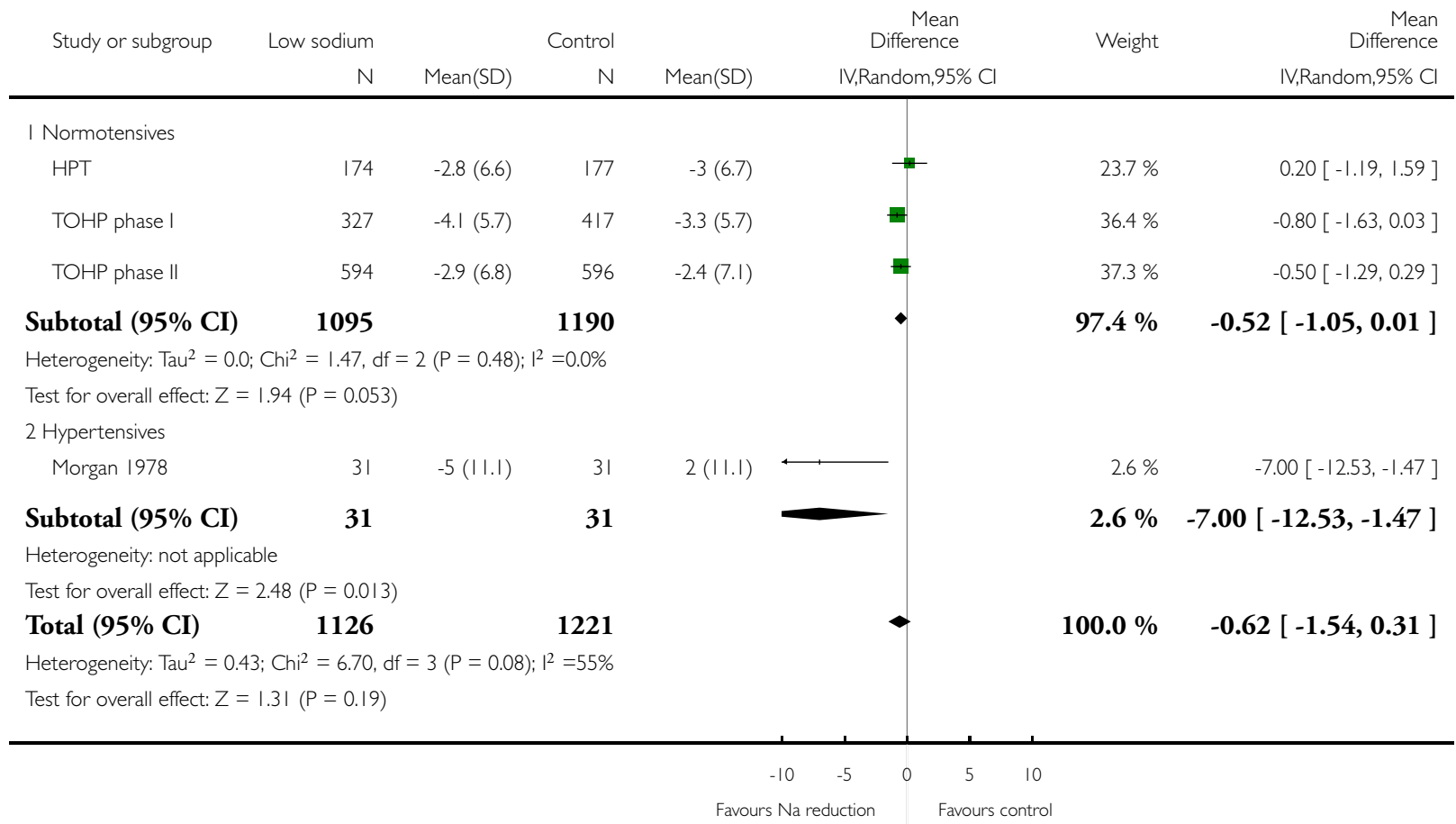


Analysis 3.3. Comparison 3 Diastolic blood pressure, Outcome 3 Trials with more than 60 months of follow up.

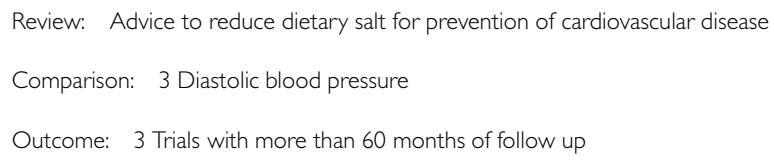

$58 \quad 70$

Heterogeneity: not applicable

Test for overall effect: $Z=1.64(P=0.10)$

2 Hypertensives

Subtotal (95\% CI)

$\mathbf{0}$

$\mathbf{0}$

Heterogeneity: not applicable

Test for overall effect: not applicable

Total (95\% CI)

Heterogeneity: not applicable

Test for overall effect: $Z=1.64(P=0.10)$

70

0

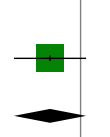

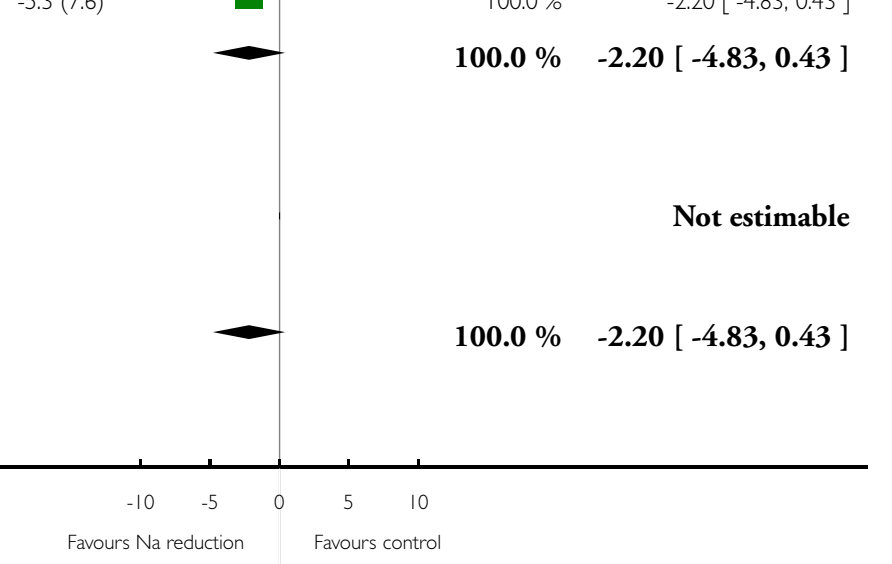

(1)

O

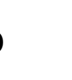




\section{Analysis 4.I. Comparison 4 Urinary sodium excretion, Outcome I Urinary sodium excretion at different times following intervention.}

Review: Advice to reduce dietary salt for prevention of cardiovascular disease

Comparison: 4 Urinary sodium excretion

Outcome: I Urinary sodium excretion at different times following intervention

Study or subgroup Low sodium Control Mean Mean

N Mean(SD) N Mean(SD) IV,Random,95\% Cl IV,Random,95\% Cl

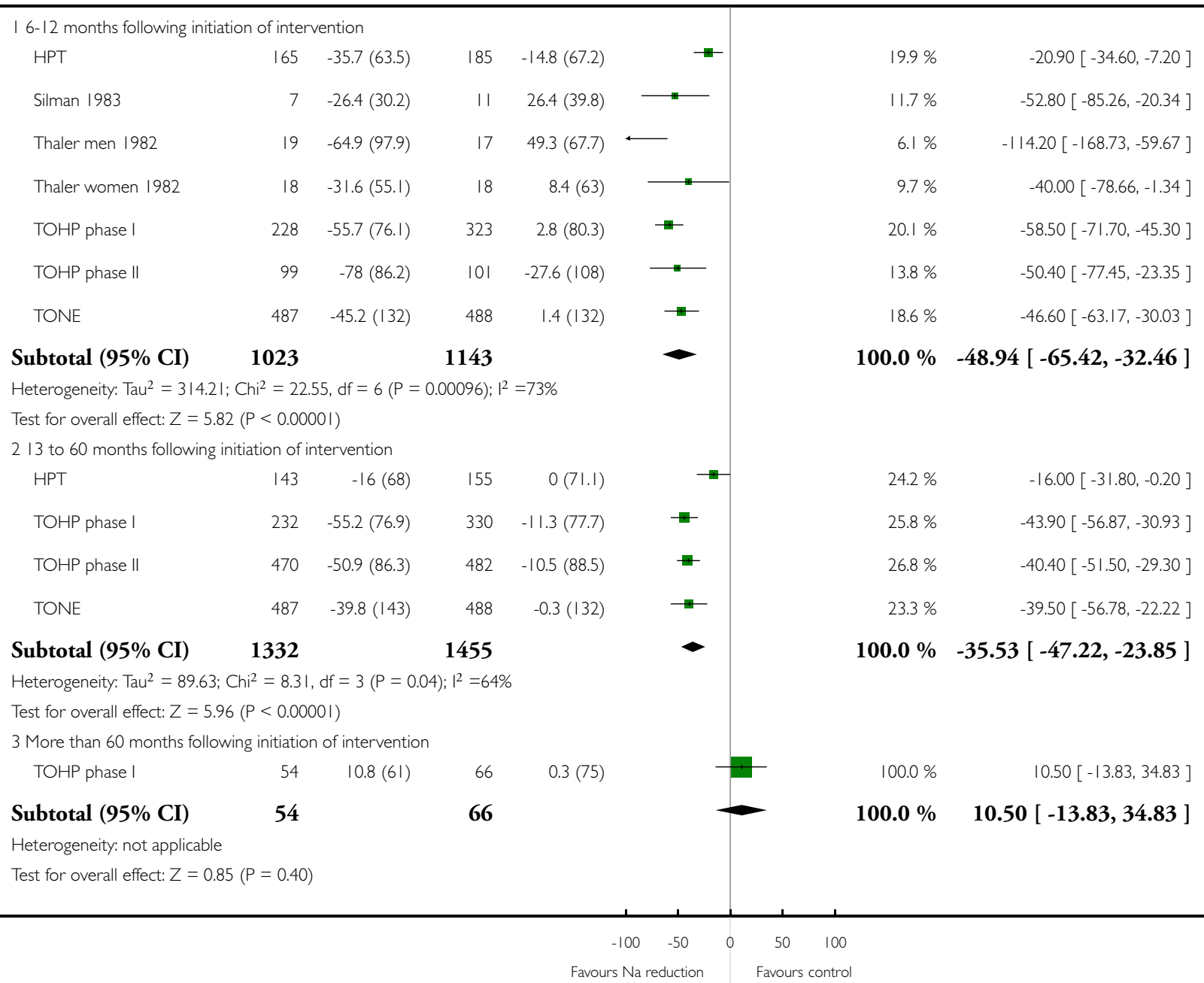




\section{Analysis 5.I. Comparison 5 Dropouts, Outcome I Comparison of dropouts at longest follow up.}

Review: Advice to reduce dietary salt for prevention of cardiovascular disease

Comparison: 5 Dropouts

Outcome: I Comparison of dropouts at longest follow up

$\begin{array}{ccc} & \mathrm{n} / \mathrm{N} & \mathrm{n} / \mathrm{N}\end{array}$

Arroll $1995 \quad 7 / 51 \quad 6 / 49$

$\begin{array}{lll}\text { HPT } & 21 / 196 & 18 / 196\end{array}$

$\begin{array}{lll}\text { Morgan } 1978 & 8 / 34 & \text { 12/33 }\end{array}$

Morgan 1987

$0 / 10$

$0 / 10$

Silman 1983

$2 / 12$

$1 / 16$

Thaler men 1982

$11 / 80$

17/84

TOHP phase I

TOHP phase II

$79 / 594$

$82 / 596$

TONE

$30 / 340$

27/34I

Total (95\% CI)

1684

1779

Total events: 195 (Low sodium), 192 (Control)

Heterogeneity: $\operatorname{Tau}^{2}=0.0 ; \mathrm{Chi}^{2}=6.89, \mathrm{df}=8(\mathrm{P}=0.55) ; \mathrm{I}^{2}=0.0 \%$

Test for overall effect: $Z=0.39(P=0.69)$

\begin{tabular}{|c|c|c|}
\hline $\begin{array}{r}\text { Risk Ratio } \\
\text { M- } \\
\text { H,Random,95\% } \\
\text { Cl }\end{array}$ & Weight & $\begin{array}{c}\text { Risk Ratio } \\
\text { M- } \\
\text { H,Random,95\% } \\
\text { Cl } \\
\end{array}$ \\
\hline & $5.6 \%$ & I.85 [0.84, 4.07 ] \\
\hline & $3.4 \%$ & $1.12[0.41,3.10]$ \\
\hline & $9.8 \%$ & $1.17[0.64,2.12]$ \\
\hline & $6.1 \%$ & $0.65[0.30,1.38]$ \\
\hline & & Not estimable \\
\hline & $0.7 \%$ & $2.67[0.27,26.09]$ \\
\hline & $7.2 \%$ & $0.68[0.34,1.36]$ \\
\hline$\square$ & $10.9 \%$ & I.33 [0.76, 2.35$]$ \\
\hline & $42.3 \%$ & $0.97[0.73,1.29]$ \\
\hline & $14.1 \%$ & $1.11[0.68,1.83]$ \\
\hline
\end{tabular}

$100.0 \%$

\section{ADDITIONAL TABLES}

Table 1. Data - total deaths and cardiovascular events (including cardiovascular deaths)

\begin{tabular}{lllll}
\hline Trial & Deaths, $\mathbf{C}$ & Deaths, LS & CV events, C & CV events, LS \\
\hline TOHP phase I & 1 (pancreatic cancer) & 0 & \\
\hline TOHP phase II & 2 (causes not specified) & 3 (causes not specified) & \\
\hline HPT & 1 (no cause specified) & 1 (no cause specified) & $\begin{array}{l}\text { 'no differences among the } \\
\text { treatment groups in gross } \\
\text { morbidity, as indicated by } \\
\text { periods of hospitalization, }\end{array}$ \\
\hline
\end{tabular}


Table 1. Data - total deaths and cardiovascular events (including cardiovascular deaths) (Continued)

or in deaths'

\begin{tabular}{|c|c|c|c|c|}
\hline Morgan 1978 & $\begin{array}{l}5 \text { (causes of death: } 1 \text { arthri- } \\
\text { tis, } 1 \text { congestive cardiac } \\
\text { failure, } 1 \text { cerebrovascu- } \\
\text { lar accident, } 1 \text { pulmonary } \\
\text { oedema and } 1 \text { unknown) }\end{array}$ & $\begin{array}{l}4 \text { (causes of death: } 1 \text { cere- } \\
\text { brovascular accident bron- } \\
\text { chospasm, } 1 \text { myocardial } \\
\text { infarction, } 1 \text { congestive } \\
\text { cardiac failure, } 1 \text { cardiores- } \\
\text { piratory failure) }\end{array}$ & $\begin{array}{l}\text { During first } 2 \text { years of } \\
\text { study } 3 \text { were treated for } \\
\text { congestive cardiac failure } \\
\text { and } 0 \text { died of } \mathrm{CV} \text { causes, } 2 \\
\text { died from CV causes dur- } \\
\text { ing the next } 3 \text { years }\end{array}$ & $\begin{array}{l}\text { During the first } 2 \text { years } \\
\text { of study } 2 \text { were treated } \\
\text { for congestive cardiac fail- } \\
\text { ure and } 1 \text { person died (of } \\
\text { CVA bronchiospasm), } 3 \\
\text { died from CV causes dur- } \\
\text { ing the next } 3 \text { years }\end{array}$ \\
\hline TONE & & & $\begin{array}{l}46 \text { people ( } 2 \text { stroke, } 7 \text { TIA, } \\
4 \text { MI, } 17 \text { angina, } 1 \text { con- } \\
\text { gestive heart failure, } 3 \text { ar- } \\
\text { rhythmia and } 19 \text { other car- } \\
\text { diovascular (further } 21 \mathrm{CV} \\
\text { events (no. of people un- } \\
\text { clear) in the weight loss } \\
\text { only group)) }\end{array}$ & $\begin{array}{l}36 \text { people ( } 1 \text { stroke, } 7 \text { TIA, } \\
2 \text { MI, } 9 \text { angina, } 2 \text { con- } \\
\text { gestive heart failure, } 6 \text { ar- } \\
\text { rhythmia and } 12 \text { other car- } \\
\text { diovascular (further } 23 \mathrm{CV} \\
\text { events (no. of people un- } \\
\text { clear) in the combined low } \\
\text { sodium and weight loss } \\
\text { group)) }\end{array}$ \\
\hline
\end{tabular}

(1 case of ischaemic heart disease in the dropouts, but not clear from controls or low salt, or whether fatal)

\begin{tabular}{l|l|lll} 
Total & 9 & 8 & 62 & 50
\end{tabular}

Table 2. Data - BP \& urinary sodium ('mean (sd)' for control / 'mean (sd)' for low salt)

\begin{tabular}{|c|c|c|c|c|c|c|c|c|c|}
\hline $\begin{array}{l}\text { Trial } \\
\text { name }\end{array}$ & $\begin{array}{l}\text { initial } \\
\mathrm{SBP}, \\
\mathrm{mmHg}\end{array}$ & $\begin{array}{l}\text { SBP ch, 6- } \\
12 \mathrm{mo}\end{array}$ & $\begin{array}{l}\text { SBP ch, } \\
13-60 \text { mo }\end{array}$ & $\begin{array}{l}\text { ini- } \\
\text { tial DBP, } \\
\text { mmHg }\end{array}$ & $\begin{array}{l}\text { DBP ch, } \\
6-12 \mathrm{mo}\end{array}$ & $\begin{array}{l}\text { DBP ch, } \\
13-60 \mathrm{mo}\end{array}$ & $\begin{array}{l}\text { initial uri- } \\
\text { nary } \mathrm{Na}\end{array}$ & $\begin{array}{l}\mathrm{Na} \text { ch, 6- } \\
12 \mathrm{mo}\end{array}$ & $\begin{array}{l}\text { Na ch, 13- } \\
60 \mathrm{mo}\end{array}$ \\
\hline HPT & $\begin{array}{l}123.9 \\
124.0\end{array}$ & $\begin{array}{l}6 \text { months:- } \\
2.1 \text { (8.3) / } \\
-3.8 \text { (7.9) } \\
\text { (adjusted) }\end{array}$ & $\begin{array}{l}36 \\
\text { months: - } \\
2.9 \text { (9.3) / } \\
-2.8 \quad(9.2) \\
\text { (adjusted) }\end{array}$ & $83.0 / 82.6$ & $\begin{array}{l}6 \text { months: } \\
-3.0(6.9) / \\
-3.4 \quad(6.6) \\
\text { (adjusted) }\end{array}$ & $\begin{array}{l}36 \\
\text { months: - } \\
3.0(6.7) / \\
-2.8 \quad(6.6) \\
\text { (adjusted) }\end{array}$ & $\begin{array}{l}164.9 \quad / \\
162.6 \text { (cor- } \\
\text { rected } \\
\text { from } 8 \\
\text { hour } \\
\text { overnight } \\
\text { urine sam- } \\
\text { ples) }\end{array}$ & $\begin{array}{l}6 \text { months: } \\
-14.8 \quad(67 . \\
2) \quad / \quad-35.7 \\
(63.5) \\
\text { (corrected } \\
\text { from } 8 \\
\text { hour } \\
\text { overnight } \\
\text { urine sam- } \\
\text { ples) }\end{array}$ & $\begin{array}{l}36 \\
\text { months: } 0 . \\
0(71.1) / \\
-16.0 \quad(68 . \\
0) \\
\text { (corrected } \\
\text { from } 8 \\
\text { hour } \\
\text { overnight } \\
\text { urine sam- } \\
\text { ples) }\end{array}$ \\
\hline $\begin{array}{l}\text { TOHP } \\
\text { phase I }\end{array}$ & $\begin{array}{l}125.1 \\
(8.1) / 124 . \\
8(8.5)\end{array}$ & $\begin{array}{l}12 \\
\text { months: } \\
-3.9(7.4) /\end{array}$ & $\begin{array}{l}18 \\
\text { months: - } \\
3.16(8.1) /\end{array}$ & $\begin{array}{l}83.9(2.8) / \\
83.7(2.7)\end{array}$ & $\begin{array}{l}12 \\
\text { months: } \\
-3.4(5.7) /\end{array}$ & $\begin{array}{l}18 \\
\text { months: - } \\
3.3(5.7) /-\end{array}$ & $\begin{array}{l}156.4(60 . \\
5) / \quad 154.6 \\
(59.9)\end{array}$ & $\begin{array}{l}6 \text { months: } \\
+2.8 \quad(80 \text {. }\end{array}$ & $\begin{array}{l}18 \\
\text { months: }\end{array}$ \\
\hline
\end{tabular}


Table 2. Data - BP \& urinary sodium ('mean (sd)' for control / 'mean (sd)' for low salt) (Continued)

\begin{tabular}{|c|c|c|c|c|c|c|c|c|c|}
\hline & & $-5.8(7.5)$ & $-4.9(7.8)$ & & $-4.4(5.4)$ & $4.1(5.7)$ & & $\begin{array}{l}\text { 3) / }-55.7 \\
(76.1)\end{array}$ & $\begin{array}{l}-11.3 \quad(77 . \\
7) /-55.2 \\
(76.9)\end{array}$ \\
\hline $\begin{array}{l}\text { TOHP } \\
\text { phase II }\end{array}$ & $\begin{array}{l}127.3 \\
(6.4) / 127 . \\
7(6.6)\end{array}$ & $\begin{array}{l}6 \text { months:- } \\
2.2(8.1) /- \\
5.1(8.6)\end{array}$ & $\begin{array}{l}36 \\
\text { months: } \\
+0.3(8.9) / \\
-0.7(9.2)\end{array}$ & $\begin{array}{l}85.8(1.9) / \\
86.1(1.9)\end{array}$ & $\begin{array}{l}6 \text { months:- } \\
2.8(6.1) /- \\
4.4(6.7)\end{array}$ & $\begin{array}{l}36 \\
\text { months: - } \\
2.4(7.1) /- \\
2.9(6.8)\end{array}$ & $\begin{array}{l}188.0(80 . \\
9) \quad / 186.1 \\
(80.7)\end{array}$ & $\begin{array}{l}6 \text { months: } \\
- \\
27.6 \text { (108. } \\
0) / \quad-78.0 \\
(86.2)\end{array}$ & $\begin{array}{l}36 \\
\text { months: } \\
-10.5 \text { (88. } \\
5) /-50.9 \\
(86.3)\end{array}$ \\
\hline $\begin{array}{l}\text { Morgan } \\
1978\end{array}$ & $\begin{array}{l}165 \text { (16.7) } \\
/ 160 \quad(22 . \\
3)\end{array}$ & $\begin{array}{l}12 \\
\text { months: } \\
-3(22.3) /- \\
3(22.3)\end{array}$ & $\begin{array}{l}24 \\
\text { months: } \\
-4(22.3) \text { /- } \\
5.5(22.3)\end{array}$ & $\begin{array}{l}97(8.6) / \\
97(8.7)\end{array}$ & $\begin{array}{l}12 \\
\text { months: } \\
+1(11.1) / \\
-3(11.1)\end{array}$ & $\begin{array}{l}24 \\
\text { months: } \\
+2(11.1) / \\
-5(11.1)\end{array}$ & $\begin{array}{l}191(35) / \\
195(55.0)\end{array}$ & Not given & $\begin{array}{l}24 \\
\text { months: - } \\
11 /-38\end{array}$ \\
\hline $\begin{array}{l}\text { Costa } \\
1981\end{array}$ & $\begin{array}{l}143.4(13) \\
/ 143.3 \\
(15)\end{array}$ & $\begin{array}{l}12 \\
\text { months: } \\
4.3(18.8) \\
\text { /-14.0 (18. } \\
\text { 5) (sd im- } \\
\text { puted) }\end{array}$ & & $\begin{array}{l}84.1 \text { (7) / } \\
84.2(9)\end{array}$ & $\begin{array}{l}12 \\
\text { months: - } \\
0.2 \quad(32.6) \\
1-6.1 \quad(31 . \\
7) \quad \text { (calcu- } \\
\text { lated sd) }\end{array}$ & & Not given & Not given & \\
\hline $\begin{array}{l}\text { Thaler } \\
1982 \text {, in- } \\
\text { dex men }\end{array}$ & $\begin{array}{l}139(12) / \\
137(14)\end{array}$ & $\begin{array}{l}12 \\
\text { months: } \\
+3.4 \quad(17 \\
4) /-5.0 \\
(8.3) \text { (lev- } \\
\text { els of med- } \\
\text { ication al- } \\
\text { tered in } \\
\text { some par- } \\
\text { ticipants } \\
\text { through } \\
\text { trial) }\end{array}$ & & $\begin{array}{l}90(12) / 86 \\
(9)\end{array}$ & $\begin{array}{l}12 \\
\text { months: } \\
+0.8 \text { (9.2) } \\
\text { I+0.6 (9.2) } \\
\text { (lev- } \\
\text { els of med- } \\
\text { ication al- } \\
\text { tered in } \\
\text { some par- } \\
\text { ticipants } \\
\text { through } \\
\text { trial) }\end{array}$ & & $\begin{array}{l}159.5(72 . \\
5) / 178.1 \\
(76.5)\end{array}$ & $\begin{array}{l}12 \\
\text { months: } \\
+49.3 \text { (67. } \\
7) /-64.9 \\
(97.9)\end{array}$ & \\
\hline $\begin{array}{l}\text { Thaler } \\
1982 \text {, in- } \\
\text { dex } \\
\text { women }\end{array}$ & $\begin{array}{l}148(25) / \\
145(18)\end{array}$ & $\begin{array}{l}12 \\
\text { months: } \\
+1.1 \quad(14 . \\
4) \quad /-11.1 \\
(24.2) \text { (lev- } \\
\text { els of med- } \\
\text { ication al- } \\
\text { tered in } \\
\text { some par- } \\
\text { ticipants } \\
\text { through } \\
\text { trial) }\end{array}$ & & $\begin{array}{l}83(12) / 86 \\
(11)\end{array}$ & $\begin{array}{l}12 \\
\text { months: } \\
+2.8(8.5) / \\
-6.8(11.9) \\
\text { (lev- } \\
\text { els of med- } \\
\text { ication al- } \\
\text { tered in } \\
\text { some par- } \\
\text { ticipants } \\
\text { through } \\
\text { trial) }\end{array}$ & & $\begin{array}{l}120.1(41 . \\
5) \quad / 118.0 \\
(39.9)\end{array}$ & $\begin{array}{l}12 \\
\text { months: } \\
+8.4 \quad(63 . \\
0) / \quad-31.6 \\
(55.1)\end{array}$ & \\
\hline
\end{tabular}


Table 2. Data - BP \& urinary sodium ('mean (sd)' for control / 'mean (sd)' for low salt) (Continued)

\begin{tabular}{|c|c|c|c|c|c|c|c|}
\hline $\begin{array}{l}\text { Silman } \\
1983\end{array}$ & $\begin{array}{l}160.5 \\
165.3\end{array}$ & $\begin{array}{l}12 \\
\text { months: } \\
-20.0 \quad(24 . \\
0) \quad /-28.7 \\
(26.6)\end{array}$ & $98.3 / 98.8$ & $\begin{array}{l}12 \\
\text { months: - } \\
11 . \\
4(10.5) / \\
-17.7 \quad(11 . \\
4)\end{array}$ & $\begin{array}{l}146.5 \\
150.8\end{array}$ & $\begin{array}{l}12 \\
\text { months: } \\
26.4 \quad(39 . \\
8) / \quad-26.4 \\
(30.2)\end{array}$ & \\
\hline Alli 1992 & $\begin{array}{l}148.3(10 . \\
6) / 150.8 \\
(8.7)\end{array}$ & $\begin{array}{l}12 \\
\text { months: } \\
-0.3(16.4) \\
\text { /-6.6 (13. } \\
6) \text { (sd im- } \\
\text { puted) }\end{array}$ & $\begin{array}{l}97.2(3.8) / \\
97.0(3.1)\end{array}$ & $\begin{array}{l}12 \\
\text { months: - } \\
2.7(16.6) \\
\text { / -6.4 (18. } \\
5) \text { (sd cal- } \\
\text { culated) }\end{array}$ & $\begin{array}{l}177.3(61 . \\
7) \quad / 177.3 \\
(61.0)\end{array}$ & $\begin{array}{l}12 \\
\text { months: } \\
-4.2 /+8.6 \\
\text { (data mea- } \\
\text { sured off } \\
\text { graph) }\end{array}$ & \\
\hline $\begin{array}{l}\text { Morgan } \\
1987\end{array}$ & $\begin{array}{l}143(15.8) \\
/ 143 \quad(15 . \\
8)\end{array}$ & $\begin{array}{l}9 \text { months: } \\
+35(25.7) \\
/+12 \text { (21. } \\
5) \text { (sd im- } \\
\text { puted, lev- } \\
\text { els of med- } \\
\text { ication al- } \\
\text { tered in } \\
\text { some par- } \\
\text { ticipants } \\
\text { through } \\
\text { trial) }\end{array}$ & $\begin{array}{l}81(6.3) / \\
83(6.3)\end{array}$ & $\begin{array}{l}9 \text { months: } \\
+17 \text { (28.7) } \\
\text { I+7 (22.2) } \\
\text { (sd calcu- } \\
\text { lated, lev- } \\
\text { els of med- } \\
\text { ication al- } \\
\text { tered in } \\
\text { some par- } \\
\text { ticipants } \\
\text { through } \\
\text { trial) }\end{array}$ & $\begin{array}{l}163(50.6) \\
/ 168 \quad(37 . \\
9)\end{array}$ & $-8 /-93$ & \\
\hline $\begin{array}{l}\text { Arroll } \\
1995\end{array}$ & $\begin{array}{l}145.3(15 . \\
7) \quad / 145.4 \\
(15.9)\end{array}$ & $\begin{array}{l}6 \text { months: } \\
-6.2(21.0) \\
\text { /-9.1 (21. } \\
7) \text { (sd im- } \\
\text { puted, lev- } \\
\text { els of med- } \\
\text { ication al- } \\
\text { tered in } \\
\text { some par- } \\
\text { ticipants } \\
\text { through } \\
\text { trial) }\end{array}$ & $\begin{array}{l}94.0(9.8) / \\
86.4(9.9)\end{array}$ & $\begin{array}{l}6 \text { months: } \\
-4.8 \text { (36.1) } \\
\text { / -1.7 (34. } \\
9 \text { ) (sd cal- } \\
\text { cu- } \\
\text { lated, lev- } \\
\text { els of med- } \\
\text { ication al- } \\
\text { tered in } \\
\text { some par- } \\
\text { ticipants } \\
\text { through } \\
\text { trial) }\end{array}$ & Not given & Not given & \\
\hline TONE & $\begin{array}{l}128(9) / \\
129(9)\end{array}$ & Not given & $\begin{array}{l}71(7) / 72 \\
(7)\end{array}$ & Not given & $\begin{array}{l}146.2 \\
145.3\end{array}$ & $\begin{array}{l}9 \text { months: } \\
+1 . \\
4(132) /- \\
45.2(132) \\
\text { (data in- } \\
\text { clude those } \\
\text { in weight }\end{array}$ & $\begin{array}{l}30 \\
\text { months:-0. } \\
3 \text { (132) /- } \\
39.8 \text { (143) } \\
\text { (data in- } \\
\text { clude those } \\
\text { in weight }\end{array}$ \\
\hline
\end{tabular}


Table 2. Data - BP \& urinary sodium ('mean (sd)' for control / 'mean (sd)' for low salt) (Continued)

loss group loss group with con- with control, trol, and weight and weight loss plus loss plus sodium re- sodium reduction duction with inter- with intervention) vention)

Table 3. Meta-analysis, sugrouping and sensitivity analysis results

\begin{tabular}{|c|c|c|c|c|c|c|c|c|}
\hline Outcome & Time & & $\begin{array}{l}\text { Type of anal- } \\
\text { ysis }\end{array}$ & Description & $\begin{array}{l}\text { Number of } \\
\text { studies }\end{array}$ & WMD & $95 \% \mathrm{CI}$ & $\begin{array}{l}\text { p for hetero- } \\
\text { geneity }\end{array}$ \\
\hline $\begin{array}{l}\text { Systolic } \\
\text { blood pressure } \\
(\mathrm{mmHg})\end{array}$ & $\begin{array}{l}6 \text { to } \\
\text { months }\end{array}$ & 12 & $\begin{array}{l}\text { Overall meta- } \\
\text { analysis }\end{array}$ & & 7 & -2.5 & -3.8 to -1.2 & 0.08 \\
\hline $\begin{array}{l}\text { Systolic } \\
\text { blood pressure } \\
(\mathrm{mmHg})\end{array}$ & $\begin{array}{l}6 \text { to } \\
\text { months }\end{array}$ & 12 & $\begin{array}{l}\text { Sensitivity } \\
\text { analysis }\end{array}$ & $\begin{array}{l}\text { Drop imputed } \\
\text { standard devi- } \\
\text { ations }\end{array}$ & 5 & -2.3 & -3.0 to -1.7 & 0.57 \\
\hline $\begin{array}{l}\text { Systolic } \\
\text { blood pressure } \\
(\mathrm{mmHg})\end{array}$ & $\begin{array}{l}6 \text { to } \\
\text { months }\end{array}$ & 12 & $\begin{array}{l}\text { Sensitivity } \\
\text { analysis }\end{array}$ & $\begin{array}{l}\text { Small- } \\
\text { est calculated } \\
\text { standard devi- } \\
\text { ations }\end{array}$ & 7 & -3.1 & -4.8 to -1.3 & $<0.01$ \\
\hline $\begin{array}{l}\text { Systolic } \\
\text { blood pressure } \\
(\mathrm{mmHg})\end{array}$ & $\begin{array}{l}6 \text { to } \\
\text { months }\end{array}$ & 12 & $\begin{array}{l}\text { Sensitivity } \\
\text { analysis }\end{array}$ & $\begin{array}{l}\text { Allocation } \\
\text { concealment }\end{array}$ & 3 & -2.3 & -3.1 to -1.6 & 0.31 \\
\hline $\begin{array}{l}\text { Systolic } \\
\text { blood pressure } \\
(\mathrm{mmHg})\end{array}$ & $\begin{array}{l}6 \text { to } \\
\text { months }\end{array}$ & 12 & $\begin{array}{l}\text { Sensitivity } \\
\text { analysis }\end{array}$ & $\begin{array}{l}\text { Including } \\
\text { weight arms }\end{array}$ & 7 & -1.6 & -3.0 to -0.2 & $<0.01$ \\
\hline $\begin{array}{l}\text { Systolic } \\
\text { blood pressure } \\
(\mathrm{mmHg})\end{array}$ & $\begin{array}{l}6 \text { to } \\
\text { months }\end{array}$ & 12 & Subgrouping & $\begin{array}{l}\text { Normoten- } \\
\text { sives }\end{array}$ & 3 & -2.3 & -3.1 to -1.6 & 0.31 \\
\hline $\begin{array}{l}\text { Systolic } \\
\text { blood pressure } \\
(\mathrm{mmHg})\end{array}$ & $\begin{array}{l}6 \text { to } \\
\text { months }\end{array}$ & 12 & Subgrouping & $\begin{array}{l}\text { Untreated hy- } \\
\text { pertensives }\end{array}$ & 4 & -8.0 & -15.8 to -0.2 & 0.15 \\
\hline
\end{tabular}


Table 3. Meta-analysis, sugrouping and sensitivity analysis results (Continued)

\begin{tabular}{|c|c|c|c|c|c|c|c|}
\hline $\begin{array}{l}\text { Systolic } \\
\text { blood pressure } \\
(\mathrm{mmHg})\end{array}$ & $\begin{array}{l}13 \text { to } 60 \\
\text { months }\end{array}$ & $\begin{array}{l}\text { Overall meta- } \\
\text { analysis }\end{array}$ & & 4 & -1.1 & -1.8 to -0.4 & 0.46 \\
\hline $\begin{array}{l}\text { Systolic } \\
\text { blood pressure } \\
(\mathrm{mmHg})\end{array}$ & $\begin{array}{l}13 \text { to } 60 \\
\text { months }\end{array}$ & $\begin{array}{l}\text { Sensitivity } \\
\text { analysis }\end{array}$ & $\begin{array}{l}\text { Allocation } \\
\text { concealment }\end{array}$ & 3 & -1.1 & -1.9 to -0.3 & 0.28 \\
\hline $\begin{array}{l}\text { Systolic } \\
\text { blood pressure } \\
(\mathrm{mmHg})\end{array}$ & $\begin{array}{l}13 \text { to } 60 \\
\text { months }\end{array}$ & $\begin{array}{l}\text { Sensitivity } \\
\text { analysis }\end{array}$ & $\begin{array}{l}\text { Including } \\
\text { weight arms }\end{array}$ & 4 & -0.5 & -1.4 to 0.4 & 0.10 \\
\hline $\begin{array}{l}\text { Systolic } \\
\text { blood pressure } \\
(\mathrm{mmHg})\end{array}$ & $\begin{array}{l}13 \text { to } 60 \\
\text { months }\end{array}$ & Subgrouping & $\begin{array}{l}\text { Normoten- } \\
\text { sives }\end{array}$ & 3 & -1.1 & -1.9 to -0.3 & 0.28 \\
\hline $\begin{array}{l}\text { Systolic } \\
\text { blood pressure } \\
(\mathrm{mmHg})\end{array}$ & $\begin{array}{l}13 \text { to } 60 \\
\text { months }\end{array}$ & Subgrouping & $\begin{array}{l}\text { Untreated hy- } \\
\text { pertensives }\end{array}$ & 1 & -1.5 & -12.6 to 9.6 & - \\
\hline $\begin{array}{l}\text { Systolic } \\
\text { blood pressure } \\
(\mathrm{mmHg})\end{array}$ & $>60$ months & $\begin{array}{l}\text { Overall meta- } \\
\text { analysis }\end{array}$ & & 1 & -3.8 & -7.9 to 0.3 & - \\
\hline $\begin{array}{l}\text { Diastolic } \\
\text { blood pressure } \\
(\mathrm{mmHg})\end{array}$ & $\begin{array}{l}6 \text { to } \\
\text { months }\end{array}$ & $\begin{array}{l}\text { Overall meta- } \\
\text { analysis }\end{array}$ & & 5 & -1.2 & -1.8 to -0.6 & 0.31 \\
\hline $\begin{array}{l}\text { Diastolic } \\
\text { blood pressure } \\
(\mathrm{mmHg})\end{array}$ & $\begin{array}{l}6 \text { to } \\
\text { months }\end{array}$ & $\begin{array}{l}\text { Sensitivity } \\
\text { analysis }\end{array}$ & $\begin{array}{l}\text { Drop imputed } \\
\text { standard devi- } \\
\text { ations }\end{array}$ & $\begin{array}{l}\text { imputed stan- } \\
\text { dar deviations } \\
\text { no longer used } \\
\text { for diastolic } \\
\text { blood pressure }\end{array}$ & & & \\
\hline $\begin{array}{l}\text { Diastolic } \\
\text { blood pressure } \\
(\mathrm{mmHg})\end{array}$ & $\begin{array}{l}6 \text { to } \\
\text { months }\end{array}$ & $\begin{array}{l}\text { Sensitivity } \\
\text { analysis }\end{array}$ & $\begin{array}{l}\text { Small- } \\
\text { est calculated } \\
\text { standard devi- } \\
\text { ations }\end{array}$ & $\begin{array}{l}\text { imputed stan- } \\
\text { dar deviations } \\
\text { no longer used } \\
\text { for diastolic } \\
\text { blood pressure }\end{array}$ & & & \\
\hline $\begin{array}{l}\text { Diastolic } \\
\text { blood pressure } \\
(\mathrm{mmHg})\end{array}$ & $\begin{array}{l}6 \text { to } \\
\text { months }\end{array}$ & $\begin{array}{l}\text { Sensitivity } \\
\text { analysis }\end{array}$ & $\begin{array}{l}\text { Allocation } \\
\text { concealment }\end{array}$ & 3 & -1.2 & -1.8 to -0.6 & 0.28 \\
\hline $\begin{array}{l}\text { Diastolic } \\
\text { blood pressure } \\
(\mathrm{mmHg})\end{array}$ & $\begin{array}{l}6 \text { to } 12 \\
\text { months }\end{array}$ & $\begin{array}{l}\text { Sensitivity } \\
\text { analysis }\end{array}$ & $\begin{array}{l}\text { Including } \\
\text { weight arms }\end{array}$ & 7 & -0.7 & -1.5 to 0.1 & 0.05 \\
\hline
\end{tabular}


Table 3. Meta-analysis, sugrouping and sensitivity analysis results (Continued)

\begin{tabular}{|c|c|c|c|c|c|c|c|c|}
\hline $\begin{array}{l}\text { Diastolic } \\
\text { blood pressure } \\
(\mathrm{mmHg})\end{array}$ & $\begin{array}{l}6 \text { to } \\
\text { months }\end{array}$ & 12 & Subgrouping & $\begin{array}{l}\text { Normoten- } \\
\text { sives }\end{array}$ & 3 & -1.2 & -1.8 to -0.6 & 0.28 \\
\hline $\begin{array}{l}\text { Diastolic } \\
\text { blood pressure } \\
(\mathrm{mmHg})\end{array}$ & $\begin{array}{l}6 \text { to } \\
\text { months }\end{array}$ & 12 & Subgrouping & $\begin{array}{l}\text { Untreated hy- } \\
\text { pertensives }\end{array}$ & 2 & -4.7 & -9.3 to 0.0 & 0.67 \\
\hline $\begin{array}{l}\text { Diastolic } \\
\text { blood pressure } \\
(\mathrm{mmHg})\end{array}$ & $\begin{array}{l}13 \text { to } \\
\text { months }\end{array}$ & 60 & $\begin{array}{l}\text { Overall meta- } \\
\text { analysis }\end{array}$ & & 4 & -0.6 & -1.5 to 0.3 & 0.08 \\
\hline $\begin{array}{l}\text { Diastolic } \\
\text { blood pressure } \\
(\mathrm{mmHg})\end{array}$ & $\begin{array}{l}13 \text { to } \\
\text { months }\end{array}$ & 60 & $\begin{array}{l}\text { Sensitivity } \\
\text { analysis }\end{array}$ & $\begin{array}{l}\text { Allocation } \\
\text { concealment }\end{array}$ & 3 & -0.5 & -1.1 to 0.0 & 0.48 \\
\hline $\begin{array}{l}\text { Diastolic } \\
\text { blood pressure } \\
(\mathrm{mmHg})\end{array}$ & $\begin{array}{l}13 \text { to } \\
\text { months }\end{array}$ & 60 & $\begin{array}{l}\text { Sensitivity } \\
\text { analysis }\end{array}$ & $\begin{array}{l}\text { Including } \\
\text { weight arms }\end{array}$ & 4 & -0.3 & -1.0 to 0.4 & 0.06 \\
\hline $\begin{array}{l}\text { Diastolic } \\
\text { blood pressure } \\
(\mathrm{mmHg})\end{array}$ & $\begin{array}{l}13 \text { to } \\
\text { months }\end{array}$ & 60 & Subgrouping & $\begin{array}{l}\text { Normoten- } \\
\text { sives }\end{array}$ & 3 & -0.5 & -1.1 to 0.0 & 0.48 \\
\hline $\begin{array}{l}\text { Diastolic } \\
\text { blood pressure } \\
(\mathrm{mmHg})\end{array}$ & $\begin{array}{l}13 \text { to } \\
\text { months }\end{array}$ & 60 & Subgrouping & $\begin{array}{l}\text { Untreated hy- } \\
\text { pertensives }\end{array}$ & 1 & -7.0 & -12.5 to -1.5 & - \\
\hline $\begin{array}{l}\text { Diastolic } \\
\text { blood pressure } \\
(\mathrm{mmHg})\end{array}$ & $>60$ month & & $\begin{array}{l}\text { Overall meta- } \\
\text { analysis }\end{array}$ & & 1 & -2.2 & -4.8 to 0.4 & - \\
\hline $\begin{array}{l}\text { Sodium ex- } \\
\text { cretion (mmol } \\
\mathrm{Na} / 24 \text { hours) }\end{array}$ & $\begin{array}{l}6 \text { to } \\
\text { months }\end{array}$ & 12 & $\begin{array}{l}\text { Overall meta- } \\
\text { analysis }\end{array}$ & & 6 & -48.9 & -65.4 to -32.5 & $<0.01$ \\
\hline $\begin{array}{l}\text { Sodium ex- } \\
\text { cretion (mmol } \\
\mathrm{Na} / 24 \text { hours) }\end{array}$ & $\begin{array}{l}6 \text { to } \\
\text { months }\end{array}$ & 12 & $\begin{array}{l}\text { Sensitivity } \\
\text { analysis }\end{array}$ & $\begin{array}{l}\text { Allocation } \\
\text { concealment }\end{array}$ & 4 & -43.6 & -62.6 to -24.6 & $<0.01$ \\
\hline $\begin{array}{l}\text { Sodium ex- } \\
\text { cretion (mmol } \\
\mathrm{Na} / 24 \text { hours) }\end{array}$ & $\begin{array}{l}6 \text { to } \\
\text { months }\end{array}$ & 12 & $\begin{array}{l}\text { Sensitivity } \\
\text { analysis }\end{array}$ & $\begin{array}{l}\text { Including } \\
\text { weight arms }\end{array}$ & 6 & -44.3 & -58.4 to -30.2 & $<0.01$ \\
\hline $\begin{array}{l}\text { Sodium ex- } \\
\text { cretion (mmol } \\
\mathrm{Na} / 24 \text { hours) }\end{array}$ & $\begin{array}{l}13 \text { to } \\
\text { months }\end{array}$ & & $\begin{array}{l}\text { Overall meta- } \\
\text { analysis }\end{array}$ & & 4 & -35.5 & -47.2 to -23.9 & 0.04 \\
\hline
\end{tabular}


Table 3. Meta-analysis, sugrouping and sensitivity analysis results (Continued)

\begin{tabular}{l|l|l|l|l|l|l|l|l|l|}
\hline $\begin{array}{l}\text { Sodium ex- } \\
\text { cretion (mmol } \\
\mathrm{Na} / 24 \text { hours) }\end{array}$ & $\begin{array}{l}13 \text { to } \\
\text { months }\end{array}$ & 60 & $\begin{array}{l}\text { Sensitivity } \\
\text { analysis }\end{array}$ & $\begin{array}{l}\text { Allocation } \\
\text { concealment }\end{array}$ & 4 & -35.5 & -47.2 to -23.9 & 0.04 \\
\hline $\begin{array}{l}\text { Sodium ex- } \\
\text { cretion (mmol } \\
\mathrm{Na} / 24 \text { hours) }\end{array}$ & $\begin{array}{l}13 \text { to } \\
\text { months }\end{array}$ & 60 & $\begin{array}{l}\text { Sensitivity } \\
\text { analysis }\end{array}$ & $\begin{array}{l}\text { Including } \\
\text { weight arms }\end{array}$ & 4 & -33.3 & -42.0 to -24.6 & 0.05 \\
\hline $\begin{array}{l}\text { Sodium ex- } \\
\text { cretion (mmol } \\
\mathrm{Na} / 24 \text { hours) }\end{array}$ & $>60$ months & $\begin{array}{l}\text { Overall meta- } \\
\text { analysis }\end{array}$ & 1 & 10.5 & -13.8 to 34.8 & - \\
\hline $\begin{array}{l}\text { Lropouts } \\
\text { Latest follow }\end{array}$ & $\begin{array}{l}\text { Overall meta- } \\
\text { analysis }\end{array}$ & $\begin{array}{l}\text { Dropouts in } \\
\text { low sodium vs } \\
\text { control groups }\end{array}$ & 10 & $\begin{array}{l}\text { Relative risk }= \\
1.04\end{array}$ & 0.86 to 1.25 & 0.55 \\
\hline
\end{tabular}

Table 4. Meta-regression results, effects on SBP at 6 to 12 months

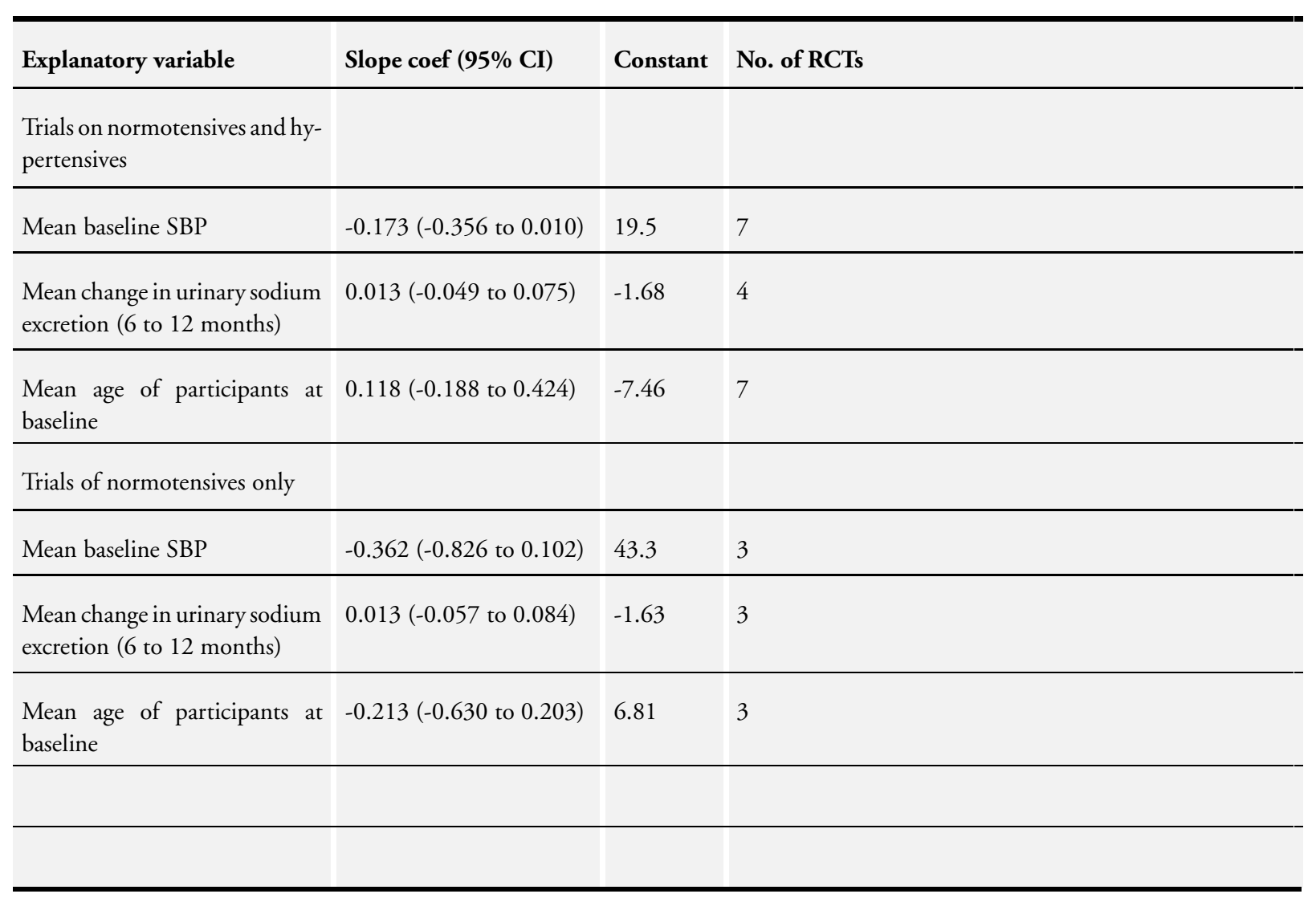


Table 5. Characteristics of systematic reviews on salt and blood pressure

\begin{tabular}{|c|c|c|c|c|c|c|c|c|c|}
\hline Review & $\begin{array}{l}\text { Inclusion } \\
\text { criteria }\end{array}$ & $\begin{array}{l}\text { RCTs } \\
\text { only? }\end{array}$ & $\begin{array}{l}\text { Normo/ } \\
\text { hyper ten- } \\
\text { sive }\end{array}$ & $\begin{array}{l}\text { Median } \\
\text { duration }\end{array}$ & $\begin{array}{l}\text { No. trials } \\
\text { (n) }\end{array}$ & $\begin{array}{l}\text { Fall in } \mathrm{Na} \\
\text { excretion }\end{array}$ & $\begin{array}{l}\text { WMD } \\
\text { SBP } \\
(95 \% \mathrm{CI})\end{array}$ & $\begin{array}{l}\text { WMD } \\
\text { DBP } \\
(95 \% C I)\end{array}$ & $\begin{array}{l}\text { Qual- } \\
\text { ity assess- } \\
\text { ment }\end{array}$ \\
\hline $\begin{array}{l}\text { Graudal } \\
1998\end{array}$ & $\begin{array}{l}\text { Popu- } \\
\text { lation: } \\
\text { mean age } \\
>15 \text { years, } \\
\text { Interven- } \\
\text { tion: low } \\
\text { sodium } \\
\text { or high } \\
\text { sodium } \\
\text { diet, } \\
\text { no con- } \\
\text { founding, } \\
\text { Outcome: } \\
\text { urinary } \\
\text { sodium } \\
\text { excretion } \\
\text { measured, } \\
\text { systolic, } \\
\text { diastolic or } \\
\text { mean BP } \\
\text { reported }\end{array}$ & $\begin{array}{l}\text { Yes, } \\
\text { random al- } \\
\text { location, } \\
\text { parallel or } \\
\text { crossover }\end{array}$ & $\begin{array}{l}\text { Nor- } \\
\text { motensive }\end{array}$ & $\begin{array}{l}8(4-1100) \\
\text { days }\end{array}$ & $56(2581)$ & $\begin{array}{l}\text { weighted } \\
\text { mean } 160\end{array}$ & $\begin{array}{l}-1.2 \quad(-0.6 \\
\text { to }-1.8)\end{array}$ & $\begin{array}{l}-0.26(+0 . \\
3 \text { to }-0.9)\end{array}$ & $\begin{array}{l}\text { QA: sub- } \\
\text { grouping } \\
\text { by } \\
\text { open/ sin- } \\
\text { gle blind or } \\
\text { double } \\
\text { blind } \\
\text { method } \\
\text { did not af- } \\
\text { fect results. } \\
\text { Notes: Sta- } \\
\text { tistical het- } \\
\text { erogeneity } \\
\text { noted }\end{array}$ \\
\hline $\begin{array}{l}\text { Graudal } \\
1998\end{array}$ & & & $\begin{array}{l}\text { Hyperten- } \\
\text { sive }\end{array}$ & $\begin{array}{l}28(4-365) \\
\text { days }\end{array}$ & $58(2161)$ & $\begin{array}{l}\text { weighted } \\
\text { mean } 118\end{array}$ & $\begin{array}{l}-3.9 \quad(-3.0 \\
\text { to }-4.8)\end{array}$ & $\begin{array}{l}-1.9(-1.3 \\
\text { to }-2.5)\end{array}$ & \\
\hline $\begin{array}{l}\text { Midgley } \\
1996\end{array}$ & $\begin{array}{l}\text { Popu- } \\
\text { lation: } \\
\text { human, } \\
\text { not on } \\
\text { antihy- } \\
\text { pertensive } \\
\text { drugs, In- } \\
\text { tervention: } \\
\text { dietary } \\
\text { sodium in- } \\
\text { tervention, } \\
\text { Outcome: } \\
\text { diastolic } \\
\text { and sys- } \\
\text { tolic BP } \\
\text { measure- } \\
\text { ment, } \\
\text { urinary } \\
\text { sodium }\end{array}$ & $\begin{array}{l}\text { Yes, ran- } \\
\text { domised } \\
\text { controlled } \\
\text { trials } \\
\text { (crossover } \\
\text { or parallel } \\
\text { design) }\end{array}$ & $\begin{array}{l}\text { Nor- } \\
\text { motensive }\end{array}$ & $\begin{array}{l}14 \\
1095) \text { days }\end{array}$ & $28(2374)$ & $\begin{array}{l}\text { weighted } \\
\text { mean } 125 \\
(95 \% \quad \text { CI } \\
95-156)\end{array}$ & $\begin{array}{l}-1.6(-2.41 \\
\text { to }-0.89)\end{array}$ & $\begin{array}{l}-0.5(-1.18 \\
\text { to } 0.11)\end{array}$ & $\begin{array}{l}\text { QA: Sig- } \\
\text { nificant } \\
\text { hetero- } \\
\text { geneity } \\
\text { seen, } \\
\text { reduced } \\
\text { but not } \\
\text { eliminated } \\
\text { when stud- } \\
\text { ies sub- } \\
\text { grouped } \\
\text { according } \\
\text { to quality } \\
\text { charac- } \\
\text { teristics. } \\
\text { Notes: } \\
\text { Evidence }\end{array}$ \\
\hline
\end{tabular}


Table 5. Characteristics of systematic reviews on salt and blood pressure (Continued)

\begin{tabular}{|c|c|c|c|c|c|c|c|c|c|}
\hline & $\begin{array}{l}\text { excretion- } \\
\text { Design: } \\
\text { English } \\
\text { language, } \\
\text { full-length } \\
\text { journal } \\
\text { articles }\end{array}$ & & & & & & & & $\begin{array}{l}\text { of publica- } \\
\text { tion bias } \\
\text { provided }\end{array}$ \\
\hline $\begin{array}{l}\text { Midgley } \\
1996\end{array}$ & & & $\begin{array}{l}\text { Hyperten- } \\
\text { sive }\end{array}$ & $\begin{array}{l}29 \quad(4 \quad- \\
730) \text { days }\end{array}$ & $28(1131)$ & $\begin{array}{l}\text { Weighted } \\
\text { mean } 95 \\
(95 \% \quad \text { CI } \\
71-119)\end{array}$ & $\begin{array}{l}-5.9(-7.77 \\
\text { to }-4.12)\end{array}$ & $\begin{array}{l}-3.8(-4.78 \\
\text { to }-2.9)\end{array}$ & \\
\hline Law 1991 & $\begin{array}{l}\text { Popula- } \\
\text { tion: not } \\
\text { on antihy- } \\
\text { pertensive } \\
\text { drugs, In- } \\
\text { tervention: } \\
\text { dietary } \\
\text { sodium } \\
\text { restriction, } \\
\text { not con- } \\
\text { founded, } \\
\text { Outcome: } \\
24 \text { hour } \\
\text { urine } \\
\text { collection, } \\
\text { systolic } \\
\text { and/or } \\
\text { diastolic } \\
\text { BP }\end{array}$ & No. & $\begin{array}{l}\text { Nor- } \\
\text { motensive }\end{array}$ & $\begin{array}{l}1.5 \text { ( } 0.7 \text { to } \\
16) \text { weeks }\end{array}$ & 15 (?) & Not stated & Not stated & Not stated & $\begin{array}{l}\text { QA: Qual- } \\
\text { ity not as- } \\
\text { sessed. } \\
\text { Notes: In- } \\
\text { di- } \\
\text { vidual trial } \\
\text { data com- } \\
\text { pared with } \\
\text { pooled ob- } \\
\text { serva- } \\
\text { tional data, } \\
\text { rather than } \\
\text { pooled to- } \\
\text { gether }\end{array}$ \\
\hline Law 1991 & & & $\begin{array}{l}\text { Hyperten- } \\
\text { sive }\end{array}$ & $\begin{array}{l}5 \text { (0.7 to } \\
104) \text { weeks }\end{array}$ & 63 (?) & Not stated & Not stated & Not stated & \\
\hline Law 1991 & & & $\begin{array}{l}\text { The review } \\
\text { estimates } \\
\text { that in } \\
\text { people } \\
\text { aged } 50 \text { - } \\
59 \text { a re- } \\
\text { duction in } \\
50 \mathrm{mmol} \\
\mathrm{Na} / 24 \\
\text { hours } \\
\text { would lead } \\
\text { to a fall of } \\
5 \mathrm{mmHg}\end{array}$ & & & & & & \\
\hline
\end{tabular}


Table 5. Characteristics of systematic reviews on salt and blood pressure (Continued)

\begin{tabular}{|c|c|c|c|c|c|c|c|c|c|}
\hline & & & $\begin{array}{l}\text { in systolic } \\
\text { and } 2 . \\
5 \mathrm{mmHg} \\
\text { in diastolic } \\
\mathrm{BP} \text { in } \\
\text { normoten- } \\
\text { sives, and } \\
\text { a fall of } \\
7 \text { and } 3 . \\
5 \mathrm{mmHg} \\
\text { respec- } \\
\text { tively in } \\
\text { hyperten- } \\
\text { sives }\end{array}$ & & & & & & \\
\hline $\begin{array}{l}\text { Cutler } \\
1997\end{array}$ & $\begin{array}{l}\text { Popula- } \\
\text { tion: adult } \\
\text { human, } \\
\text { Inter- } \\
\text { vention: } \\
\text { sodium } \\
\text { goals } \\
28-273 \\
\text { mmol/ } \\
24 \text { hours, } \\
\text { no con- } \\
\text { founding } \\
\text { allowed, } \\
\text { Outcome: } \\
\text { lab-based } \\
\text { measure } \\
\text { of sodium } \\
\text { intake, } \\
\text { systolic } \\
\text { and/or di- } \\
\text { astolic BP } \\
\text { measured }\end{array}$ & $\begin{array}{l}\text { Yes, ran- } \\
\text { domised } \\
\text { controlled } \\
\text { trials } \\
\text { (crossover } \\
\text { or } \\
\text { parallel de- } \\
\text { sign), pub- } \\
\text { lished only }\end{array}$ & $\begin{array}{l}\text { Nor- } \\
\text { motensive }\end{array}$ & $\begin{array}{l}1 \\
\text { (0.5 to } 36) \\
\text { months }\end{array}$ & 12 (1689) & $\begin{array}{l}\text { Median } \\
-90 \text { (range } \\
16 \text { to } 210)\end{array}$ & $\begin{array}{l}-1.5 \quad(-2.1 \\
\text { to }-1.0)\end{array}$ & $\begin{array}{l}-0.8 \quad(-1.3 \\
\text { to }-0.3)\end{array}$ & $\begin{array}{l}\text { QA: } \\
\text { subgroup- } \\
\text { ing by dou- } \\
\text { ble blind } \\
\text { or not had } \\
\text { no signifi- } \\
\text { cant effect } \\
\text { on overall } \\
\text { outcome. } \\
\text { Notes: re- } \\
\text { gres- } \\
\text { sion analy- } \\
\text { ses used for } \\
\text { publi- } \\
\text { cation bias } \\
\text { failed to re- } \\
\text { ject the } \\
\text { null } \\
\text { hypothesis }\end{array}$ \\
\hline $\begin{array}{l}\text { Cutler } \\
1997\end{array}$ & & & $\begin{array}{l}\text { Hyperten- } \\
\text { sive }\end{array}$ & $\begin{array}{l}2 \quad(1-24) \\
\text { months }\end{array}$ & $22(1043)$ & $\begin{array}{l}\text { Median } \\
-71 \text { (range } \\
27 \text { to } 171 \text { ) }\end{array}$ & $\begin{array}{l}-3.8 \quad(-4.9 \\
\text { to }-2.8)\end{array}$ & $\begin{array}{l}-2.1 \quad(-2.8 \\
\text { to }-1.5)\end{array}$ & \\
\hline Alam 1999 & $\begin{array}{l}\text { Popu- } \\
\text { lation: hu- } \\
\text { man el- } \\
\text { derly (>50 } \\
\text { years), In- } \\
\text { tervention: } \\
\text { changes in } \\
\text { dietary }\end{array}$ & $\begin{array}{l}\text { Yes, pub- } \\
\text { lished En- } \\
\text { glish-lan- } \\
\text { guage ran- } \\
\text { domised } \\
\text { controlled } \\
\text { trials, } \\
\text { crossover }\end{array}$ & $\begin{array}{l}\text { Nor- } \\
\text { motensive } \\
(2 \text { trials) or } \\
\text { with essen- } \\
\text { tial hyper- } \\
\text { tension (9 } \\
\text { trials) }\end{array}$ & $\begin{array}{l}14(9-104) \\
\text { weeks }\end{array}$ & $11(485)$ & $\begin{array}{l}\text { Median } 80 \\
\text { (range } 23 \\
\text { to 260) }\end{array}$ & $\begin{array}{l}-5.6(-6.9 \\
\text { to }-4.3)\end{array}$ & $\begin{array}{l}-3.5(-4.4 \\
\text { to }-2.6)\end{array}$ & $\begin{array}{l}\text { QA: qual- } \\
\text { ity assess- } \\
\text { ment score } \\
\text { tended } \\
\text { to be high } \\
\text { (av- } \\
\text { erage score }\end{array}$ \\
\hline
\end{tabular}


Table 5. Characteristics of systematic reviews on salt and blood pressure (Continued)

\begin{tabular}{|c|c|c|c|c|c|c|c|c|c|}
\hline & $\begin{array}{l}\mathrm{NaCl} \text {, } \\
\text { Outcome: } \\
\text { blood pres- } \\
\text { sure }\end{array}$ & or parallel & & & & & & & $>70 \%)$ \\
\hline $\begin{array}{l}\text { Ebrahim } \\
\text { and Davey } \\
\text { Smith } \\
1998 \text { Ebrahir } \\
\text { and Davey } \\
\text { Smith } \\
1998\end{array}$ & $\begin{array}{l}\text { Popula- } \\
\text { tion: adult } \\
\text { hu- } \\
\text { mans, In- } \\
\text { tervention: } \\
\text { dietary } \\
\text { sodium re- } \\
\text { duction vs. } \\
\text { con- } \\
\text { trol, Out- } \\
\text { come: di- } \\
\text { astolic and } \\
\text { systolic BP } \\
\text { measure- } \\
\text { ment, uri- } \\
\text { nary } \\
\text { sodium ex- } \\
\text { cretion }\end{array}$ & $\begin{array}{l}\text { Yes, ran- } \\
\text { domised } \\
\text { controlled } \\
\text { trials of at } \\
\text { least } \\
6 \text { months } \\
\text { duration }\end{array}$ & $\begin{array}{l}\text { Nor- } \\
\text { motensive }\end{array}$ & Not stated & $2(1095)$ & Not stated & $\begin{array}{l}-1.3 \quad(-2.7 \\
\text { to }+0.1)\end{array}$ & $\begin{array}{l}-0.8 \quad(-1.8 \\
\text { to }+0.2)\end{array}$ & $\begin{array}{l}\text { QA: Qual- } \\
\text { ity not as- } \\
\text { sessed. }\end{array}$ \\
\hline $\begin{array}{l}\text { Ebrahim } \\
\text { and Davey } \\
\text { Smith } \\
1998\end{array}$ & & & $\begin{array}{l}\text { Hyperten- } \\
\text { sive }\end{array}$ & Not stated & $6(466)$ & Not stated & $\begin{array}{l}-2.9(-5.8 \\
\text { to } 0.0)\end{array}$ & $\begin{array}{l}-2.1 \quad(-4.0 \\
\text { to }-0.1)\end{array}$ & \\
\hline $\begin{array}{l}\text { This } \\
\text { review, } 6 \text { to } \\
12 \text { months }\end{array}$ & $\begin{array}{l}\text { Popula- } \\
\text { tion: adult } \\
\text { human, } \\
\text { Inter- } \\
\text { vention: } \\
\text { sodium } \\
\text { reduced } \\
\text { diet vs. } \\
\text { usual diet, } \\
\text { Outcome: } \\
\text { urinary } \\
\text { sodium } \\
\text { excretion, } \\
\text { systolic } \\
\text { and/or } \\
\text { diastolic } \\
\text { BP mea- } \\
\text { surements } \\
\text { taken } 6 \text { to } \\
12 \text { months }\end{array}$ & $\begin{array}{l}\text { Yes, paral- } \\
\text { lel ran- } \\
\text { domised } \\
\text { controlled } \\
\text { trials }\end{array}$ & $\begin{array}{l}\text { Nor- } \\
\text { motensive }\end{array}$ & $\begin{array}{l}6 \text { (6 to } 12) \\
\text { months }\end{array}$ & $3(2124)$ & $\begin{array}{l}\text { Weighted } \\
\text { mean } 43 \\
(95 \% \quad \text { CI } \\
16 \text { to } 70)\end{array}$ & $\begin{array}{l}-2.3(-3.1 \\
\text { to }-1.6)\end{array}$ & $\begin{array}{l}-1.2(-1.8 \\
\text { to }-0.6)\end{array}$ & $\begin{array}{l}\text { QA: Sensi- } \\
\text { tivity anal- } \\
\text { y- } \\
\text { sis (remov- } \\
\text { ing trials } \\
\text { where allo- } \\
\text { cation con- } \\
\text { cealment is } \\
\text { poor } \\
\text { or unclear) } \\
\text { had no ef- } \\
\text { fect on di- } \\
\text { rection or } \\
\text { signifi- } \\
\text { cance of re- } \\
\text { sults }\end{array}$ \\
\hline
\end{tabular}


Table 5. Characteristics of systematic reviews on salt and blood pressure (Continued)

\begin{tabular}{|c|c|c|c|c|c|c|c|}
\hline & $\begin{array}{l}\text { or more } \\
\text { than } 12 \\
\text { months } \\
\text { after inter- } \\
\text { vention }\end{array}$ & & & & & & \\
\hline $\begin{array}{l}\text { This } \\
\text { review, } 6 \text { to } \\
12 \text { months }\end{array}$ & & $\begin{array}{l}\text { Hyperten- } \\
\text { sive }\end{array}$ & $\begin{array}{l}12 \\
(12 \text { to } 12) \\
\text { months }\end{array}$ & $4(179)$ & $\begin{array}{l}\text { weighted } \\
\text { mean } 48 \\
(95 \% \quad \text { CI } \\
33 \text { to } 63)\end{array}$ & $\begin{array}{l}-8.0(-15.8 \\
\text { to }-0.2)\end{array}$ & $\begin{array}{l}-4.5 \quad(-8.7 \\
\text { to }-0.4)\end{array}$ \\
\hline $\begin{array}{l}\text { This re- } \\
\text { view, } 13 \text { to } \\
60 \text { months }\end{array}$ & & $\begin{array}{l}\text { Nor- } \\
\text { motensive }\end{array}$ & $\begin{array}{l}36 \\
(18 \text { to } 36) \\
\text { months }\end{array}$ & $3(2285)$ & $\begin{array}{l}\text { weighted } \\
\text { mean } 34 \\
(95 \% \quad \text { CI } \\
19 \text { to } 50)\end{array}$ & $\begin{array}{l}-1.1(-1.9 \\
\text { to }-0.3)\end{array}$ & $\begin{array}{l}-0.5 \quad(-1.1 \\
\text { to } 0.0)\end{array}$ \\
\hline $\begin{array}{l}\text { This re- } \\
\text { view, } 13 \text { to } \\
60 \text { months }\end{array}$ & & $\begin{array}{l}\text { Hyperten- } \\
\text { sive }\end{array}$ & 24 months & $1(62)$ & $\begin{array}{l}\text { weighted } \\
\text { mean } 40 \\
(95 \% \quad \text { CI } \\
22 \text { to } 57)\end{array}$ & $\begin{array}{l}-1.5(-12.6 \\
\text { to } 9.6)\end{array}$ & $\begin{array}{l}-7.0(-12.5 \\
\text { to }-1.5)\end{array}$ \\
\hline
\end{tabular}

\section{F E E D B A C K}

\section{Comments on the Cochrane Review by Hooper et al}

\section{Summary}

Previous meta-analyses have lumped both short term and long term trials together [1,2] and therefore Hooper et al's meta-analysis is an important attempt to look at whether longer term salt reduction (i.e. more than 6 months) in randomised trials causes a fall in blood pressure $[3,4]$.

Given the inherent difficulty of reducing salt intake long term, it is not surprising that they only found a small reduction of $2 \mathrm{~g} /$ day in the long-term trials from an intake of around $10 \mathrm{~g} /$ day. This contrasts with a recommended reduction in nearly all western countries of at least 5 to $6 \mathrm{~g}$ /day from the now almost universal intake of 10 to $12 \mathrm{~g} /$ day. It would come, therefore, as no surprise that a small reduction ( $2 \mathrm{~g} /$ day) in salt intake compared to the public health recommended reduction only causes a small, but in their metaanalysis, a highly significant reduction in blood pressure. Nevertheless, this small reduction in adult population blood pressure would be expected to have a significant effect on reducing strokes, heart attacks [5,6], and heart failure, the commonest causes of death and disability in the western world.

There are important points, which Hooper et al fail to mention in the discussion section of their paper. For instance, other metaanalyses have demonstrated a dose response to salt restriction [7]. Therefore, if it was possible to reduce salt intake by a larger amount (e.g. by reducing the salt content of processed food) the fall in blood pressure and the benefits would be even larger.

There are errors and misquotation of the relevant literature in the meta-analysis. They claim that interventions used were highly intensive, but the majority of studies gave no details as to what advice was offered. The fact that very few of these studies were successful in reducing salt intake more than 1 or $2 \mathrm{~g}$ /day casts further doubt on this unwarranted assertion. Furthermore, as the majority of salt comes from processed foods, it is absolutely vital to provide processed foods with less salt in these studies. Unfortunately, only a few of the studies that they included provided reduced salt foods.

In the meta-analysis, the follow up study of the TOHP trial [8] was included as an over 60 months intervention trial, but salt intake was in fact only reduced for 18 months, after which all participants returned to their normal diet. It is not, therefore, as Hooper et al state, a 60 -month trial of salt restriction.

Advice to reduce dietary salt for prevention of cardiovascular disease (Review)

Copyright () 2009 The Cochrane Collaboration. Published by John Wiley \& Sons, Ltd. 
Alderman claimed that reducing salt intake in treated hypertensives led to myocardial infarction [9]. Detailed examination of the paper and analysis of the urinary creatinines that were provided later clearly demonstrated that the group on the low salt intake were in fact there because most of them had collected an inadequate 24 hour urine and therefore had less salt in the urine as it was an incomplete urine collection. There was no evidence that they were on a lower salt intake. Furthermore, there was only one 24 hour urine at the time of entry and no further measurements were made during the study, so the study suffered from the defect that there was no evidence that the group who were said to have been on a lower salt intake were in fact on a lower salt intake at entry and no attempt was made to measure salt intake during the rest of the study. In the second study [10] taken from the NHANES-1 Dietary Survey, the First National Health and Nutrition Examination survey in the USA, no assessment of discretionary salt (salt added to the table and cooking) was made. As the study was conducted in the 1980s, at this time approximately half of all salt intake would be in the form of discretionary salt. Therefore the assessment of total dietary salt intake is likely inadequate. Those on a lower salt intake were on a calorie intake that was equivalent to a starvation diet and yet were heavier than those who were said to be on a higher salt intake, in spite of the fact that these latter people had a much higher calorie intake. These two studies $[9,10]$ cannot be quoted as evidence about the long-term cardiovascular effects of salt reduction. We suggest reading correspondence following these papers [11-16].

Hooper et al's meta-analysis has been previously published in the British Medical Journal [4]. It appears that their current Cochrane review has not been altered and, in particular, no attempt has been made to respond to criticism raised at the time $[17,18]$. For instance, Hooper et al claim that an increase in cholesterol occurs with salt restriction and quoted the meta-analysis by Graudal et al [2]. The latter meta-analysis included trials of very short term, mainly for only 5 days, and large changes in salt intake, e.g. $20 \mathrm{~g} / \mathrm{day}$. With these acute large changes in salt intake there are large changes in blood volume and it is not surprising that in the short term there is a change in cholesterol. However, it has been well demonstrated in longer-term trials of more modest reductions in salt intake that there is no change in cholesterol [7].

In spite of these problems with their meta-analysis, we agree with the conclusions that if salt intake is reduced by small amounts there are small but significant reductions in blood pressure. Indeed, these blood pressure falls fit almost exactly with the dose response that we found in a more recent meta-analysis of salt reduction [7].

In our opinion the conclusion from their study should read: "A meta-analysis of randomised longer term salt reduction trials has shown the difficulty of reducing salt intake in the long term without the provision of processed foods with less salt, as the mean salt reduction in the studies was only $2 \mathrm{~g}$ /day. Nevertheless, this small reduction in salt intake did cause a significant fall in blood pressure, which, on a population basis, would lead to a significant reduction in strokes, heart attacks and heart failure. Therefore, even small reductions in salt intake would be very worthwhile and in developed countries are practical to carry out. There is no evidence that this small reduction in salt intake would have any harmful effect. It could easily be implemented by the food industry in a very short time as it would only mean a 15 to $20 \%$ reduction in the salt content of all processed, canteen, restaurant and fast foods. This reduction in salt concentration of foods is not detectable and can easily be achieved, as shown by the experience of a leading supermarket in the UK where such reductions have already been implemented. If larger reductions in salt intake could be implemented in the population the benefits would be large". Indeed, the authors' own press release states that the difficulty for people to reduce their salt intake is "because most salt comes from processed and ready made foods. Efforts by the government to reduce hidden salt in foods such as bread and cereals may be more effective as no dietary change is necessary" [19].

References

1. Midgley JP, Matthew AG, Greenwood CM, Logan AG. Effect of reduced dietary sodium on blood pressure: a meta-analysis of randomised controlled trials. JAMA 1996;275:1590-1597.

2. Graudal NA, Galloe AM, Garred P. Effect of sodium restriction on blood pressure, renin, aldosterone, catecholamines, cholesterols, and triglyceride: a meta-analysis. JAMA 1998;279:1383-91.

3. Hooper L, Bartlett C, Davey Smith G, Ebrahim S. Reduced dietary salt for prevention of cardiovascular disease (Cochrane Review). In: The Cochrane Library, Issue 1, 2003. Oxford: Update Software.

4. Hooper L, Bartlett C, Davey Smith G, Ebrahim S. Systematic review of long term effects of advice to reduce dietary salt in adults. BMJ 2002; 325: 628-634.

5. Prospective studies collaboration. Age-specific relevance of usual blood pressure to vascular mortality: a meta-analysis of individual data for one million adults in 61 prospective studies. Lancet 2002;360:1903-13.

6. Murray CJL, Lauer JA, Hutubessy RCW, Niessen L, Tomijima N, Rodgers A, Lawes CMM, Evans DB. Effectiveness and costs of interventions to lower systolic blood pressure and cholesterol: a global and regional analysis on reduction of cardiovascular-disease risk. Lancet 2003;361:717-25.

7. He FJ, MacGregor GA. Effect of modest salt reduction on blood pressure. A meta-analysis of randomised trials. Implications for public health. J Hum Hypertens 2002;16:761-770.

8. He J, Whelton PK, Appel LJ, Charleston J, Klag MJ. Long-term effects of weight loss and dietary sodium reduction on incidence of hypertension. Hypertension 2000; 35: 544-550.

Advice to reduce dietary salt for prevention of cardiovascular disease (Review) 
9. Alderman MH, Madhaven S, Cohen H, Sealey JE, Laragh JH. Low urinary sodium is associated with greater risk of myocardial infarction among treated hypertensive men. Hypertension 1995;25:1144-1152.

10. Alderman MH, Cohen H, Madhaven S. Dietary sodium intake and mortality. The National Health and Nutrition Examination Survey (NHANES 1). Lancet 1998;351:781-785.

11. MacGregor G. Low urinary sodium and myocardial infarction. Letter. Hypertension 1996;27:156.

12. de Wardener H. Salt reduction and cardiovascular risk: the anatomy of a myth. J Human Hypertens 1999;13:1-4.

13. de Wardener H, MacGregor GA. Sodium intake and mortality. Letter. Lancet 1998;351:1508.

14. Engelman K. Sodium intake and mortality. Letter. Lancet 1998;351:1508.

15. Karppanen H, Mervaala E. Sodium intake and mortality. Letter. Lancet 1998;351:1509.

16. MacGregor GA, de Wardener HE. Salt, blood pressure and health. Int J Epidemiol 2002;31:320-7.

17. MacGregor GA, He FJ, Perry IJ, Law MR, Wald NJ, Hooper L, Bartlett C, Davey Smith G, and Ebrahim S. Long term effects of advice to reduce dietary salt. BMJ 2003;326:222-4.

18. MacGregor GA, He FJ. Salt - Misleading Front Cover and Letter. http://bmj.com/cgi/eletters/326/7382/222/a\#29301.

19. New ways of reducing salt intake needed to make a long-term impact on blood pressure. Media release. University of Bristol. http: //bris.ac.uk/Depts/Info-Office/news/archive/salt.htm .

\section{Reply}

The Authors Reply:

The stated objective was to assess the long-term effects of advice to restrict dietary sodium, rather than the effect of the actual sodium restriction (as advice is rarely followed perfectly and over a long period of time). The effect of such advice is important as it is commonly used in primary care and is a central part of the guidelines produced by bodies such as the British Hypertension Society [1].

Despite the difficulties inherent in reducing sodium intake, individual advice does result in a significant but small reduction in blood pressure. If this small reduction could be achieved across entire populations, it would be reasonable to expect some benefits in terms of cardiovascular disease events avoided. But it is simply unrealistic to imagine that interventions as intensive as those used in the trials reviewed here could be applied population wide.

Of the 2349 people involved in the studies which measured blood pressure at 13 to 60 months (see forest plot 02, 02), 2287 had been involved in intensive and comprehensive behavioural change program to help them reduce their salt intake (for the 6 to 12 month outcome period 2124 of 2303 had intensive interventions, forest plot 02, 01). As an example, the least intensive of these programs, the HPT study, included group sessions (17 sessions over the first year, 28 over 3 years) with individual counselling if sessions were missed, a newsletter between sessions, self assessment, goal setting, a participant manual, a food counter, cookbook, food demonstrations and tastings, team building exercises and tokens of accomplishment, led by personnel trained and experienced in effecting behaviour change related to food. This type of intervention is not realistic at a population level.

Meta-analyses have only been able to demonstrate a dose response of blood pressure to sodium reduction when they have artificially forced the regression line through the origin. Where this has not been done no dose response has been seen.

See comments above on intensity of dietary advice. While several small trials were included with little information on how or what advice was provided, the majority of people involved in trials (who provided the bulk of the information on blood pressure response after 1 year) were in the larger, well documented trials with intensive interventions.

A different meta-analysis is required to assess the effect of interventions where large quantities of low sodium foods are provided to participants - this would be an unusual addition to dietary advice in primary or secondary care, but is a valid and interesting question in its own right.

These issues regarding the TOHP trial are already discussed within the results section of the review (paragraph 4).

The two cohort studies mentioned by He and MacGregor are not included in the review, but are mentioned very briefly in the discussion. The section states that a weakness of our review is its lack of ability to assess the effect of advice to reduce sodium on cardiovascular morbidity and mortality. Six cohort studies are quoted, and show a variety of conclusions about the effects of salt on death and cardiovascular health. The point being made is that we cannot be entirely sure that a reduction in blood pressure through advice to reduce salt intake will result in only beneficial effects on health. Ideally we would have some direct evidence that health benefits accrue.

Clearly, also, the cohort studies have large potential flaws, which make reliance on their conclusions unhelpful. Randomised controlled trials, and systematic reviews of randomised controlled trials are needed to understand the health effects of changes in diet.

In Graudal's review [2] 653 participants were involved in the meta-analysis which showed a significant increase in total cholesterol after around 7 days of a low sodium diet (and 517 participants were involved in the significant increase in LDL at 7 days). In the quoted review by He and MacGregor [7] only three trials contribute information on total cholesterol (81 participants) and fewer on

Advice to reduce dietary salt for prevention of cardiovascular disease (Review)

Copyright @ 2009 The Cochrane Collaboration. Published by John Wiley \& Sons, Ltd. 
LDL. It would be extremely surprising if this number of participants did show a significant effect on total cholesterol or LDL. In this circumstance lack of a significant effect does not rule out a clinically important effect of salt reduction on lipids in the longer term. We disagree with the conclusions proposed by He and MacGregor; we did not assess palatability of processed food, or detectability of a $20 \%$ salt reduction in such foods. We cannot be certain from our review what the health effects of a general reduction in sodium might be. We stand by our conclusions as stated in the review.

References:

1. Ramsay LE, Williams B, Johnston GD, MacGregor GA, Poston L, Potter JF et al. Guidelines for management of hypertension: report of the third working party of the British Hypertension Society. Journal of Human Hypertension 1999;13:569-92.

\section{Contributors}

Feng J. He Cardiovascular Research Fellow

Blood Pressure Unit, St. George's Hospital Medical School, Cranmer Terrace, London SW17 0RE

Graham A. MacGregor Professor of Cardiovascular Medicine

Blood Pressure Unit, St. George's Hospital Medical School, Cranmer Terrace, London SW17 0RE. Tel: 020-8725 2989. Fax: 020-

8725 2959. E-mail: g.macgregor@sghms.ac.uk

\section{Comments on the Review by Hooper et al}

\section{Summary}

Health care providers, researchers and policy makers need systematic reviews for rational decision making, because they are inundated with otherwise unmanageable amounts of information [1]. It follows that the title and the Reviewers' Conclusions on the front page constitute critical elements of a Cochrane Review.

In the Review by Hooper et al [2] we find both the title and conclusions misleading. This is especially regrettable since both the title and the conclusions were clear and informative in their earlier BMJ version of the same meta-analysis [3].

Their BMJ paper is entitled 'Systematic review of long-term effects of advice to reduce dietary salt in adults' and their conclusion is that the 11 trials 'provided only small reductions in blood pressure and sodium excretion'. Thus the BMJ paper clearly refers to a metaanalysis of studies of effectiveness (a measure of the extent to which an intervention has its intended effect) in which the outcome was limited by poor dietary compliance, rather than efficacy (a measure of what can be achieved when an intervention is fully implemented). Effectiveness is measured by the outcome of offering a treatment or other intervention to people who are free to accept or reject it, as they might ordinarily do [4], complying only as well as their personal inclination and social or economic circumstances allow. Efficacy is measured from the outcome when a specified treatment or other intervention is fully applied [4].

The title of the Cochrane Review no longer makes this distinction clear. The title this time is 'Reduced dietary salt for prevention of cardiovascular disease' and the conclusion is that 11 long-term trials provided 'only minimal reductions in blood pressure'. Hence, both the title and conclusion ignore the fact that the degree of dietary sodium reduction achieved in these trials was only modest, thereby limiting the effectiveness of the intervention. Their Cochrane Review implies that these authors are publishing a finding about efficacy and concludes that low salt diets are not very efficacious, which is untrue - significant reductions in blood pressure can be achieved in both hypertensives and normotensives when the dietary intervention is more fully applied, as it was in the short DASH Sodium study in which all of the food was supplied by the study organisers [5] and in longer studies where it was also more fully applied [6]. A Cochrane Review that misrepresents limited effectiveness as limited efficacy is seriously misleading to policy makers expecting guidance, and it limits the value of the Cochrane Collaboration - the very institution that commemorates the late Archie Cochrane, who made effectiveness a standard term in epidemiology [7,8]. The correspondence after their BMJ paper drew attention to good evidence of the efficacy of a lower salt intake, and the important implication for policy makers that a better supply of suitable foods will improve dietary compliance and effectiveness [9].

We discuss the fallacy of confusing effectiveness with efficacy at greater length in our comments on the Cochrane Review by Jürgens and Graudal [10].

Call for long-term randomised controlled trials

The authors conclude that we need long-term randomised controlled trials (RCTs) of a lower salt intake of a size and duration that will enable us to measure mortality and morbidity outcomes. It is unrealistic to call for such trials without suggesting ways of removing the fatal obstacles. Some of these have already been published [11], but the recommendations of JNC 7 have raised new obstacles that we consider insurmountable.

Advice to reduce dietary salt for prevention of cardiovascular disease (Review) 
After reviewing no less than 11 inconclusive long-term effectiveness trials, Hooper et al have given no reasons for believing that the proposed long-term RCT would provide anything but yet another inconclusive effectiveness trial. The alternative of a long-term efficacy trial would explode the budget with the astronomical cost of catering for all the meals eaten throughout the day by thousands of people for one to three decades.

Moreover JNC 7 has added a new obstacle. It gave high-normal blood pressure a new name - prehypertension - for which JNC 7 has advocated nonpharmacological treatment, including the low salt diet of the intervention group [12]. This means the trial could recruit only subjects with blood pressure (BP) below 120/80, because it would be unethical to randomise subjects with prehypertension to the control group, postponing the expected late endpoints for perhaps another decade or more.

Secondly for ethical reasons it would be mandatory to give all members of the control group treatment for prehypertension as soon as their BP rose above 120/80, which would mean their having to adopt the low salt diet of the intervention group. This would result in the gradual (and probably near-complete) erosion of the control group as members leave on account of the rise of BP with age that would have provided the difference in long-term endpoints.

In our view the long-term RCT was never feasible because the ethical requirement to keep the BP of all members of the control group permanently $<140 / 90$ as soon as they became hypertensive would have greatly postponed the expected late endpoints. The new ethical requirement to treat prehypertension by allowing the control group member to share the diet of the diet group is in our view an insurmountable obstacle.

What would Cochrane's advice be today? It is easy to predict from his writings what he might have said and done. Cochrane knew that RCTs are unable to answer a large number of very important questions in public health, on account of practical, ethical, economic or other obstacles [8]. Cochrane would obtain other evidence. Some of that evidence might be observation and inference and as much as possible would be experimental. Our belief is that the existing evidence would allow Cochrane to approve of government initiatives to achieve the $50 \%$ reduction in the sodium content of processed foods that the American Public Health Association has called for (with explicit support from JNC 7).

References

1. Hooper L, Bartlett C, Davey Smith G, Ebrahim S. Reduced dietary salt for prevention of cardiovascular disease (Cochrane Review), In: The Cochrane Library, Issue 1, 2003. Oxford: Update Software. Oxford: Update Software; 2003.

2. Mulrow CD. Rationale for systematic reviews. In: Chalmers I, Altman D G. Systematic Reviews. London: BMJ Publishing Group; 1995:1.

3. Hooper L, Bartlett C, Davey Smith G, Ebrahim S. Systematic review of long-term effects of advice to reduce dietary salt in adults. BMJ 2002;325:628-32.

4. Fletcher RH, Fletcher SW, Wagner EH. Clinical Epidemiology: the essentials (2nd edn). Baltimore: Williams \& Wilkins; 1988:13233.

5. Sacks FM, Svetkey LP, Vollmer WM, Appel LJ, Bray GA, Harsha D, et al. Effects on blood pressure of reduced dietary sodium and the Dietary Approaches to Stop Hypertension (DASH) diet. N Engl J Med 2001;344:3-10.

6. MacGregor GA, Markandu ND, Sagnella GA, Singer DRJ, Cappuccio FP. Double-blind study of three sodium intakes and longterm effects of sodium restriction in essential hypertension. Lancet 1989;2:1244-47.

7. Last JM. A dictionary of epidemiology, 3rd edition. Oxford: Oxford University Press; 1995:52.

8. Cochrane AL. Effectiveness and efficiency: random reflections on health services. London: The Nuffield Provincial Hospitals Trust; 1972.

9. Law MR, Wald NJ. Salt needs to be reduced in manufacturing and processing food [letter]. BMJ 2003;326:223-24.

10. Jürgens G, Graudal NA. Effects of a low sodium diet versus high sodium diet on blood pressure, renin, aldosterone, catecholamines, cholesterols, and triglyceride (Cochrane Review). In: The Cochrane Library, Issue 1. Oxford: Update Software; 2003.

11. Chobanian AV, Hill M. National Heart, Lung, and Blood Institute Workshop on sodium and blood pressure: a critical review of current scientific evidence. Hypertension 2000;35:858-63.

12. Joint National Committee. The seventh report of the Joint National Committee on Prevention, Detection, Evaluation, and Treatment of High Blood Pressure. JAMA 2003;289:2560-72.

\section{Reply}

The Authors Reply:

"Reduced dietary salt for prevention of cardiovascular disease" is an appropriate title for a Cochrane review as it follows the recommended format of "intervention for disease". The title is not declarative and it is necessary for the reader to examine the abstract for the objectives, which make it totally clear that we are assessing the effect of dietary advice. However, after consultation with the Co-ordinating Editor of the Cochrane Hypertension Group, we have altered the title to 'Advice to reduce dietary salt for prevention of cardiovascular disease'.

Advice to reduce dietary salt for prevention of cardiovascular disease (Review) 
The data cited which 'offers good evidence of the efficacy of a lower salt intake' is the following:

Reducing the current average salt consumption in Britain by $3 \mathrm{~g} /$ day (about one third) would reduce average blood pressure by about 5 $\mathrm{mm} \mathrm{Hg}$ systolic in people over 50 and thereby reduce the incidence of heart attack and strokes by about $15 \%$ and $22 \%$ respectively.[1] A reduction of $6 \mathrm{~g}$ /day would reduce blood pressure by about twice as much with a corresponding additional reduction in the incidence of heart attacks and stroke. Reducing salt intake generally would thus have a major impact in the prevention of cardiovascular disease. Law's study from which this information is derived used a very unique methodology. Instead of pooling randomised controlled trials (and there are many reviews that do, see additional table 05), observational studies were pooled and were then compared with the results of the controlled trials (most of which were not randomised) and determines that they are not significantly dissimilar. In doing this he comes up with an effect size of a very different order than all other published systematic reviews. This is not a credible way to pool trial evidence. We drew attention to this in our response to the criticisms of our BMJ review.[2]

The estimate of the effect that this would have on mortality and morbidity was taken from evidence from a prospective study, but different prospective studies come up with very different relationships to mortality and morbidity (see discussion section of this review). It is not reasonable to pick only the evidence that supports the most optimistic view.

To assess the effect of dietary advice to reduce salt intake on cardiovascular morbidity is not necessarily difficult. Of the four large trials included in this review (those including at least 250 participants) information on cardiovascular morbidity that could be used in metaanalysis was provided by only one (TONE [3]). If details were published of the 'in study' cardiovascular morbidity for the other three (a further 2326 participants) this would be likely to provide a reasonable amount of extra information (and if the protective trend of low salt advice seen in the TONE trial was followed we may even see statistically significant protection from cardiovascular events in the low salt advice group). We did try to contact the trialists for this data but received no replies.

Although it might be argued that these trials have now been completed, long-term follow up of trial participants who received intensive dietary advice, the effects of which might reasonably be expected to induce life-long behaviour change, may be informative. However, to check the validity of such long-term evaluations, both the extent of dietary salt reduction advice provided to the control groups at the close of the studies, or since, and the maintenance of lower salt intake among the intervention groups does need to be assessed.

These are the logical first inexpensive steps to take. If these are not enough, then, a new (and large) trial of dietary advice should be contemplated. Investigators of cholesterol-lowering by either diet or drugs were not thwarted by the scale of trials necessary to demonstrate convincing effects.

The most important point is that trialists of dietary advice have failed to contribute relevant data to the public domain, and, as we found were unwilling to enter into data sharing with systematic reviewers. Perhaps the challenge is for trialists in this area to form collaboration with the aim of conducting an individual patient data meta-analysis. It should be noted we have never advocated a longterm efficacy trial.

The ethical issues inherent in any trial depend on the degree of clinical equipoise and as the salt debate illustrates, extreme views are held which makes it likely that sufficient clinicians in equipoise would be found. With ever-lower levels of "normal" blood pressure being defined it will be necessary to advance the knowledge base by conducting further trials.

What Archie Cochrane would have decided to do in these circumstances is a matter of speculation and of little relevance to the current issues. The importance of government initiatives to reduce sodium in processed foods depends on the efficacy, rather than effectiveness, of salt reduction and the DASH [4] salt study has leant serious weight to the importance of salt reduction to reduce blood pressure, but also of diets with increased fruit and vegetable intake, reduction in saturated fats, adequate whole grains, calcium, protein etc. This probably cannot all be achieved from processed foods, however low in salt they may be.

We stand by the conclusions as stated in the review.

References:

1. Law MR, Frost CD, Wald NJ. By how much does dietary salt reduction lower blood pressure? III--Analysis of data from trials of salt reduction. BMJ. 1991;302:819-24.

2. Hooper L, Bartlett C, Davey Smith G, Ebrahim S. Long term effects of advice to reduce dietary salt (authors reply). BMJ 2003;326: 224.

3. Whelton PK, Appel LJ, Espeland MA, Applegate WB, Ettinger-WH J, Kostis JB et al. Sodium reduction and weight loss in the treatment of hypertension in older persons: a randomized controlled trial of nonpharmacologic interventions in the elderly (TONE). TONE Collaborative Research Group. JAMA 1998;279:839-46.

4. Sacks FM, Svetkey LP, Vollmer WM, Appel LJ, Bray GA, Harsha D et al. Effects on blood pressure of reduced dietary sodium and the Dietary Approaches to Stop Hypertension (DASH) diet. New England Journal of Medicine 2001;344:3-10.

\section{Contributors}

Trevor C Beard

Advice to reduce dietary salt for prevention of cardiovascular disease (Review)

Copyright () 2009 The Cochrane Collaboration. Published by John Wiley \& Sons, Ltd. 
Senior Research Fellow

Menzies Centre for Population Health Research

University of Tasmania, Hobart, Tasmania 7001, Australia

trevor.beard@utas.edu.au

Michael Stowasser

Senior Lecturer

University of Queensland Department of Medicine

Princess Alexandra Hospital, Brisbane, Queensland 4102, Australia

m.stowasser@uq.edu.au

\section{WHAT'S NEW}

Last assessed as up-to-date: 25 November 2003.

\begin{tabular}{lll}
\hline Date & Event & Description \\
\hline 12 November 2008 & Amended & Contact details updated \\
\hline
\end{tabular}

\section{H I S T O R Y}

Protocol first published: Issue 2, 2002

Review first published: Issue 1, 2003

\begin{tabular}{|c|c|c|}
\hline Date & Event & Description \\
\hline 13 August 2008 & Amended & Converted to new review format. \\
\hline 26 May 2004 & Amended & $\begin{array}{l}\text { Correlations used to estimate the standard deviations } \\
\text { of change in diastolic blood pressure from baseline } \\
\text { to } 6-12 \text { months were incorrect. These correlations are } \\
\text { now not used for diastolic blood pressure. This alters } \\
\text { the meta-analysis pooling of the effect on salt reduc- } \\
\text { tion advice compared with control on diastolic blood } \\
\text { pressure at } 6-12 \text { months from }-1.2 \mathrm{mmHg}(95 \% \mathrm{CI}- \\
1.8 \text { to }-0.7) \text { to }-1.2 \mathrm{mmHg}(95 \% \mathrm{CI}-1.8 \text { to }-0.6)\end{array}$ \\
\hline 26 November 2003 & $\begin{array}{l}\text { New citation required but conclusions have not } \\
\text { changed }\end{array}$ & $\begin{array}{l}\text { Substantive amendment. } \\
\text { Title of the review changed to "Advice to reduce dietary } \\
\text { salt for prevention of cardiovascular disease" } \\
\text { Comments and criticisms by Beard \& Stowasser and } \\
\text { by He and MacGregor were added, as well as authors' } \\
\text { replies to the comments and criticisms }\end{array}$ \\
\hline
\end{tabular}




\section{CONTRIBUTIONSOFAUTHORS}

All authors were actively involved in the design of the review, checking the data and provision of critical revisions to the manuscript, which was drafted by LH. LH and CB independently searched, decided on trial inclusion/exclusion, extracted data and assessed study quality. LH, CB and SE performed and duplicated the statistical analyses, SE and GDS were primary advisors guiding and interpreting the review. $\mathrm{LH}$ is the guarantor.

\section{DECLARATIONSOF INTEREST}

None of the reviewers have ever received funding in any form from food or beverage industries or anti-salt lobby groups. LH owned 285 shares in the West Indies Rum Distillery Ltd, Barbados at the time of completing the review.

\section{SOURCES OF SUPPORT}

\section{Internal sources}

- University of Manchester, UK.

- Central Manchester and Manchester Children's University Hospitals NHS Trust, UK.

\section{External sources}

- North West Research and Development Training Fellowship (LH), UK.

\section{INDEX TERMS}

\section{Medical Subject Headings (MeSH)}

Antihypertensive Agents [therapeutic use]; Cardiovascular Diseases [* prevention \& control]; Diet, Sodium-Restricted; Hypertension [*diet therapy; drug therapy]; Randomized Controlled Trials as Topic; Sodium Chloride, Dietary [*administration $\&$ dosage]

\section{MeSH check words}

Humans 